\title{
نLas.us
}
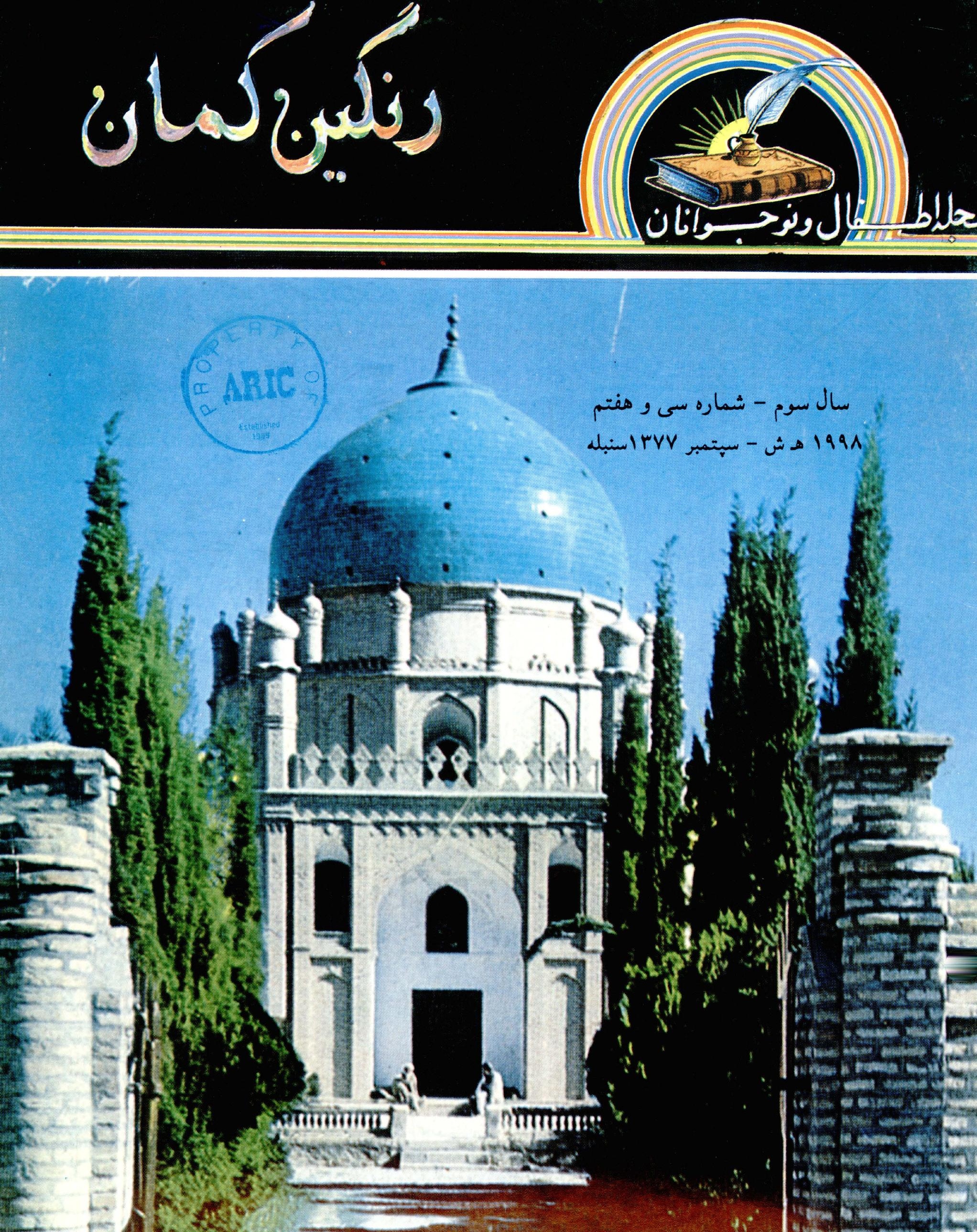


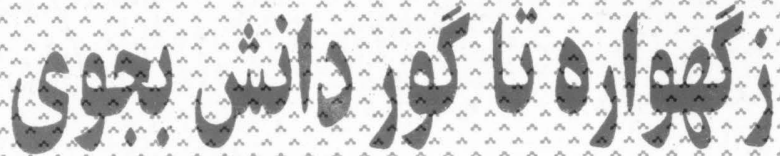

\section{فبوى مليث}

ancono

دعلم زده كوونسكى مسنكي له

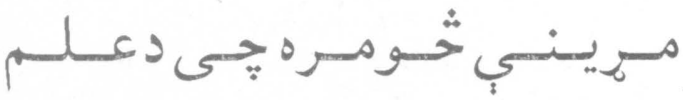

دحاصلولو يِه لاره كى زيار باسى

هغومره كَتْه ترلاسه كوي.

\section{ضرورت اوليه}

كفته اند: ضروريات اوليهء انسانها

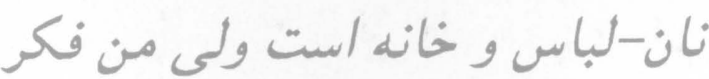
ميكنم صلح و آرمش نيز از جمله ولهي ضرورتهاى اوليه ميباشد.

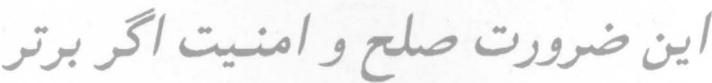

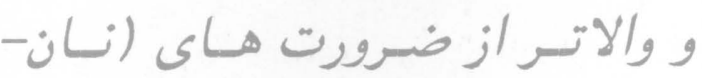
لباس - خانه) نباشد. كمتر از آنها نيز نمى تواند باشد.

زيرا در فضاى صلح آميز است كه باند

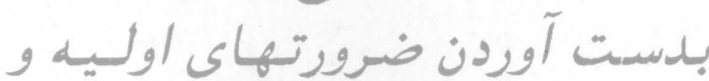
استفادهء بهتر از آنها ميسر است و وليهاو
ونكيومان

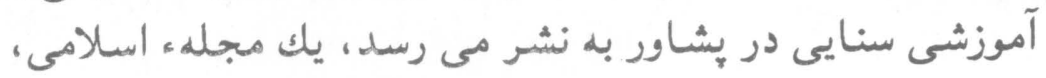

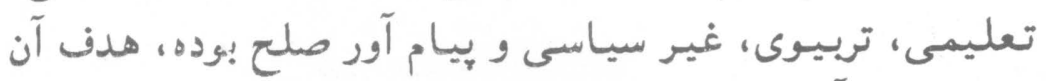

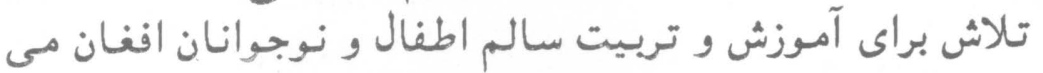

باشد.

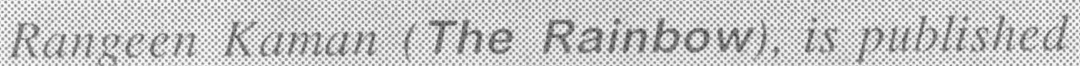

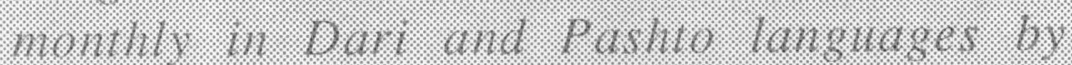

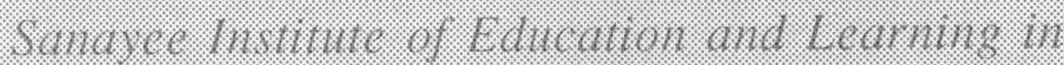

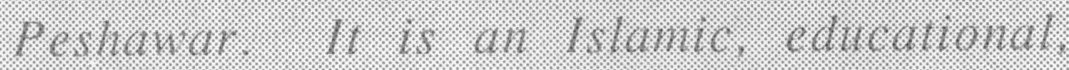

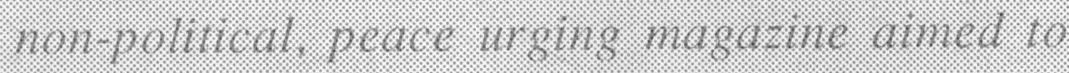

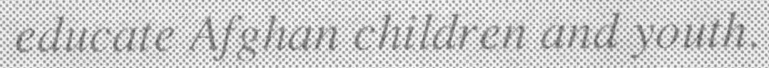

مجله اطنال و نوجرانان

مؤسبس راز مسحمد دوليلى

هيئت تحرير

تحت نظر

انستيتيوت تعليسى و آموزشى سنايى "سيالي"

صاحب امتياز

$$
\text { محمد كبير "كاووسى" }
$$

مهتمبم

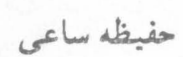

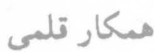

امام الدين - ماعن

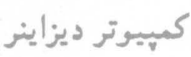

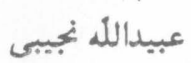

بستنگ

IrVY

سال تأسبيس

انستيتيوت تعليمى و آموزشى سنايى " سبال"

آدرس يشاور

اوركزي بلازه جوك يونيورستى تاون، يشاور - بياكستان

$$
\begin{aligned}
& +9 r+91 \text { - AErVOO } \\
& +9 r+91 \text { - AEr } 100
\end{aligned}
$$$$
\text { تيليفون نمبر }
$$

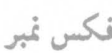

E-mail :dalili@sieal.pwr.sdnpk.undp.org.

$$
\text { ( ع.... }
$$




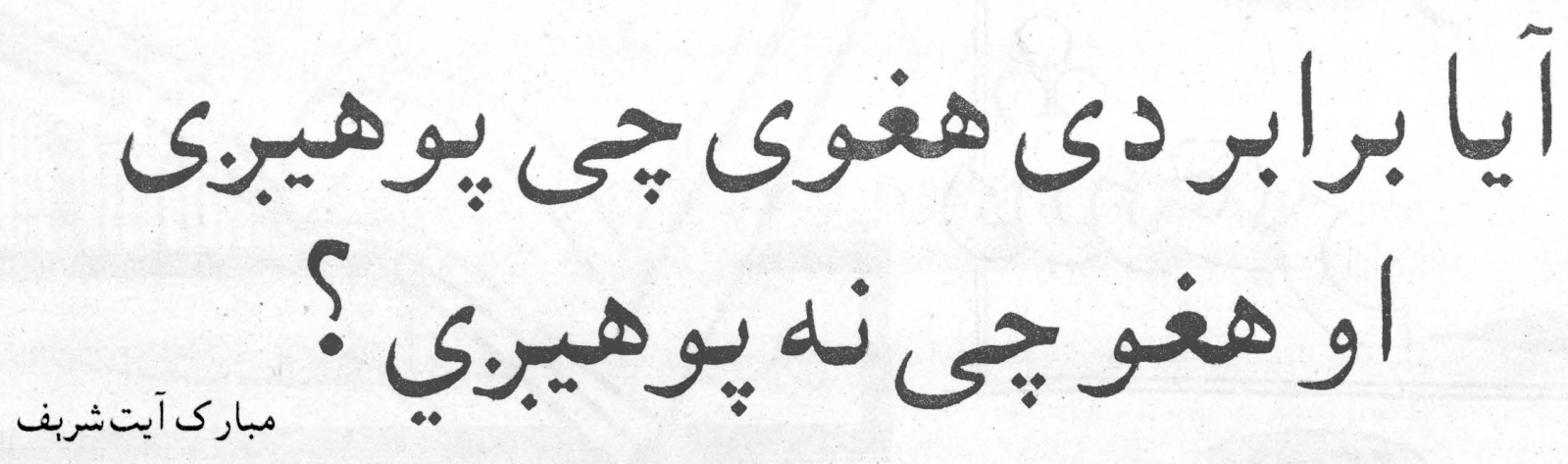

همكارى نهسيموي.

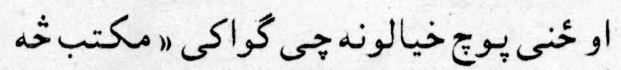

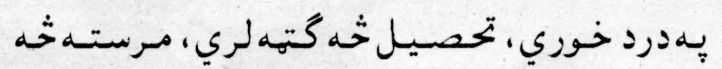

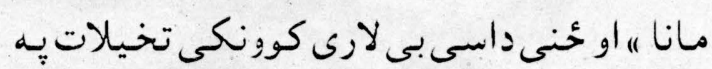

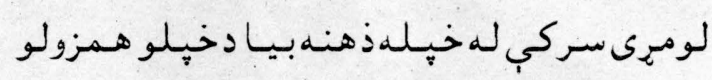

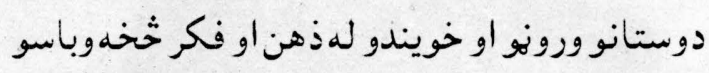

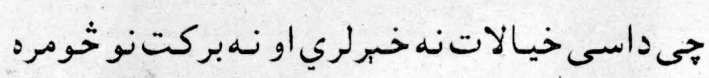

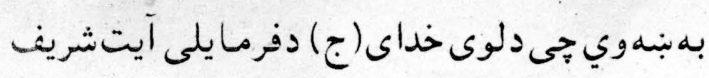

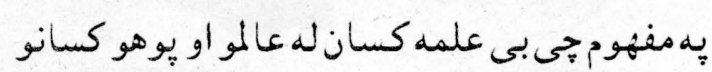

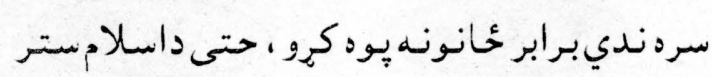

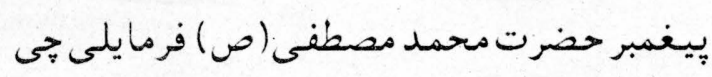

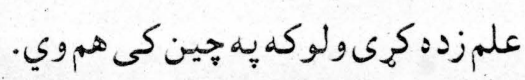

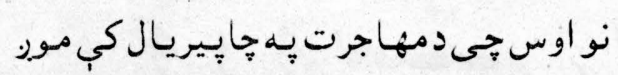

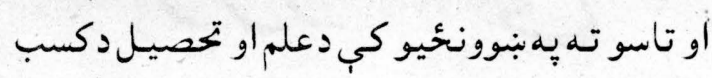

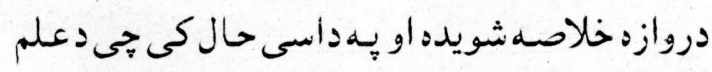

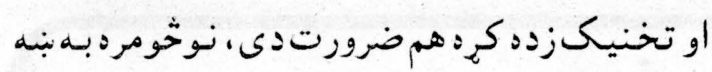

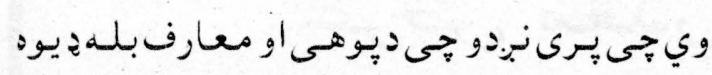

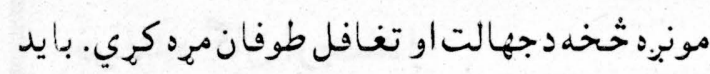

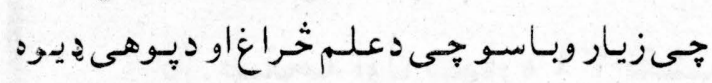
هميشهبلهاو رونبانهوساتو.

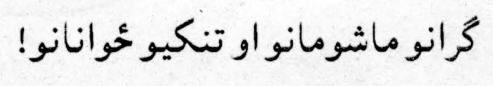

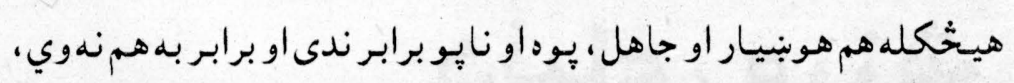

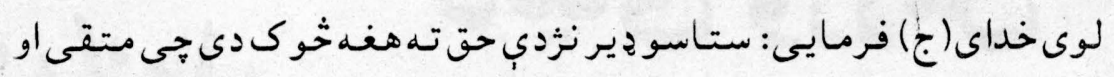

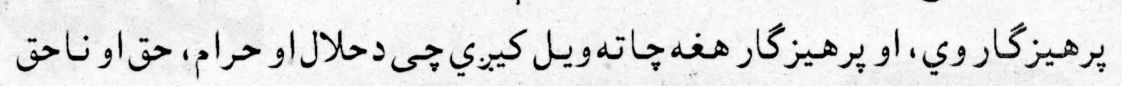

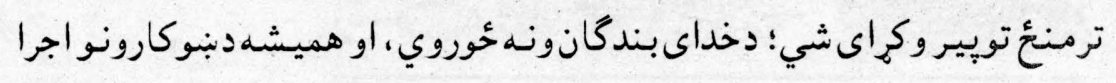

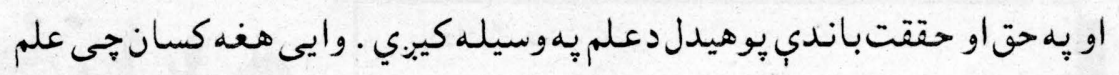

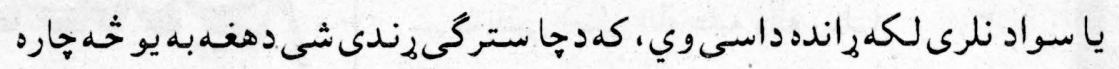

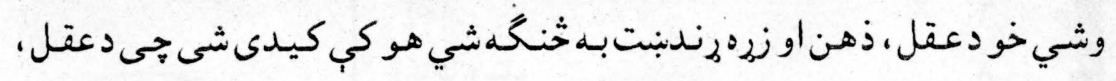

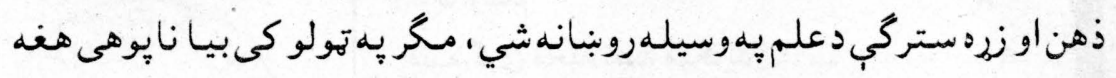

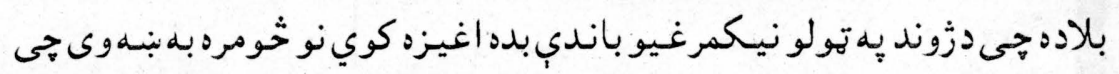

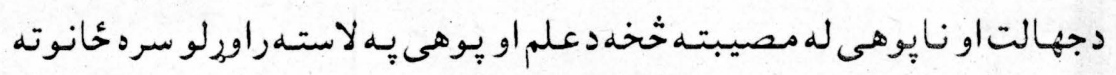

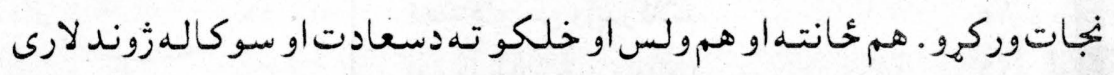

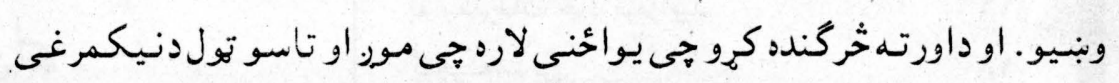

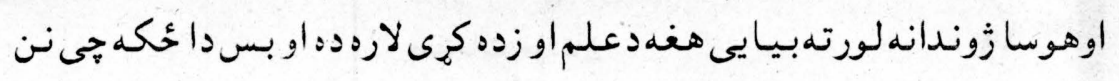

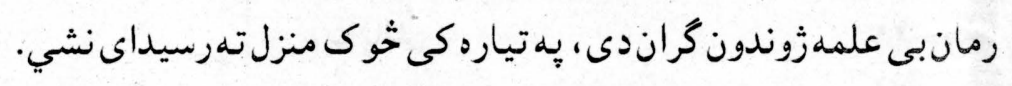

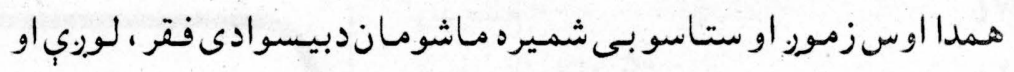

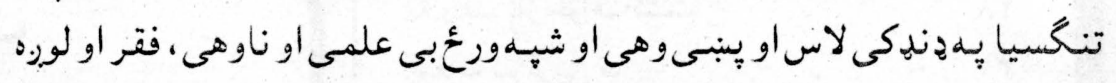

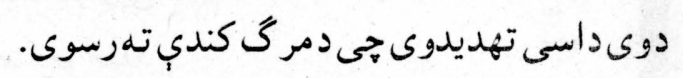

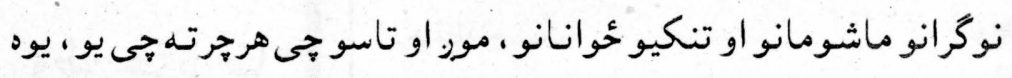

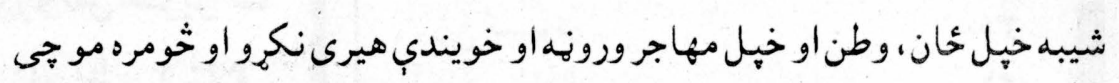

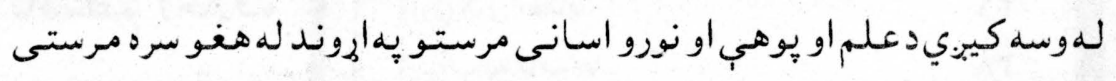

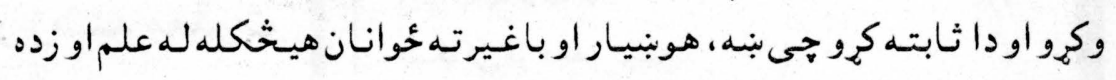

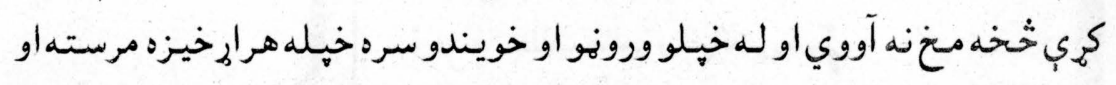


صلى الله عليه وسلم از مكه آكاه شدند،

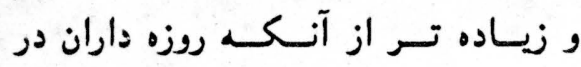
جستجوى هلال عيد هستند، انتظارش را مى كشيدند و همينطور مى بودند تا هئ آنتاب به نيمه مى رسيد و آنكاه به خانه

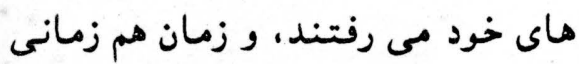

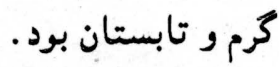
رسول الله صلى الله عليه وسلم زمانى بـه مدينه وارد شدند، كه مردم بـه

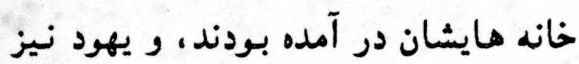
متوجه كار انصار بودند. اولين كسى هم كه رسول الله صلى انى بودند الله عليه وسلم را ديد مردى يهودى بود، إنهي و به صداى بلند فرياد كشيد، و انصار را از تشريف آورى رسول الله صلى الله عليه وسلم آكاه ساخت. توري ردئ مردم بسوى رسول الله صلى الله عليه وسلم شتافتند در حاليكه در سايهء درخت خرمايى قرار داشتند، و همراه شان

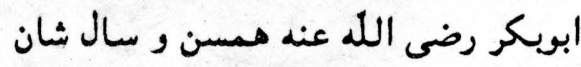
بود.

اكثر مردم رسول الله صلى الله عليه وسلم را ييش از آن نديده بودند.

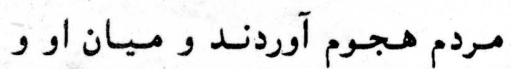

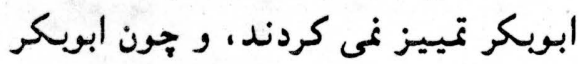

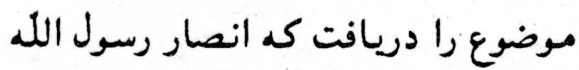
صلى الله عليه وسلم را نمى شناسند رولد برخاست و بارداى خويش برايشان سايه انكند، و مردم متوجه ايشان شدند.

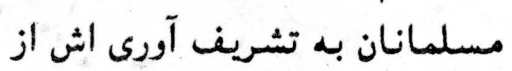

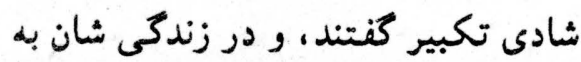
هيج جيزى مانند تشريف آورى رسول الله صلى الله عليه وسلم شاد نشدند. ادامه دارد
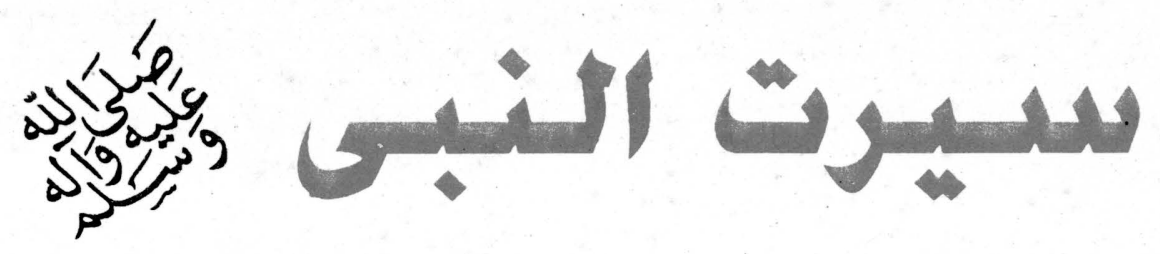

عترجم: عبدالله نامـوش هروى - قسمت: شانسردمم

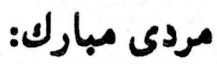

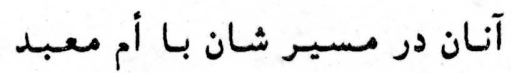
خزاعى رو برو شدند كه كوسفندى داشت دو مان از خستكى جدا مانده از رمه.

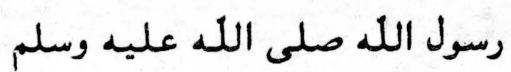
بدست خويش هستـانش را لمس كرد و بسم الله كفت و دعا نمود.

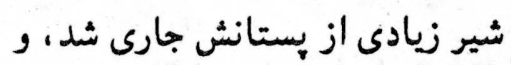

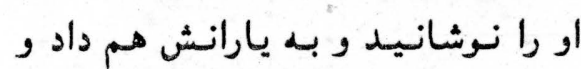
سيس خودشان از آن نوشيدند و دوباره ور آن دوشيد تا ظرف را ير نمود.

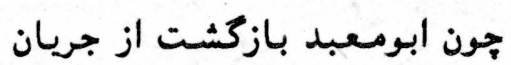

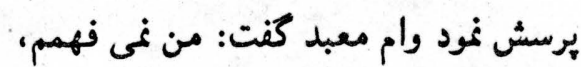

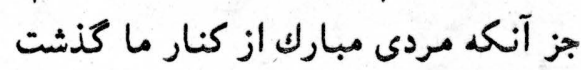
و حكايتش جنين و جنان بود و او را نيكو مردي توصيف نمود . او كنت: والله كمان مى كنم كد او

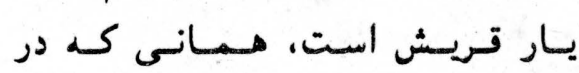
جستجويش هستند. راهنما همينكونه ايشان رأ مى برد هيشد تا آنان را به قبا رسانيد كه در نزديكى هاى مدينه قرار دارد ، و اين روز دو شنبه

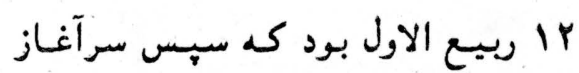
تاريخ اسلامى گرديد.

$$
\text { در مدينه }
$$

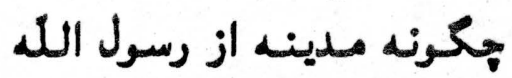

صلى الله عليه وسلم يذيرايى نمود انصار از بيرون آمـدن رسول الله يديله
اينجا بود كه سراقه دانست او رسول

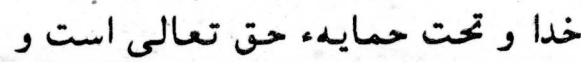
خواهى نـخواهى هيروز است، ازين رو رو

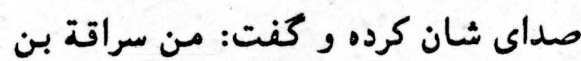
جشعم مى باشم. مرا اجازت دهيد تا با مان

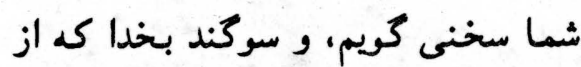
جانب من بشما آسيبى نتخواهد رسيد. رسول الله صلى الله عليه وسلم براى

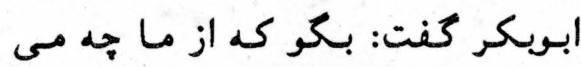
خواهد؟ أبرون سراقه كفتش: أينـه بمن نـامه اي بنويسى، تا نشـانه اي ميان من و تو باشد. عامر بن فهيره براى او جنين نامه اي بر استخوان يا كاغذ نوشت. دستبند هاى كسيرى (يادشياه ايران) در دست سراقد: رسول الله صلى الله عليه وسلم براى سراقه كفت: جطور مى شود كه دستبند هاى كسرى را بيوشى؟ (همينكونه هم شد، زيرا هون تاج، يوند دستبند و كمريند كسرى برأى حضرت عمررضى الله عنه آورده شد، سراقه بن كن سيند مالك رضى الله عنه را خواست و آن را به آله

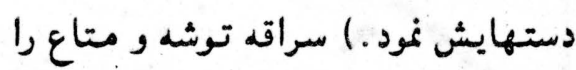
برايشان عرضه داشت ولى رسول الله

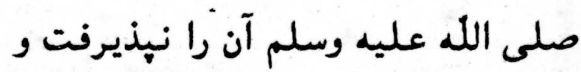
كفت: ما ر ا از نظر مردم ينهان دار. 


\section{0}

(2) IrVV سال سوم شماره سى وهفتم سنبلd
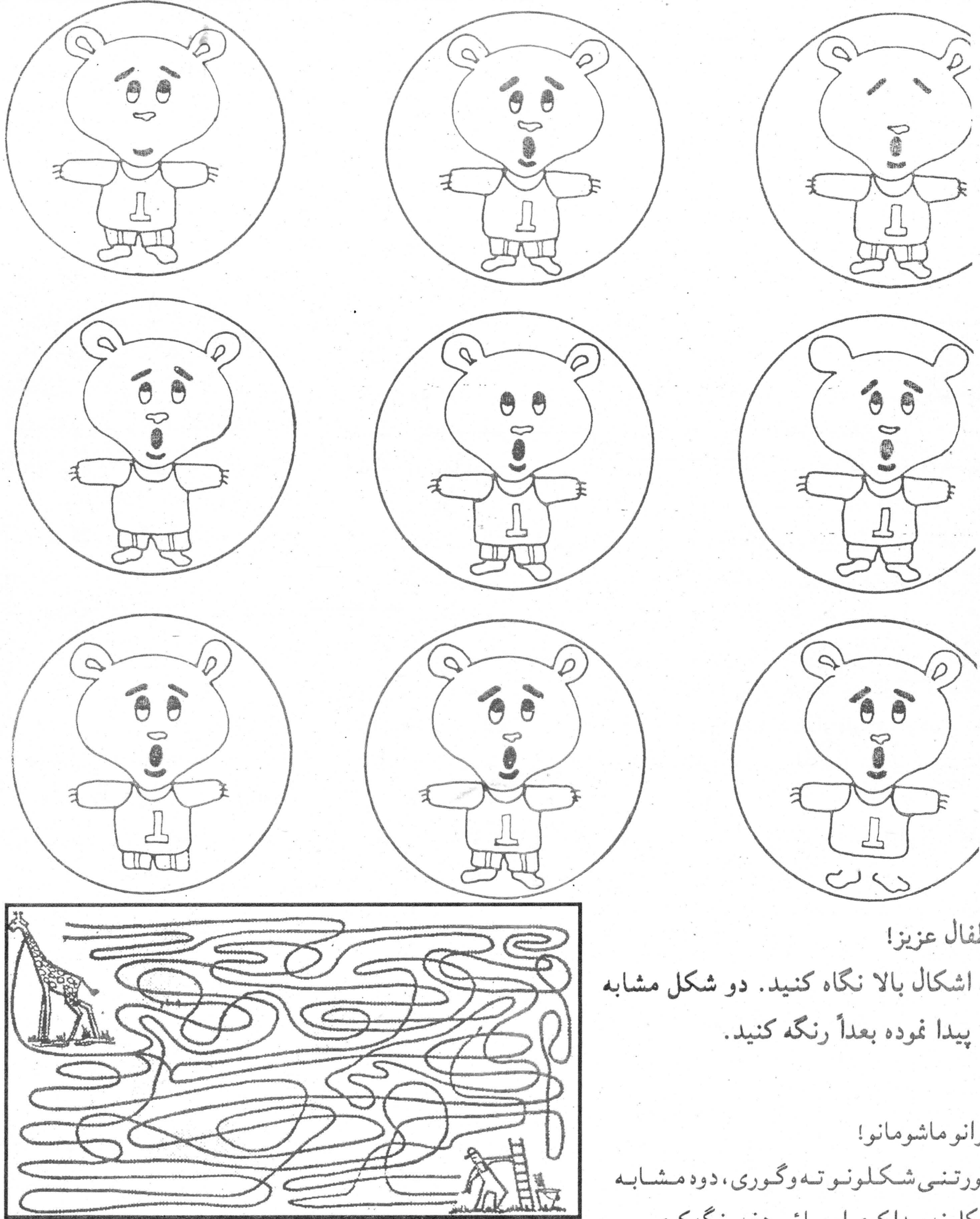

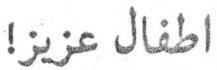

به اشكال بالا نعاه كنيد. دو شكل مشابه را بيدا تموده بعداً رنكه كنيد.

اين شكل را ديده بكوئيد كدام ريسمان به خُردن زرافه بسته شده است.

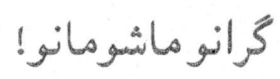

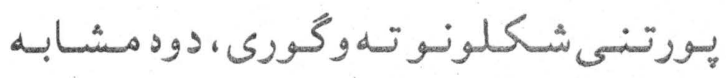

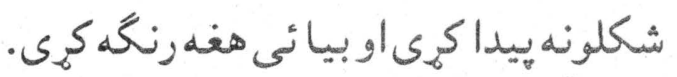
اخر توجه كنيد حتماً آنرا بيدا مي كنيد. 
همان جوان جيويان و ناتوان مرد بزرقى

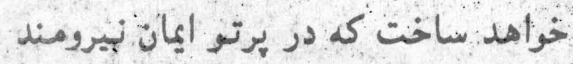

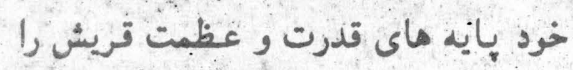

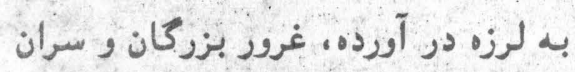

$$
\text { قريش را درهم خواهد شكستا }
$$

آرى همان جوان ناتوان كه جرأت

نيكرد به مجلسى كه يكى أز اشران هكه در آن بشركت داشت، آزادانه وارد شود، و از رعب زجر و شكنجه. آنان،

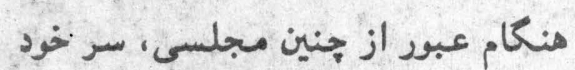

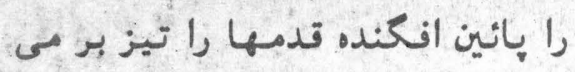

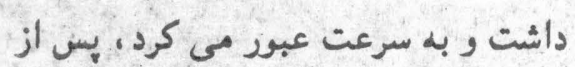

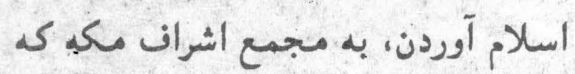

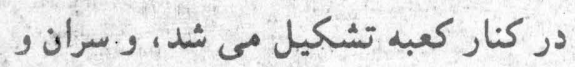
بزركان قريش در آنبا كرد مى مئ آمدند

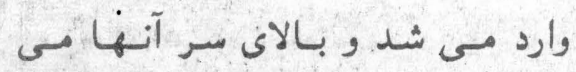

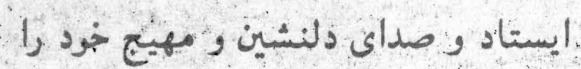

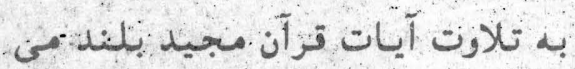
كرد:

آنعاه به تلاوت آيات قرآن ادامه

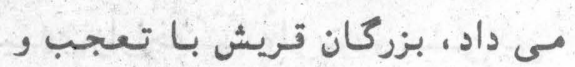
حيرت به اين صحنه مى نكريستند و ونى فرئ

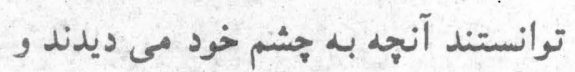
با كوش خود منى شنيدند باور كندا! آرنى

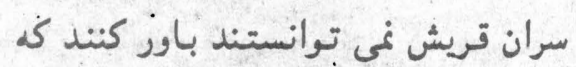

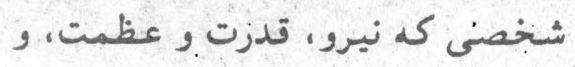

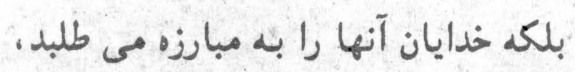

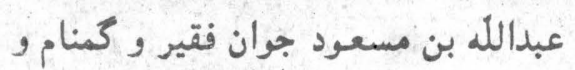

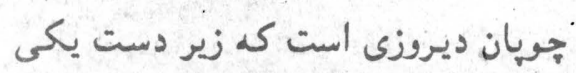
از اشراف آنها بسر منى برون

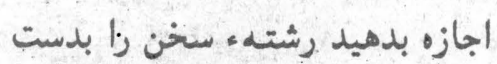

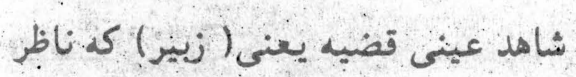

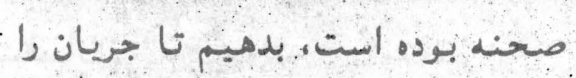
بيان كند، زبير هى قريد: (ادامهدرود)
كونسفند كرده فرمود : جمع شو، فوراً جمع شد و به حال اول باز كرديت

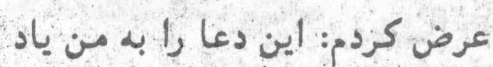
بذه، فرموذ: "اتو جوان تعليم يافته ائ خواهى شده.

عبدالله بن مسعود وقتى كه ديد

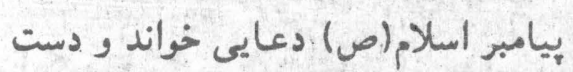

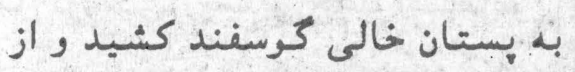

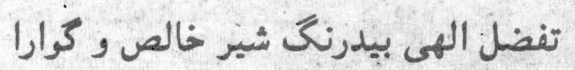
در آن جمع شد، غرت حيرت كرديد. آنروز عبدالله بن سسعود هنوز عنى عرديد

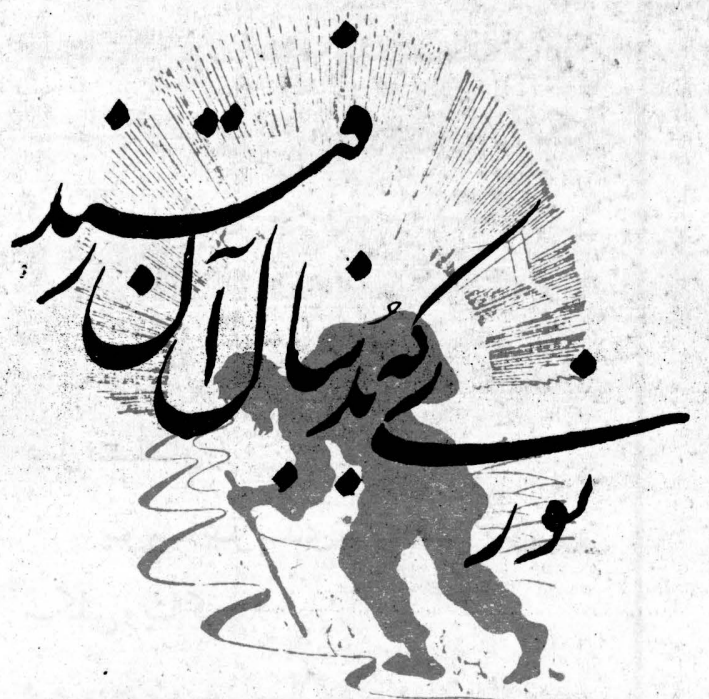

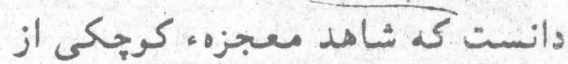
ييابمبر اسلام(ص) است وطولى نبخواهد

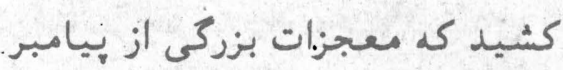

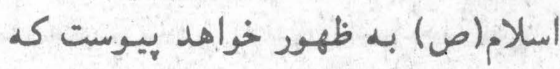

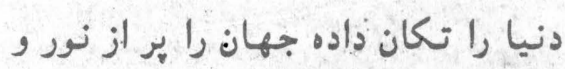
هدايت خواهد ساخت.

عبدالله بن مسعبود هنوز نمى منى

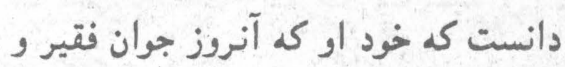
ناتوان و خويانى بيش نبود كه كوسنفندان

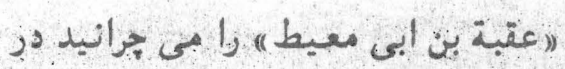
آينده يكى از معجزات بزرى اسلام خواهد بود و نيروى ائان و اسلام از بندان

\section{عبالله بن مسعوور(ر)}

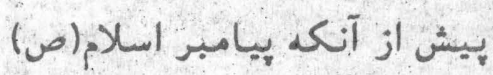
خانه „ارتم بن ابى ارقمه را بعنوان مركز

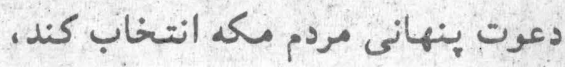
عبدالله بن مسعود به آنحضرت ايمان آروده بود. عبدالله بن مسنعود ششمين

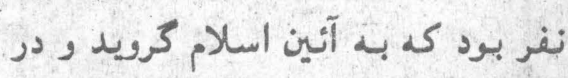

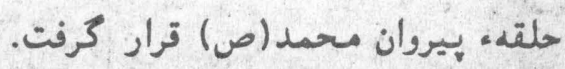

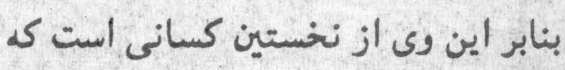

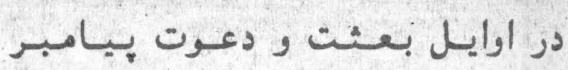
اسلام:(ص) ، ائان آورده اند. عبدالله بن مسعبود، نخستين ملاقات خود را با بيامبر اسلام) بندام) جنين توصيف مى كند: "اجوانى نسوس بودم، كوسفندان

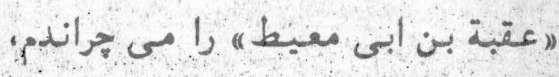

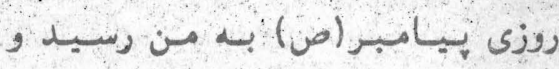

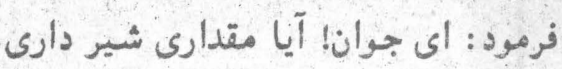
به من بدهى بخورم." هرئ كنتم: كوسفندها نزد بن من امانت

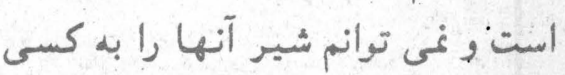
- pola ييامبر (ص) فرمود: آيا كوسفند

بلدون شير دارى كه جوجهه دار نباشد؟

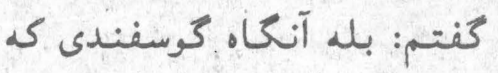
شيرده نبود آوردم، ييامبر (ص) كوسفند

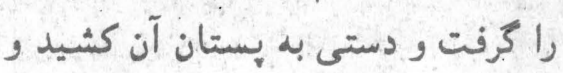
دعايى خواند، فوراً بستانهاى كوسفند

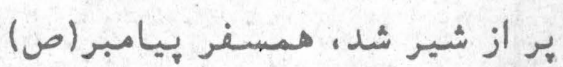

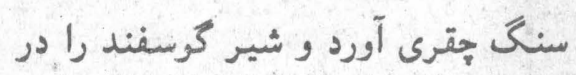

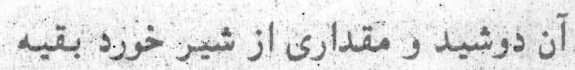
را به من داد من نيز خوردمب. آنعا، ييامبر (ص) رو به يستان 


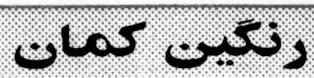

سال سوم شماره سى وهفتم سنبله ITVV

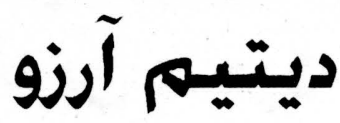

مر هور |"بينوا| (1)

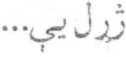

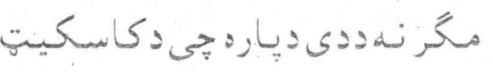

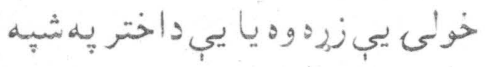

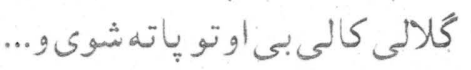

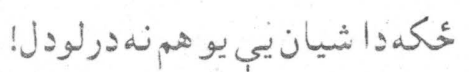

او ولى يميثرل

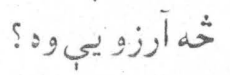

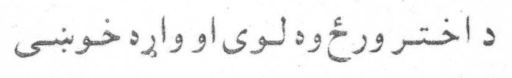

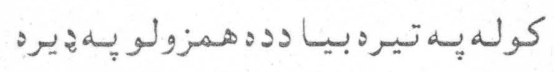

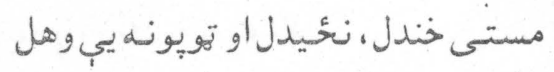

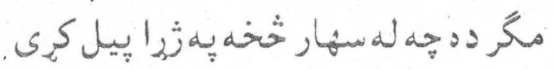

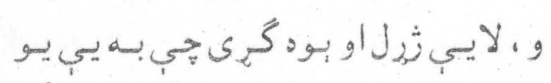

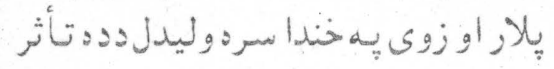

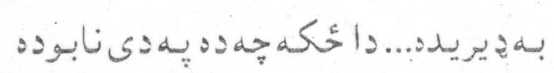

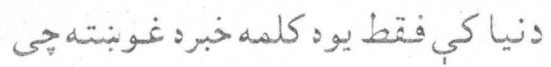

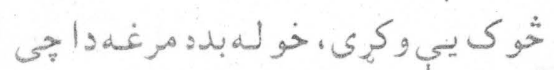

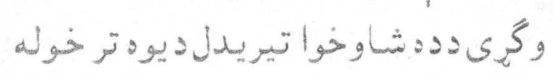

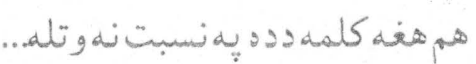

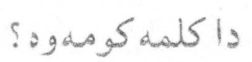

Salo

ثاثن

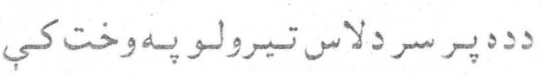

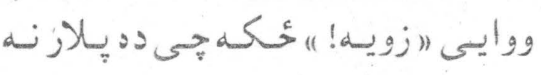

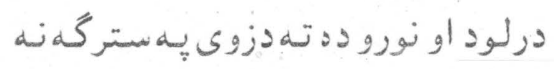

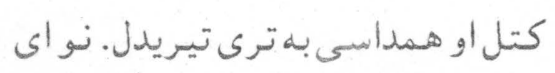

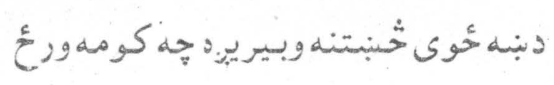

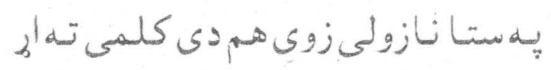

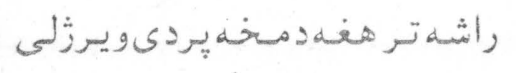

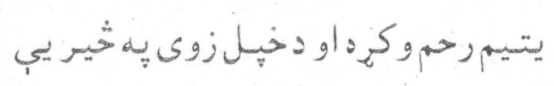

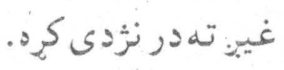

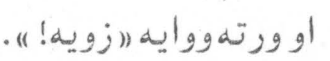

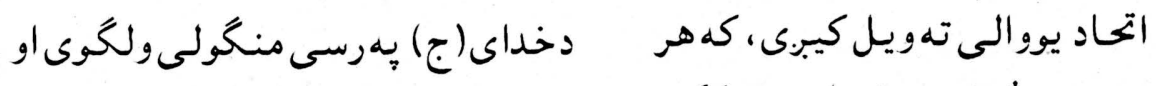

$$
\text { متفرق كيبرى مهه ه. . }
$$

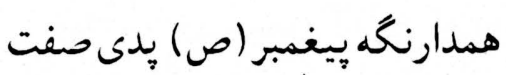

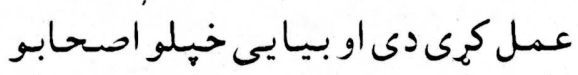

كراموتهوصيت او نصيحت كرى ندى جيى

عمل ورباندى وكيى او بيا هم حضرت

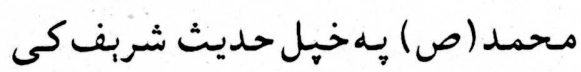

مسلمانانوتهوعظ او نصيحت كوى:

مسلـمان مؤمن دبـل مؤمن لِـاره لكه

ديسوال دى جي يسو بـل سـرهكـلـكـوى.

$$
\text { (تينهوى). }
$$

او بيا يـى هم فرمايلى لىى: مسلمان

$$
\text { دبل مسلمانورور دى. }
$$

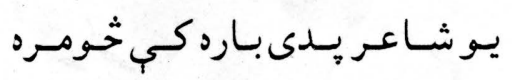
بنبكلى وينا كريده:

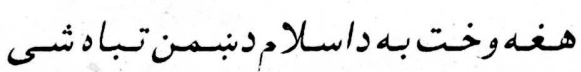

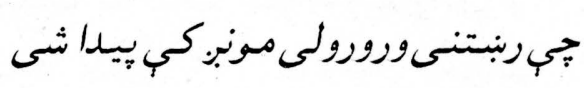

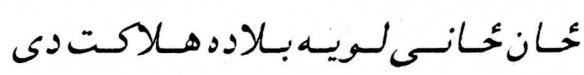

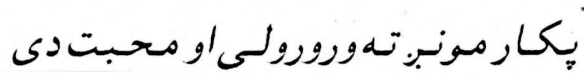
يه وحدت كسى بـه دنبـمن زير او زبرشى

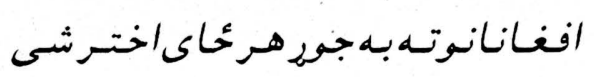

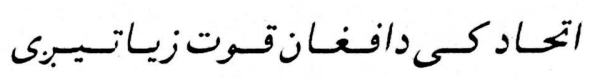
يـهنفاق كسى ولسسونسه محسوه كيبرى. دمحمداكرم همت بِه قلم ددارحراء

للانجال داوو تولنحى زده كوونكى

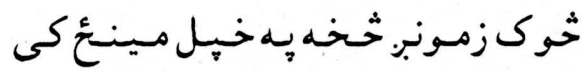
مينه، مـحبت او دوستـى او اتفاق ، اتحاد

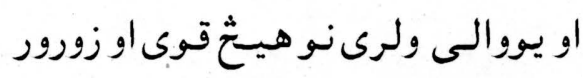
لاس بهورباندى دياسه نشى او كه جيرى

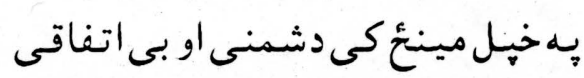

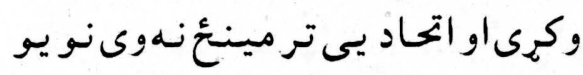
كمزورى او ضعيف سرى به همرورباندى غالبشى.

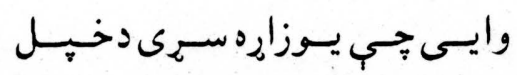
حنـكدن يهوخت كى خو غشى راتهول او ويى ترل ، خيلو زامنو ته يبى وويل : او دهغو دماتولو امر وكي ، زامنو ئسى هر يود

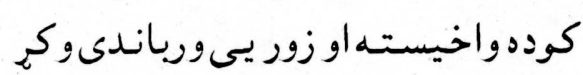

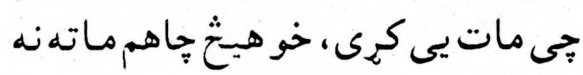

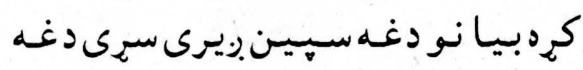

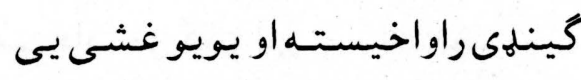

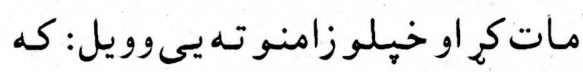
جيرته تاسى به خيل مينيخ كي با اتفاق او

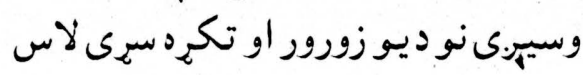

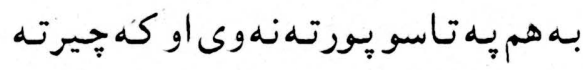
تـاسو بسى اتـفاقى كوى او بسى اتـفاقـه

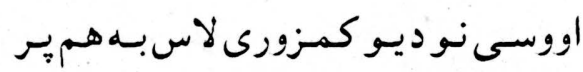
تاسى برشى.

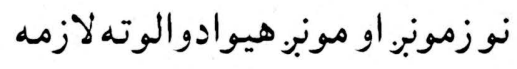

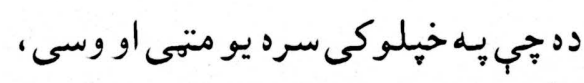

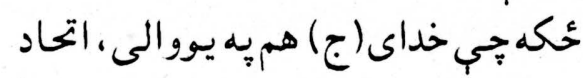

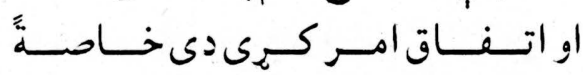

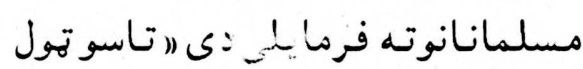




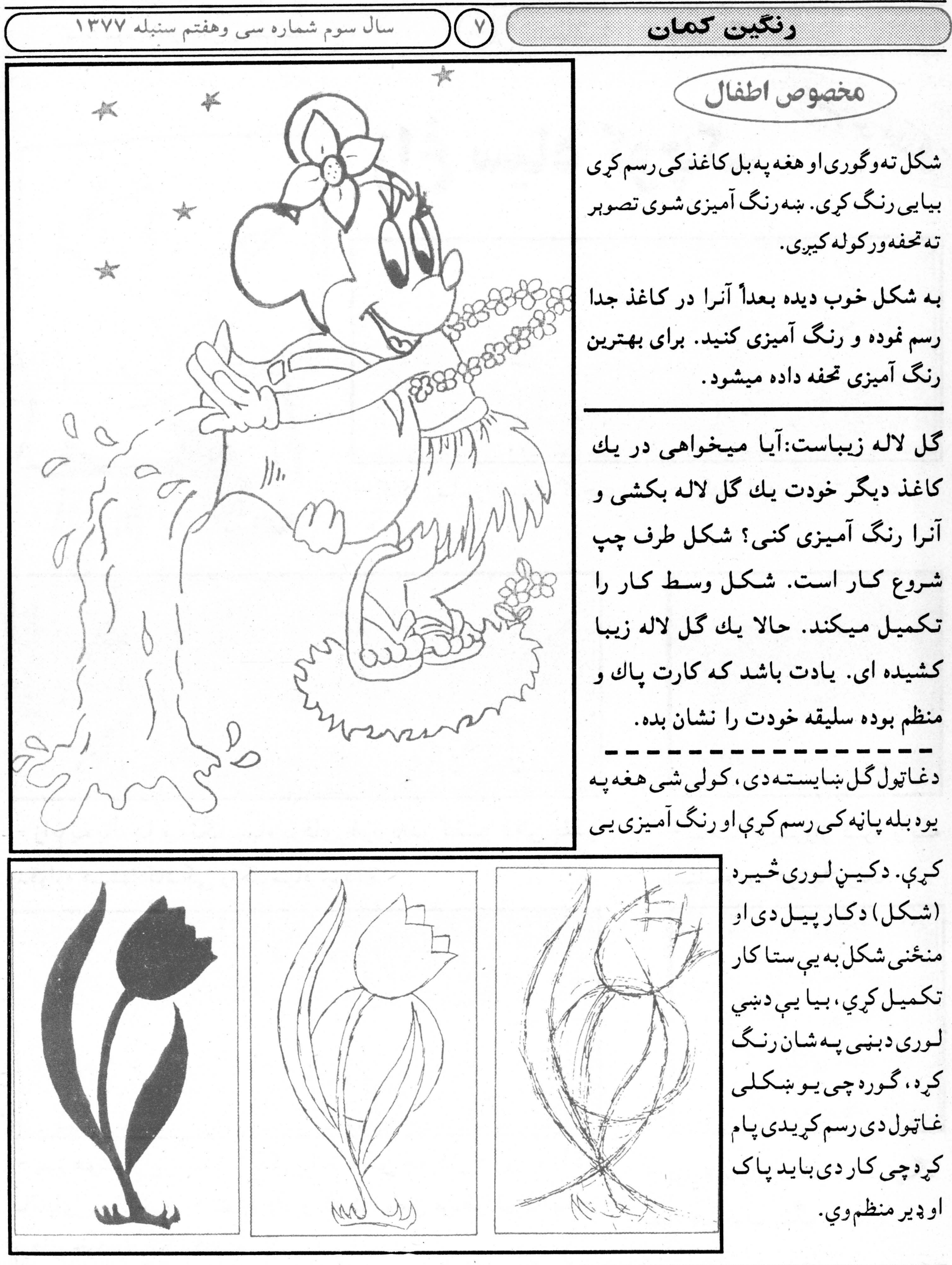




\section{قريـه كوهـسـار}

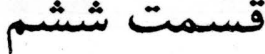

خلاصهء آنجه كذشت:

دوستان كرامى!

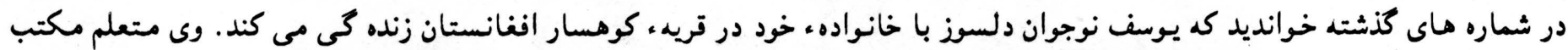

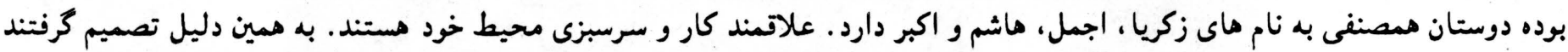
تا ميدان مكتب را ترميم نموده و تغيرات در آن بيآورند. كار در ميدان مكتب ران را به همكارى همديكر واداره شروع نمودند بابه زمرد و سر معلم
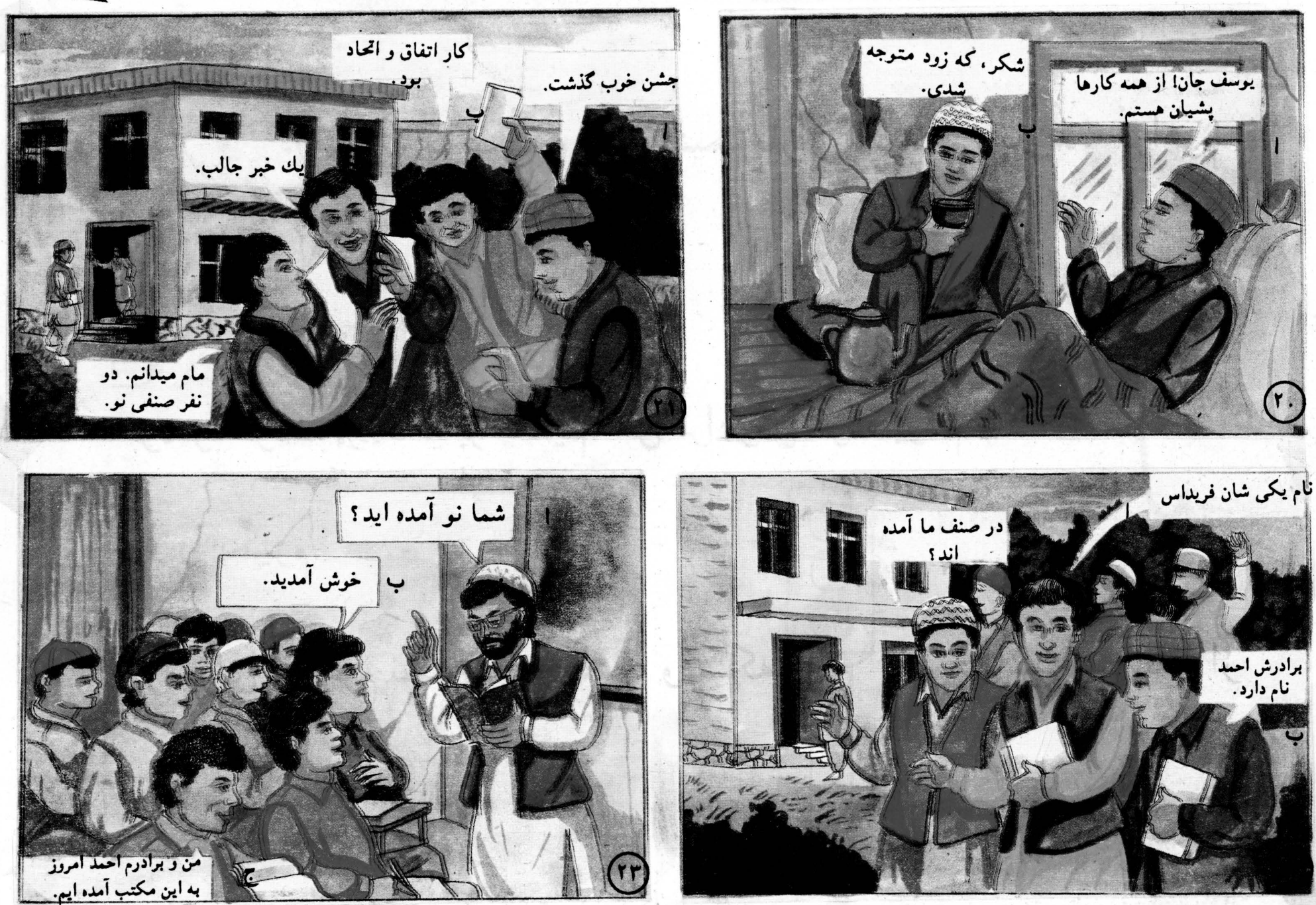

آن شب در خانه ما قصه، شاكردان نو و تعريف از ماز

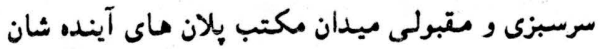

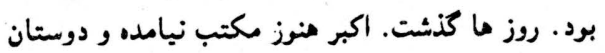

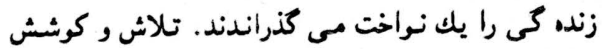

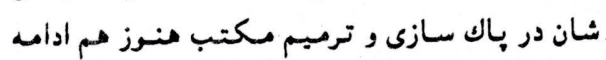

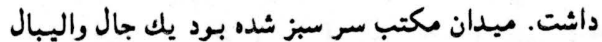

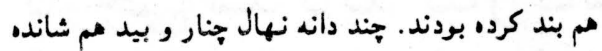

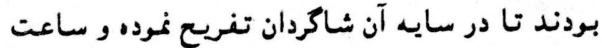

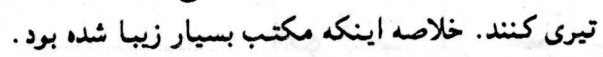

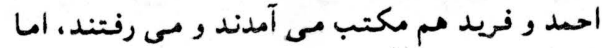

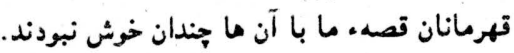

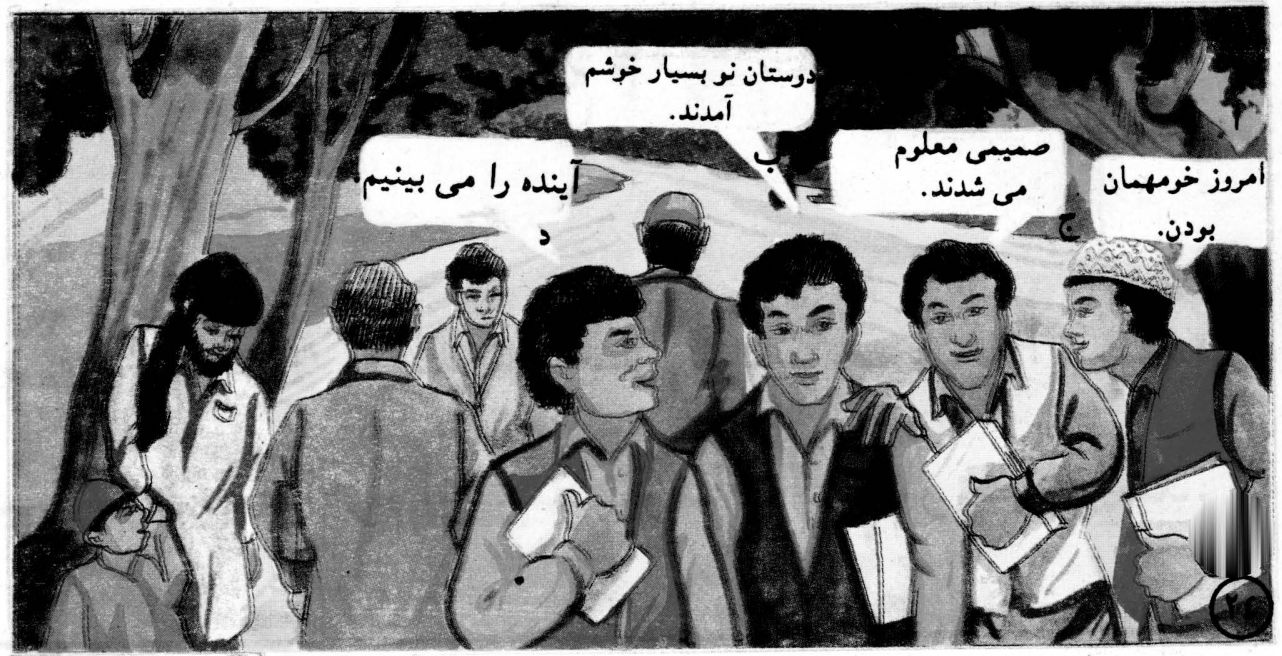


سال سوم شماره سى وهفتم سنبله IrVV

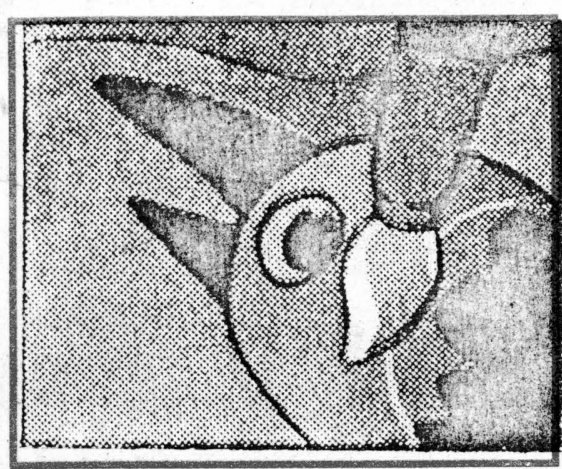

- كاكا رسام زاغ سياه را زرو

$$
\text { رن كرو }
$$

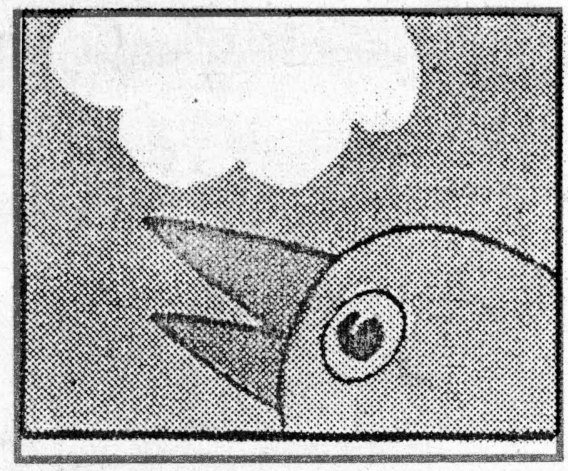

- وقتي نزد آنها رسيد، زاغها

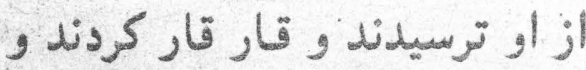

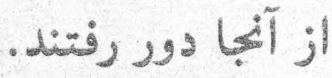

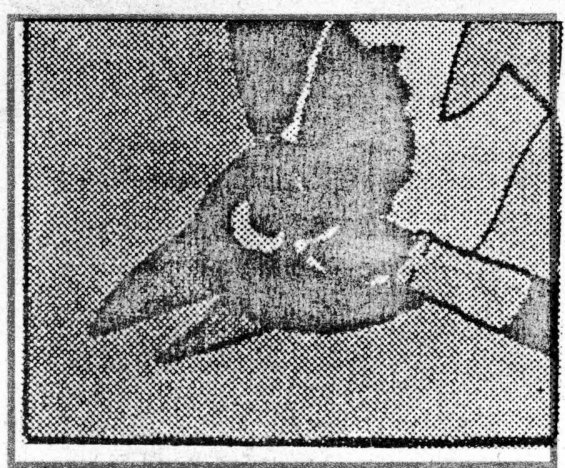

: (اويلدي كه بوم هوشيار درست

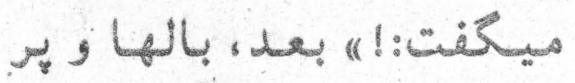

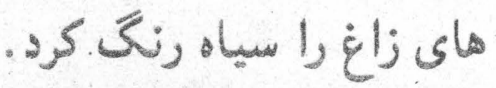

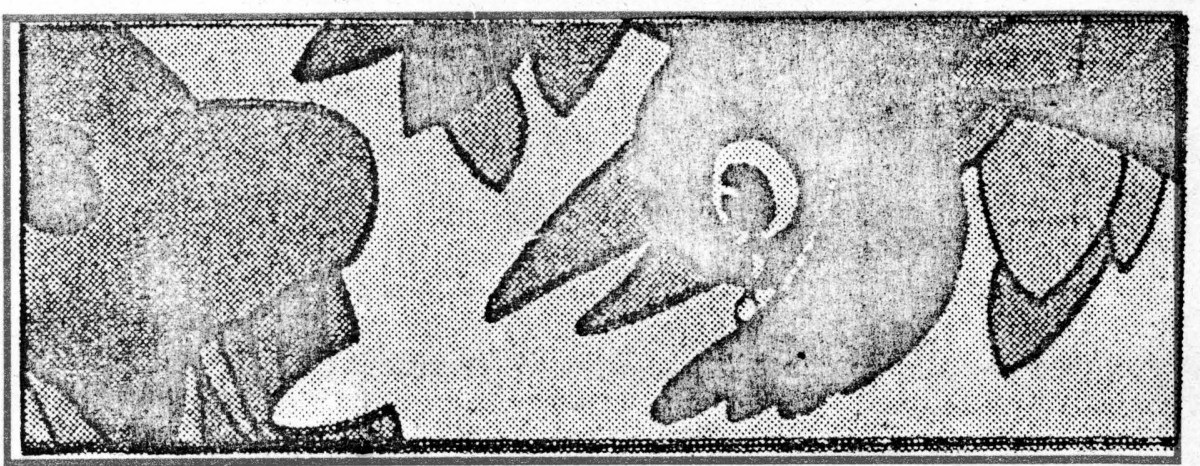

- زاغ سياه، ناراحت شُند و به كاكا رسام كفت: (ا خواهش ميكنم

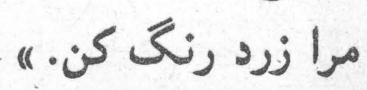

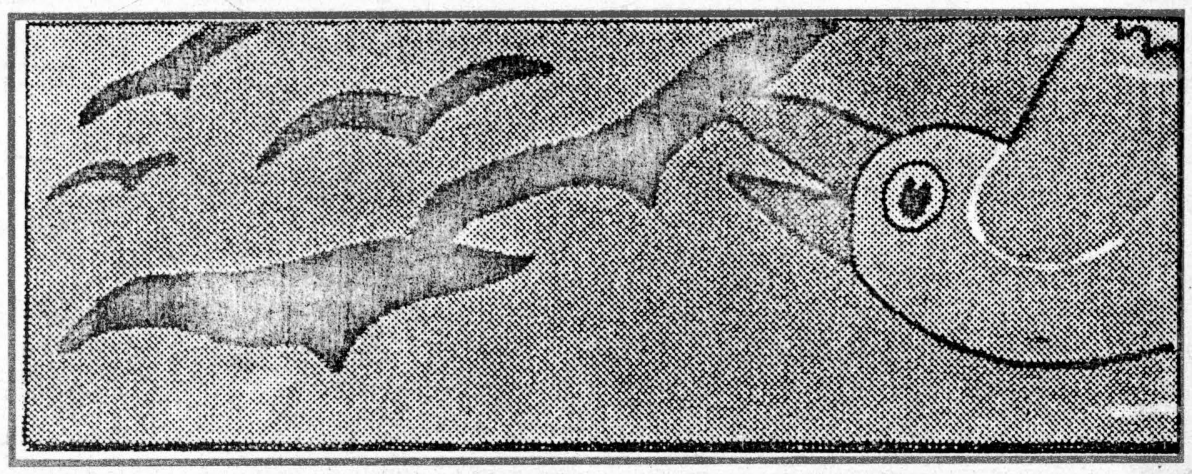

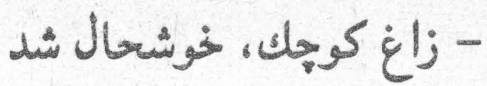

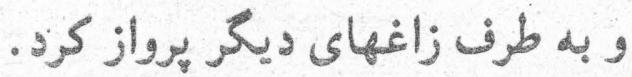

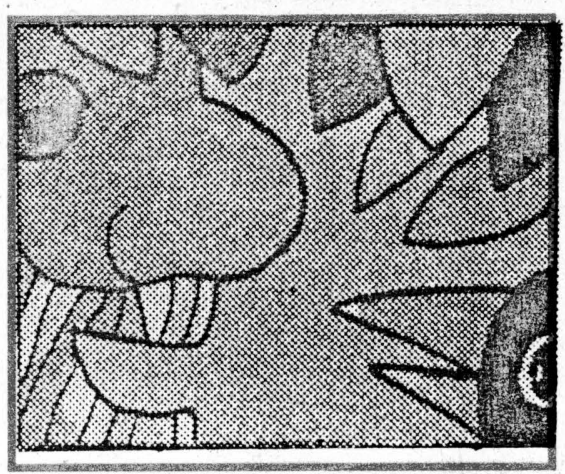

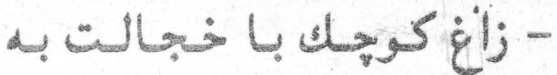

هـ

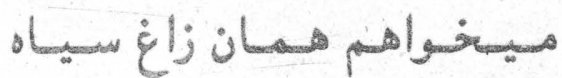

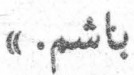

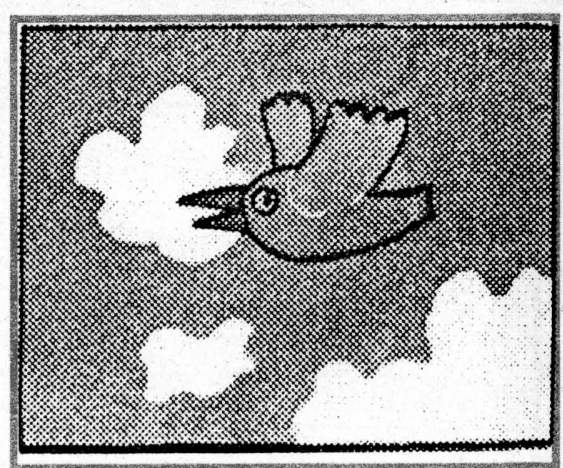

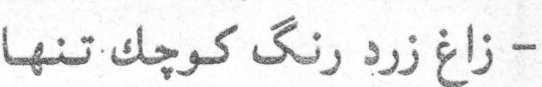

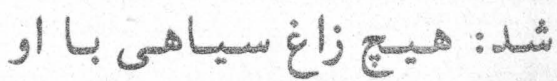
ووسيت نسمى شهل.

\section{اشتباهات كوجِك مشكلات بزرگ را به بار مى آورد.}


IrVV سال سوم شماره سى وهفتم سنبله

\section{s) ls illol}

درسابق در قبائل عرب رواج بود كه مردم مال

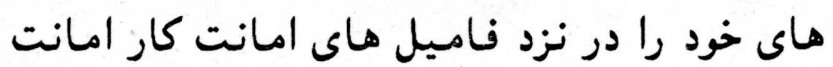

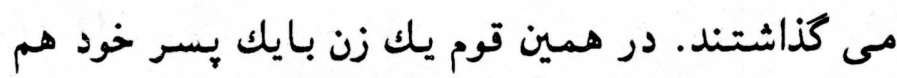

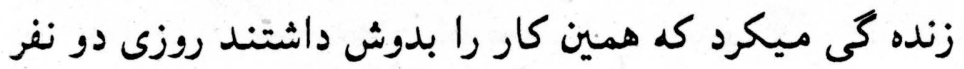

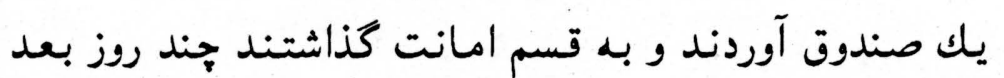

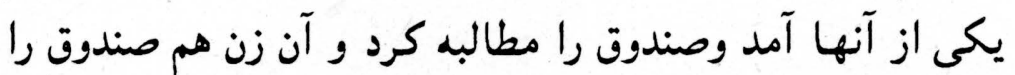

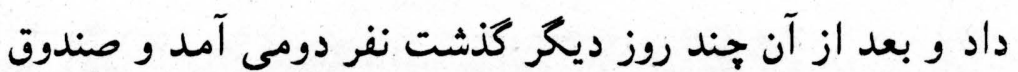

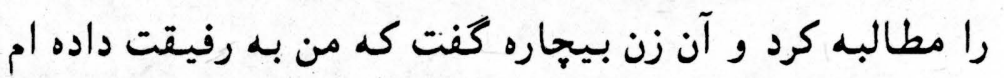

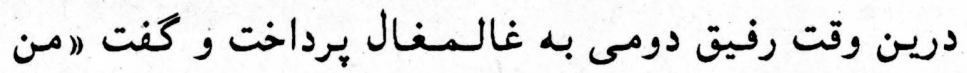

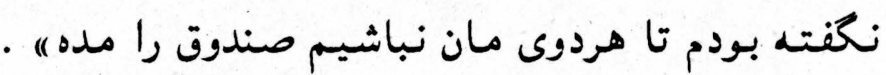

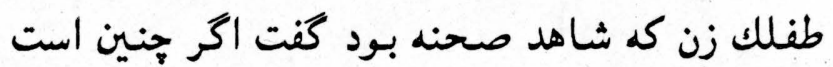

برو رفيقت را بياور تا صندوق را تسليمت بدهيم باشنيدن اين حرف مرد خجل

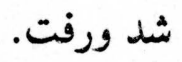

\section{a}

بود نبود يك جنحل بود. در يك

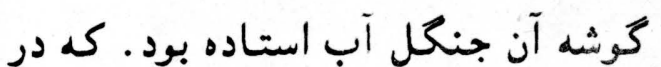

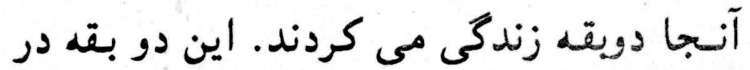

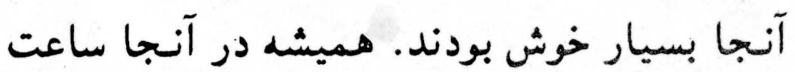

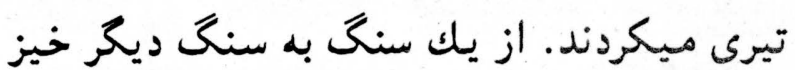

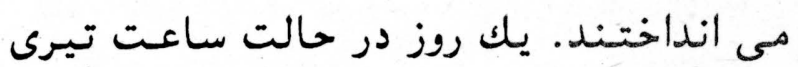
بودند. كه يك مرد خراب آمد و آنها را آزار داد داد

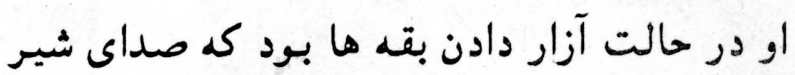
را شنيد. او بسيار ترسيد بقه ها را انداخت ورفت بقن ها به تعجب سيل كردند و از رفتن او بسيار

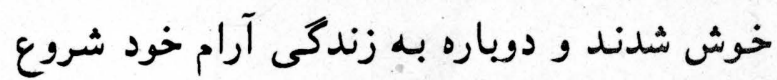
نمسودند.

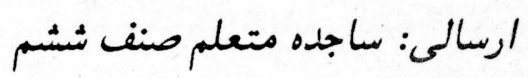
مكتب مستوره افغان

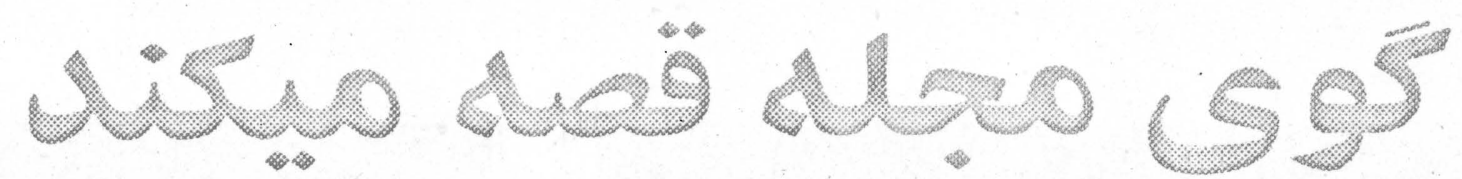

\section{موش و قروت}

نَّان

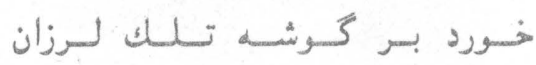

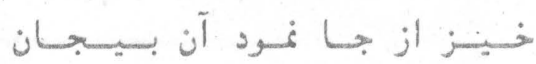
بـر كرفست هلنق هسوشك نسادان

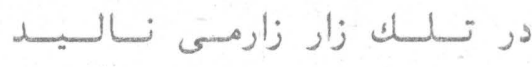

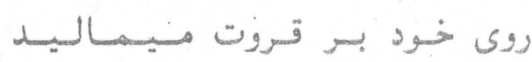
هوش در ساعتي كه بان ميداد كفتت بر نـفس فتينه لعنت باد

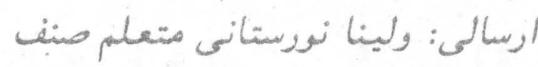

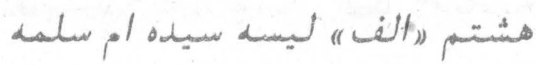

تـا شبسوة سيسى غـار خريسش روان

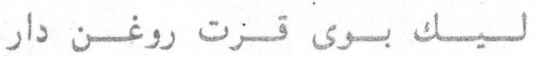

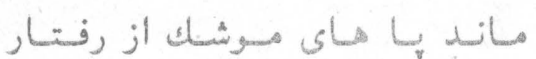

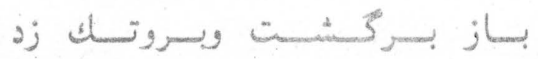

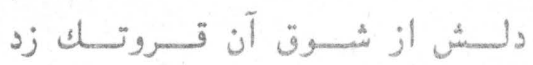

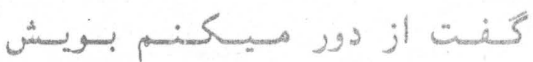

هسى زنم بسوسـهنه بـر سـر و رويسش

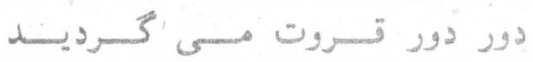

دلش از شـوق و تسرس مسي لـرزيـد
مبوشكى ره بـجسوال كُندم داشت

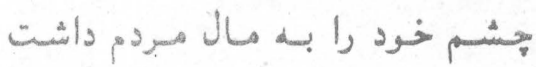

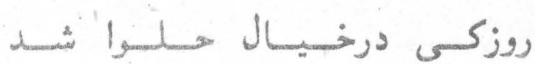

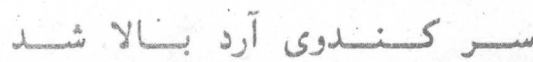

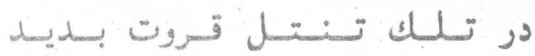
رنشش إز ترن جان سفيد بريد

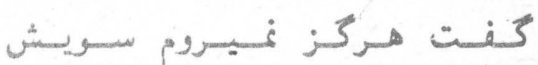
لاكسن از دور هـيـكنـم بستيسش

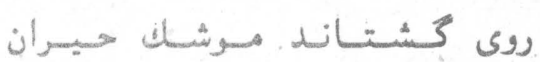


سال سوم شماره سى وهفتم سنبلd نlos
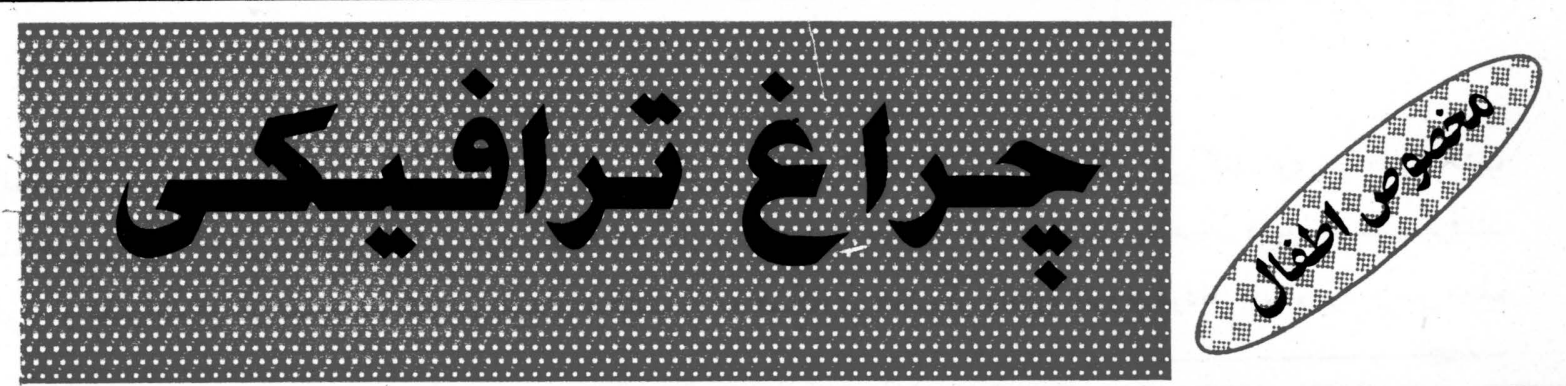

$\overbrace{11}$

به مكتب مى رفتيم. باران شديد مى باريد. خواهرم
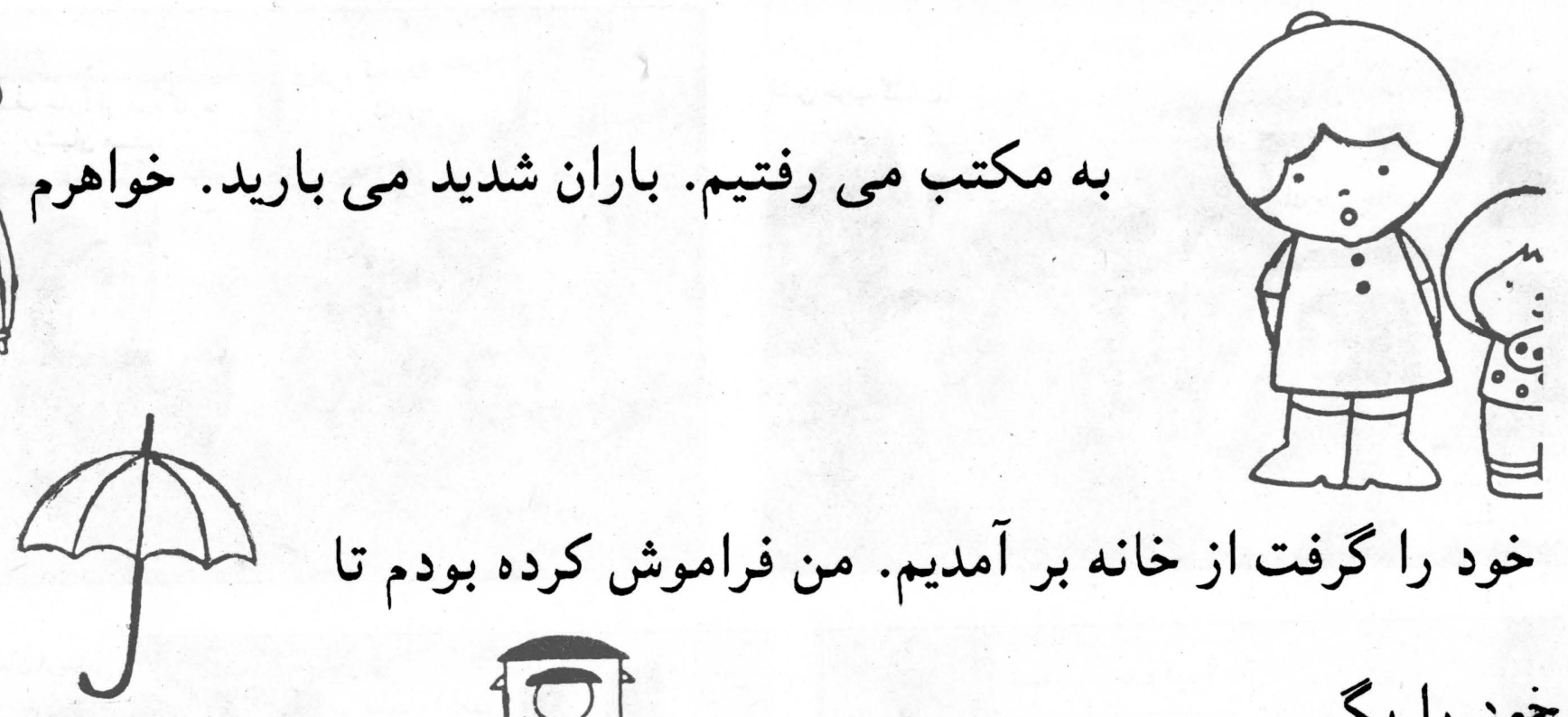

خود را كرفت از خانه بر آمديم. من فراموش كرده بودم تا

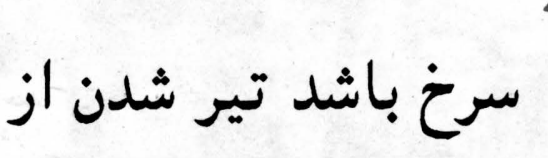

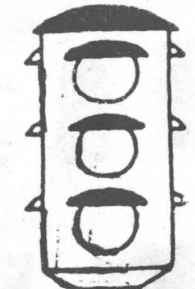

را براى خواهرم نشان داده كُنتم: وقتيـه

سرك خطر دارد، ما بايد ايستاده شيم تا موترها تير شوند و وقتيكه

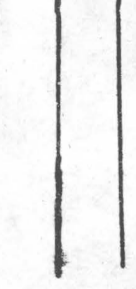

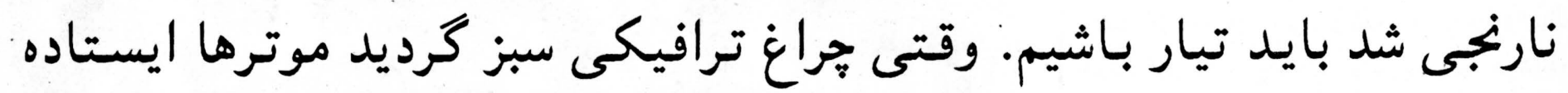

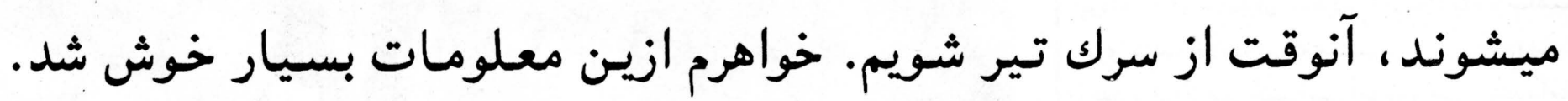




\section{قريـه كوهـسـار}

خلاصهء آنجه كذشت:

دوستان كرامى!

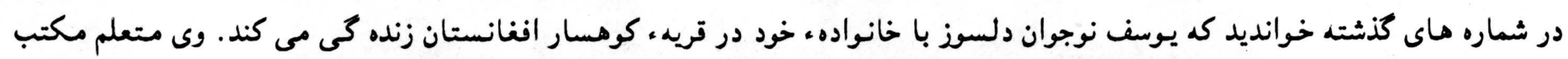

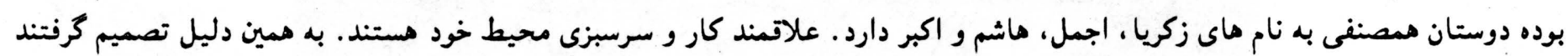

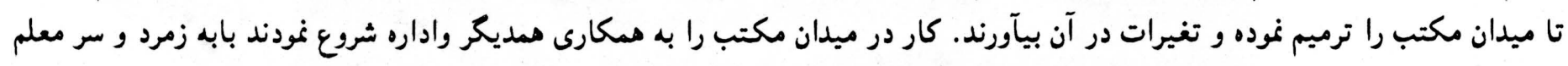
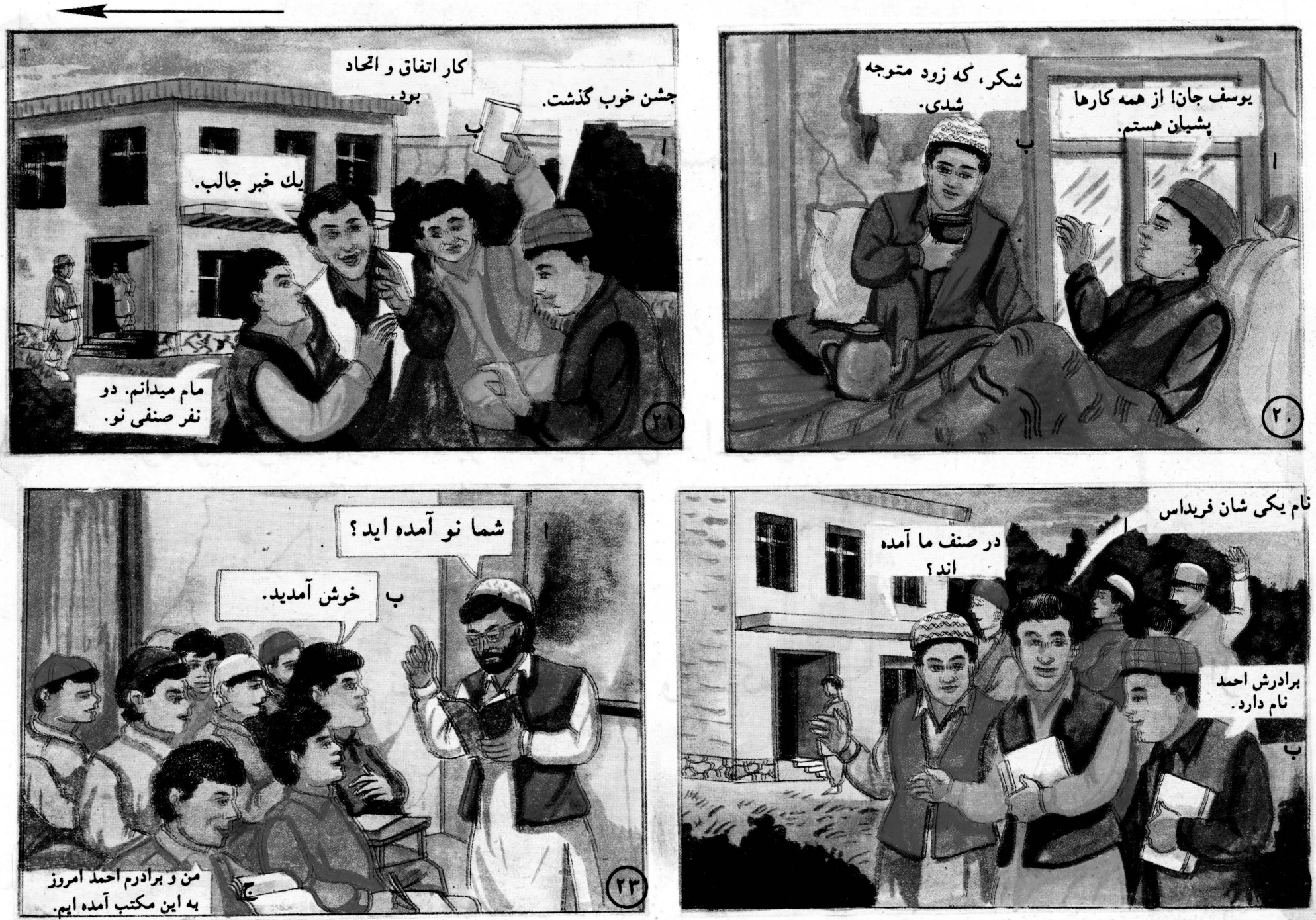

آن شب در خانه ها تصه، شاكردان نو و تعريف از سرسبزى و مقبولى ميدان مكتب بلان مان ماي آينده شان

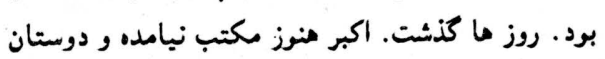

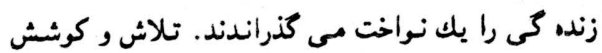

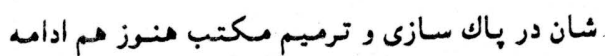

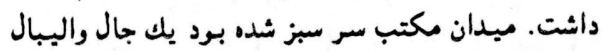

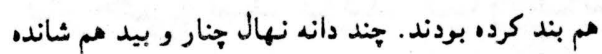

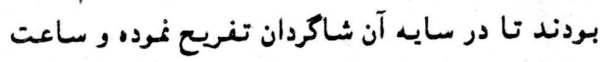

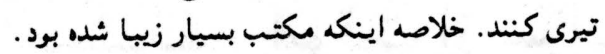

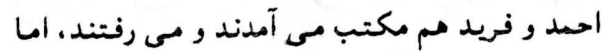
قهرمانان تصه، ما با آن ها جندان خرش نبون فيودند.

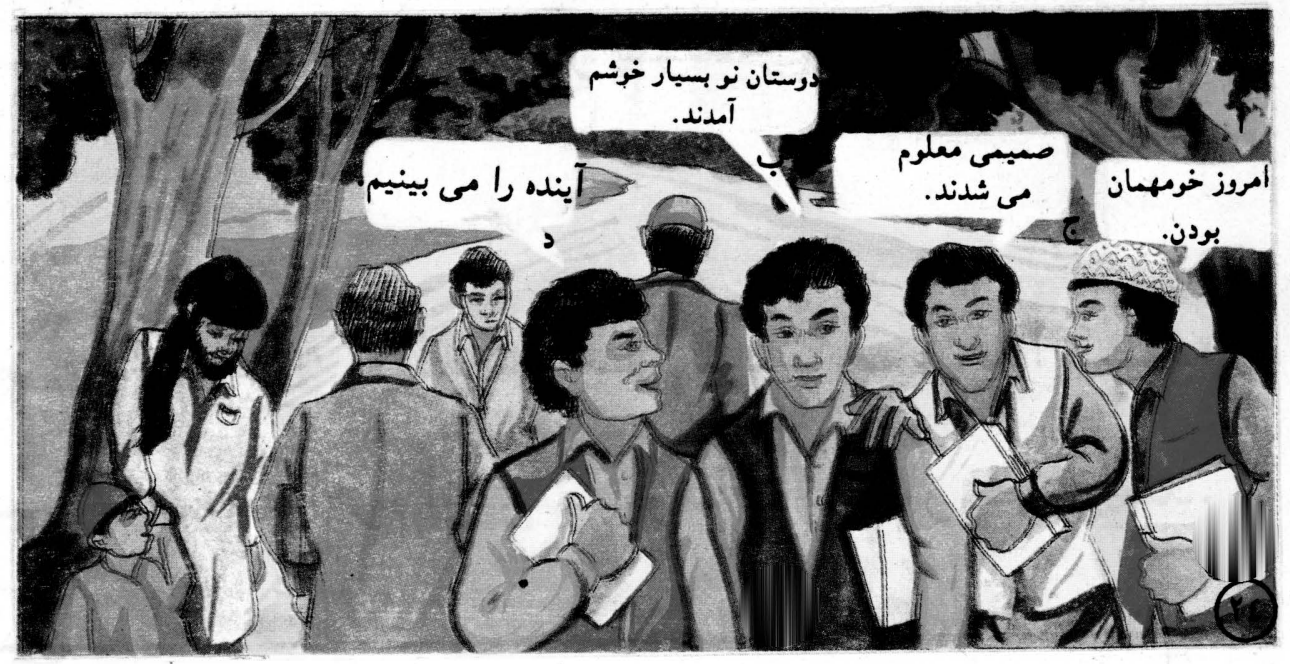




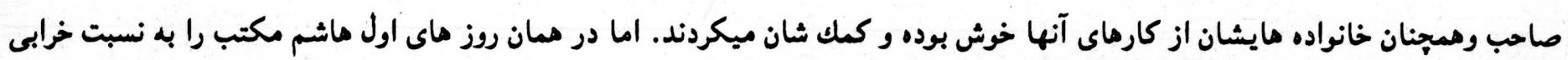

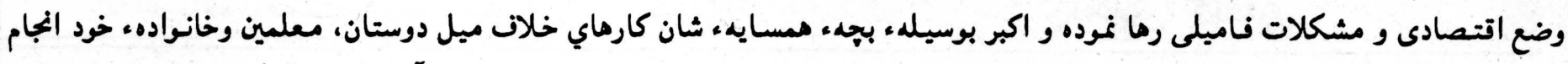

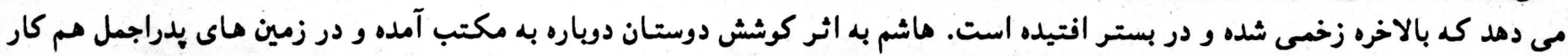

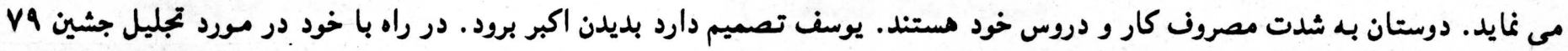

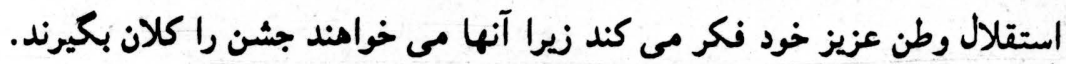
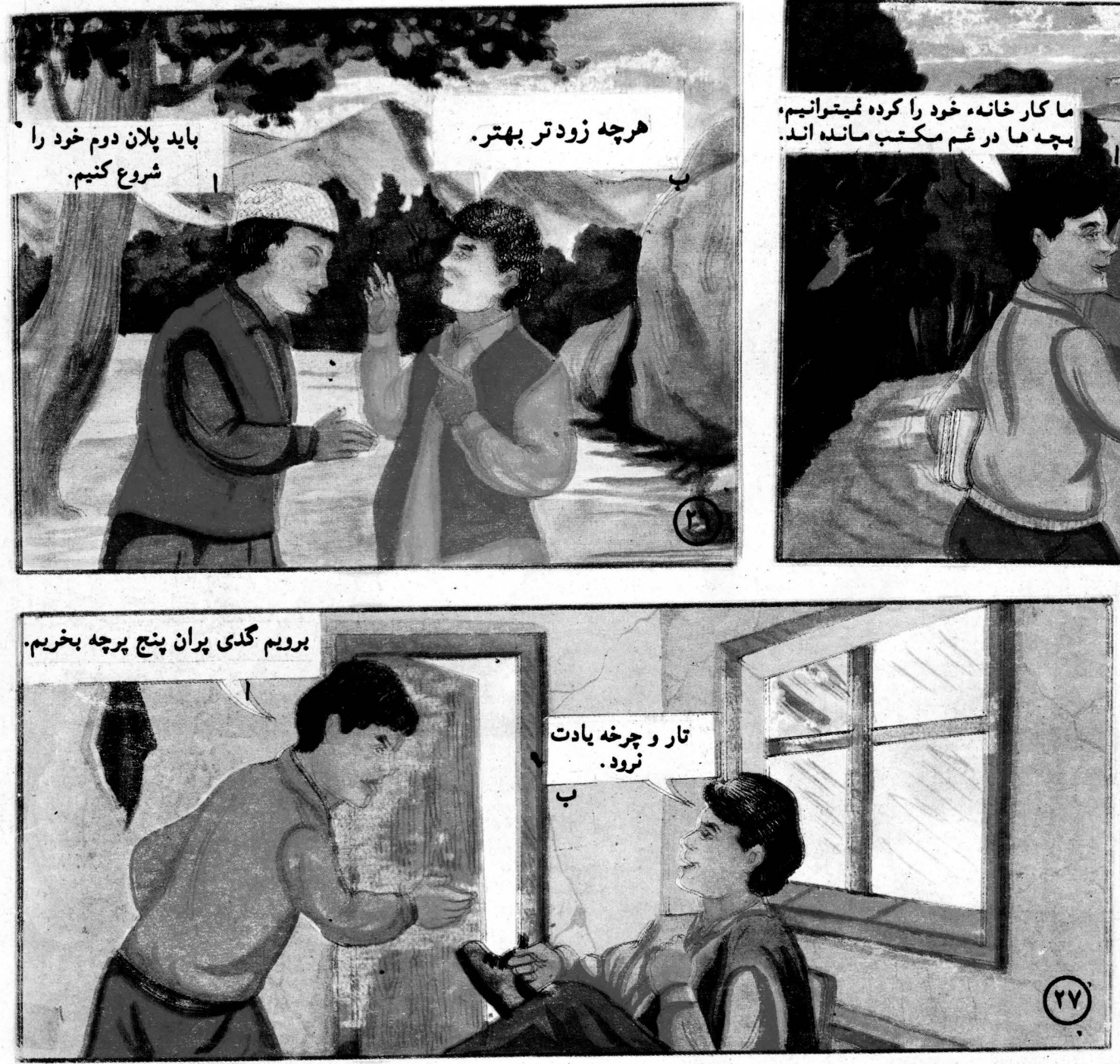

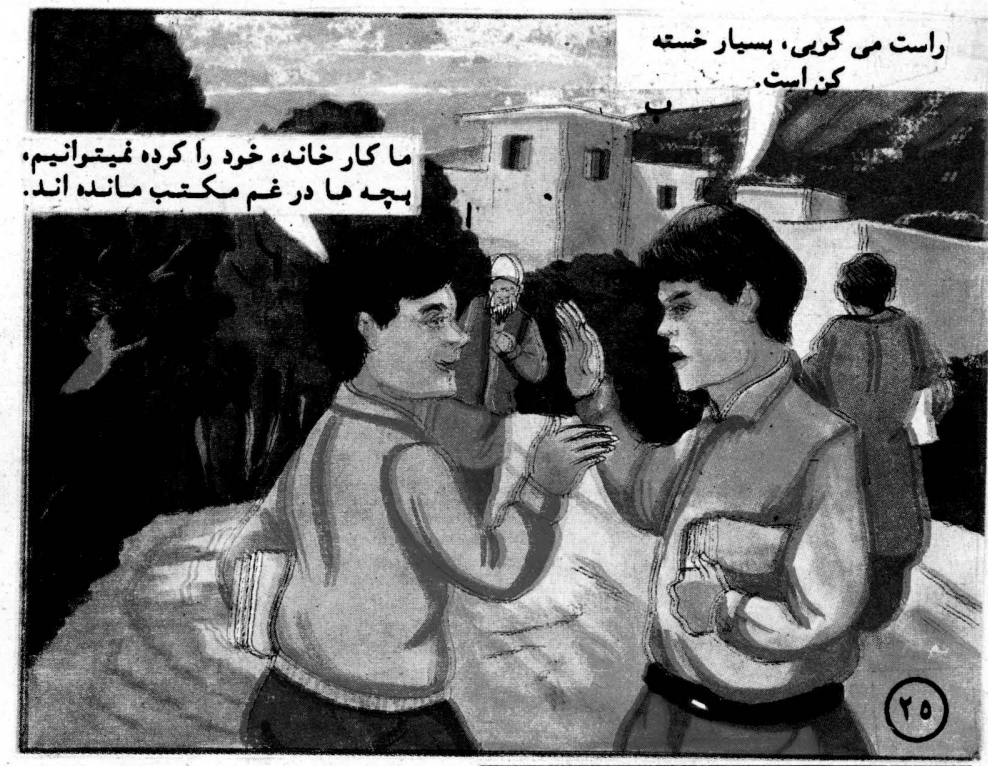

احمد وفريد كه بدر خود را از دست

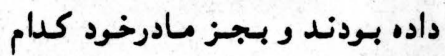

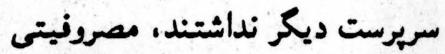

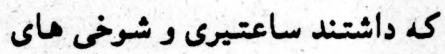

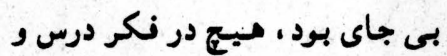

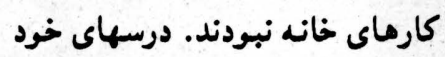

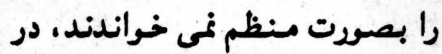
صنف بازيكوشى مبكردند و درو كارماي خانه به مادر خود كمبك بكرديك نكرده، وباعث آزار و اذيت او نبيز ميكرديدند.
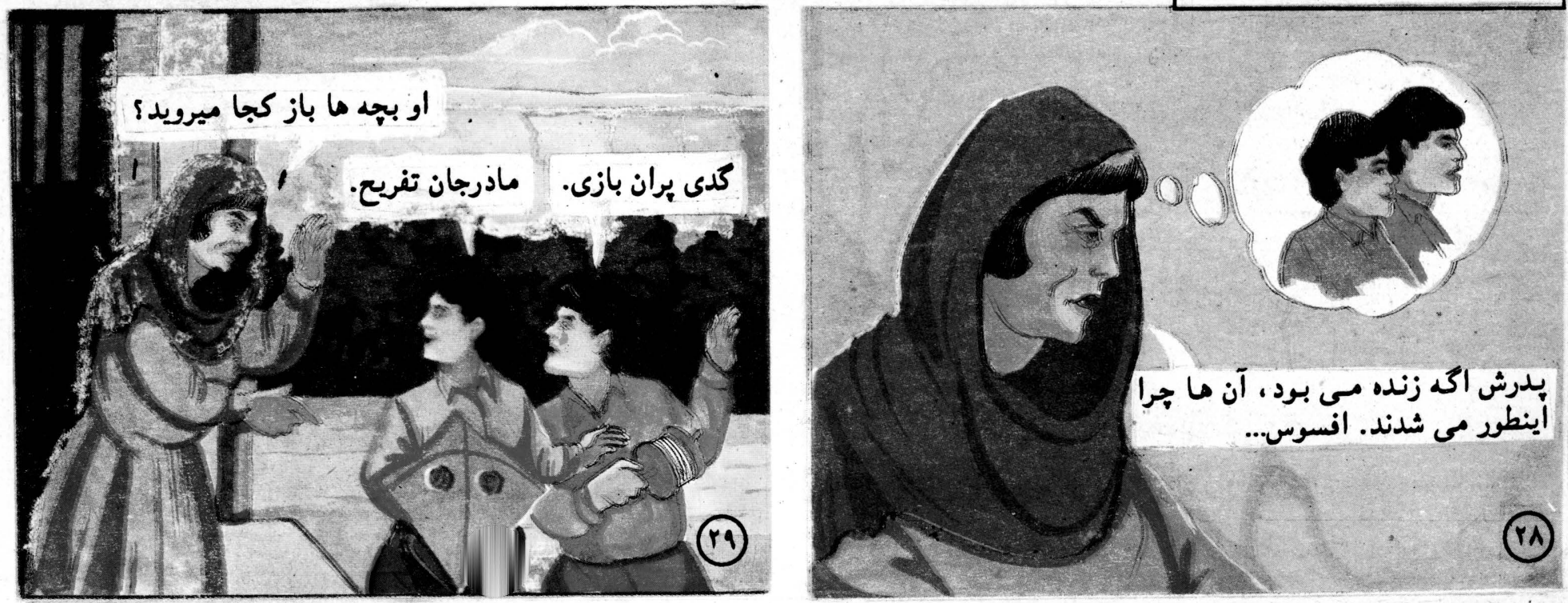


\section{أو تحت همت}

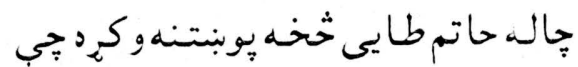

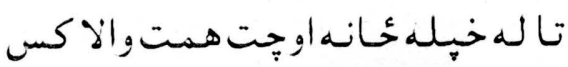
ليـلى او يادى اوريدلى؟ هغنه ئهواب

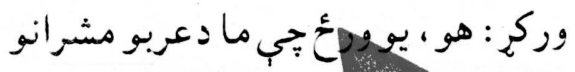

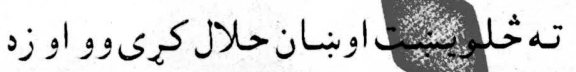

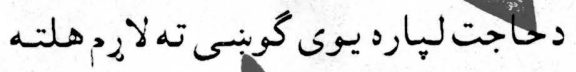

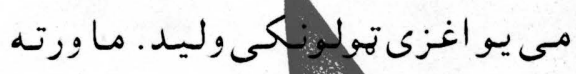

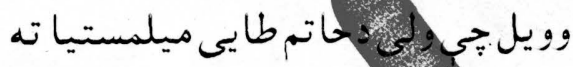

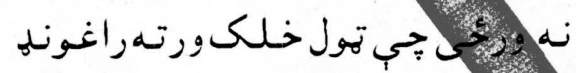

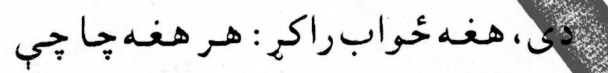

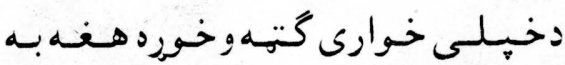

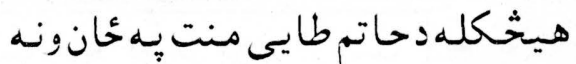

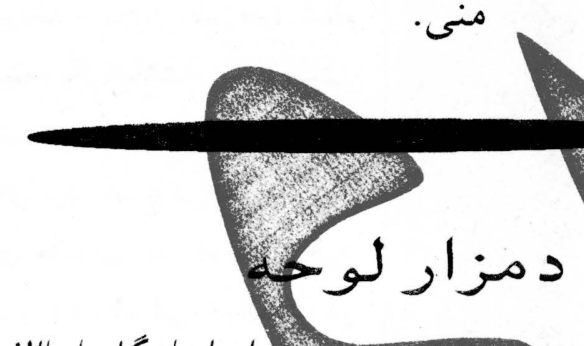

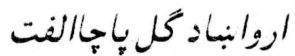

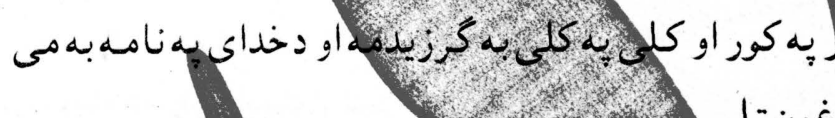

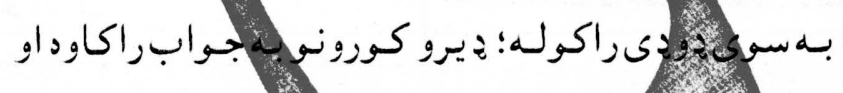

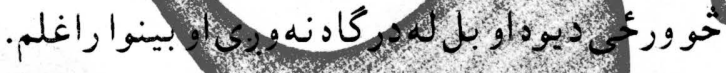

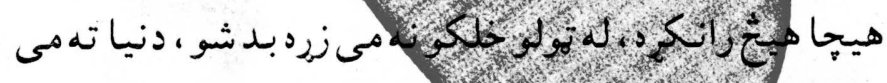

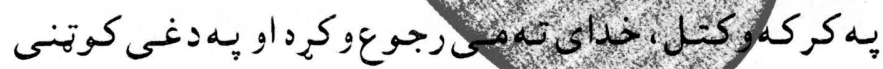
(قبر) كي يريوانها

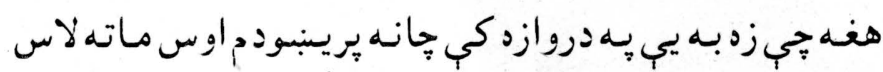

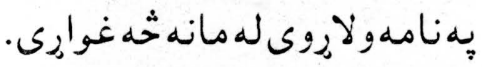

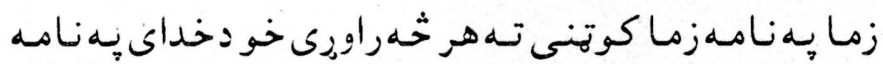

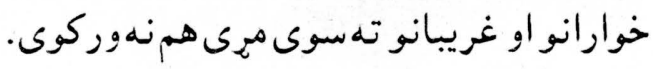

\section{غوره خـبـرى}

- دالله تعالى بلنى ته هميشه لبيك ووايهاو كله مو

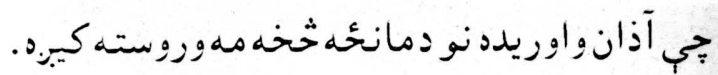

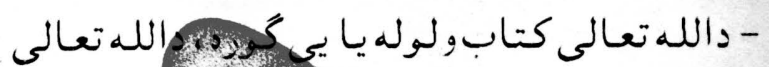

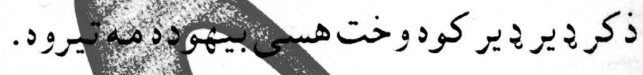

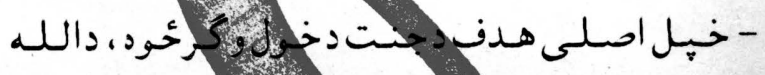

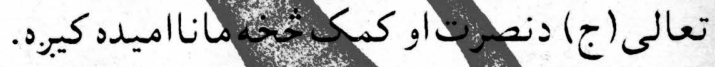

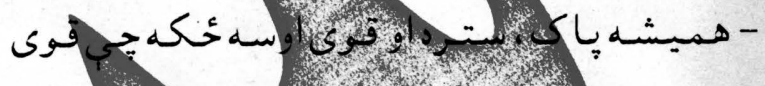

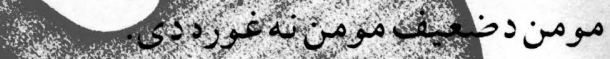

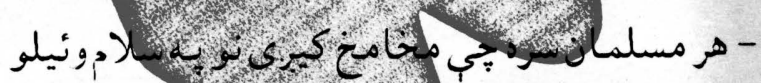

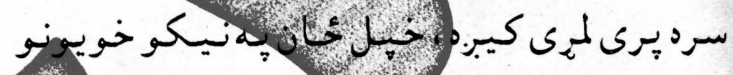

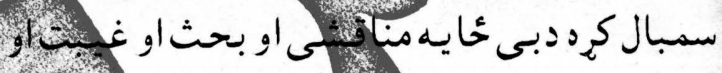

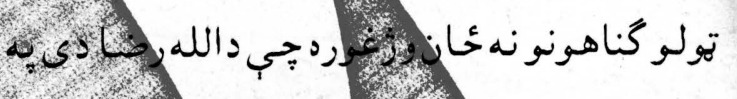

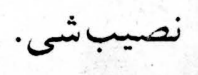

\section{بر}

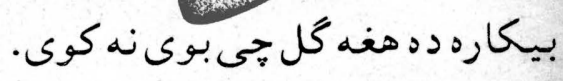

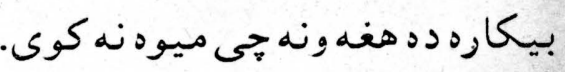

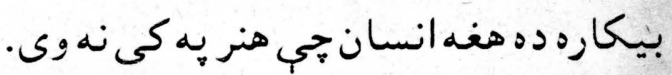

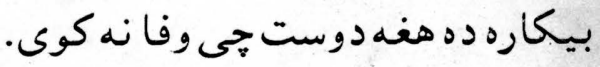

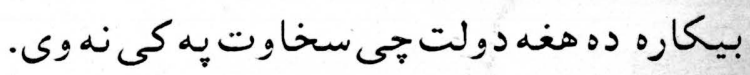

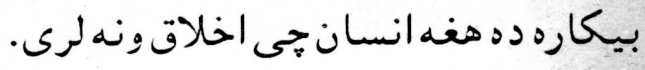

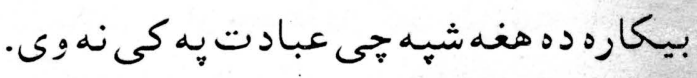

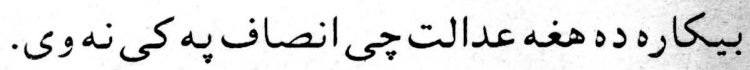
بيكاره ده هغه ميوه جيى خوندنه كوى دئ

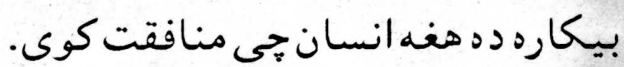

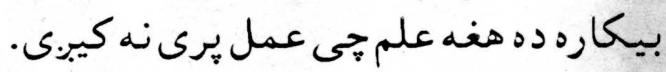

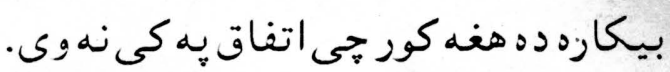

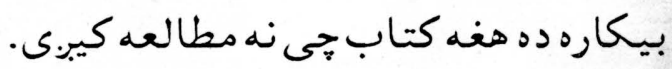
راليبرونكى: ضاء الله كروخيل 
(1)
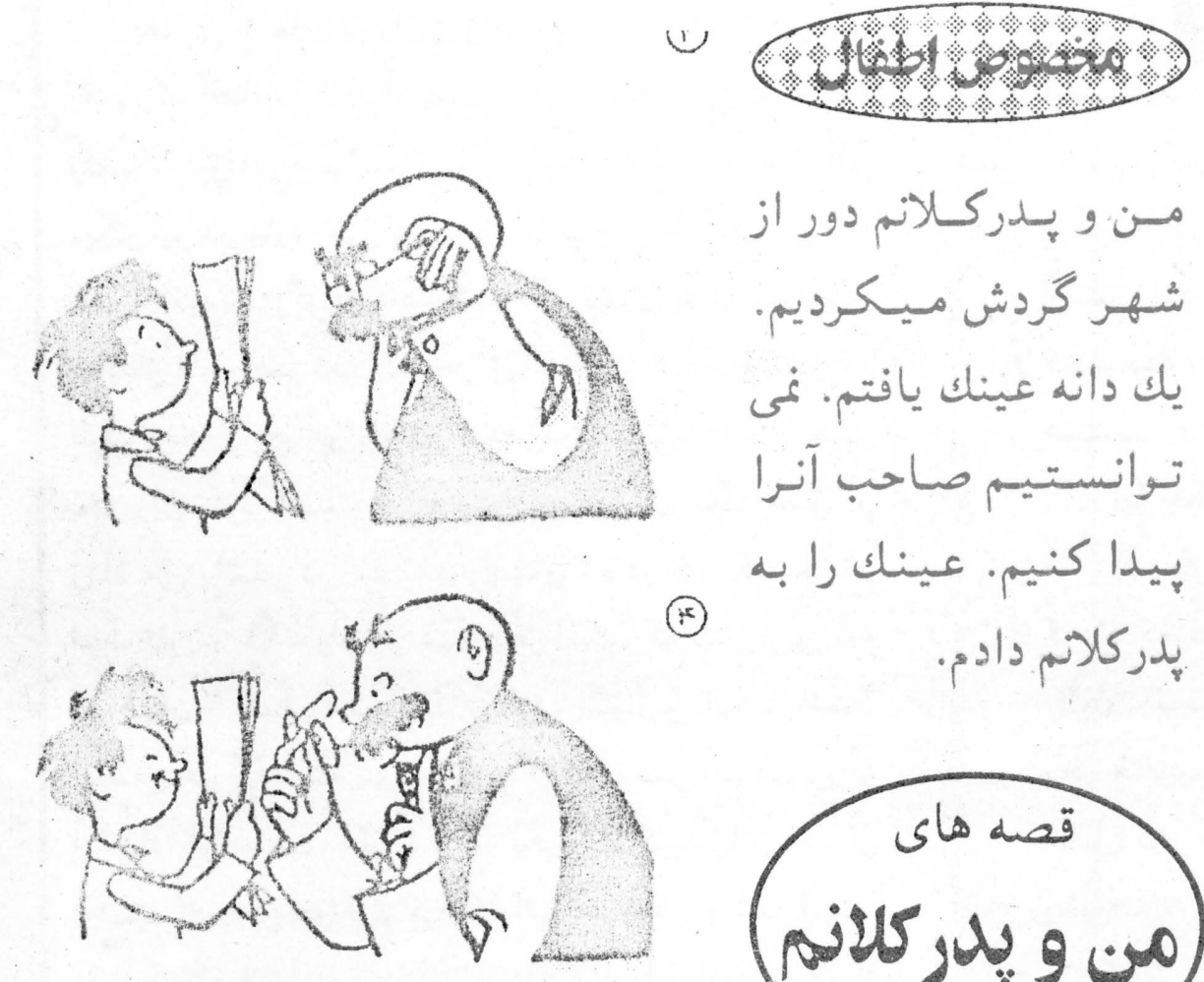

(5)

مسن و ،سلدركلانم دور از شـهر كردش مسيـكرديم. يك دانه عينك يافتم . نمى تسوانسـتيسم صاحب آنرا

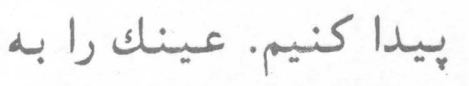

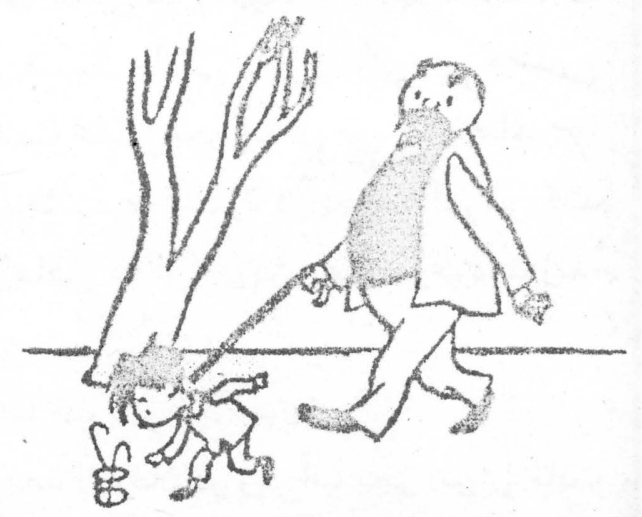

(4)

$$
\text { يدركالانم دان }
$$
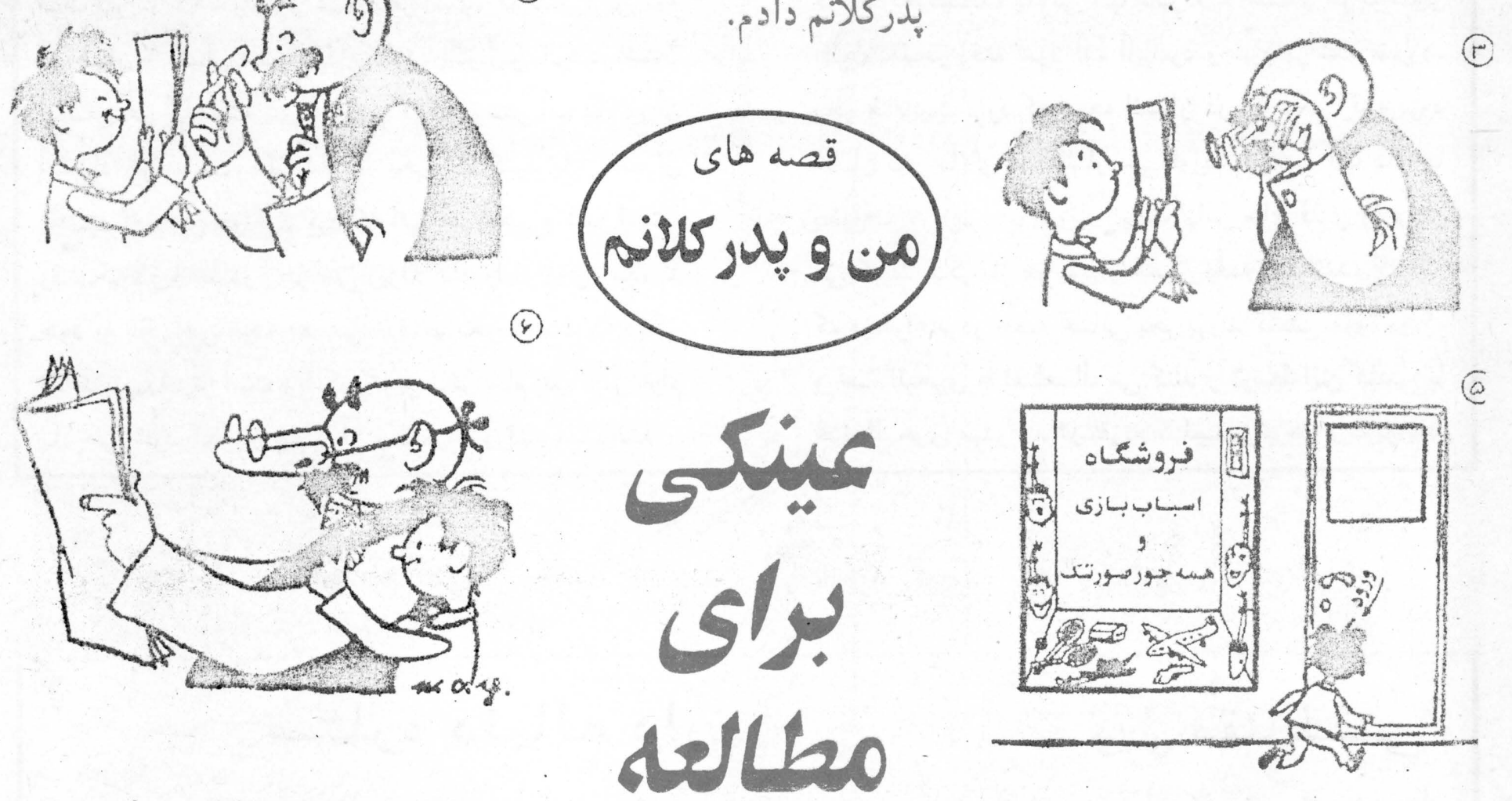

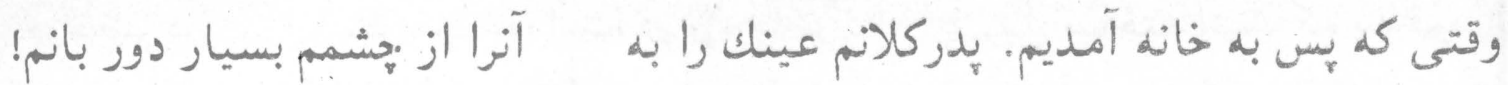

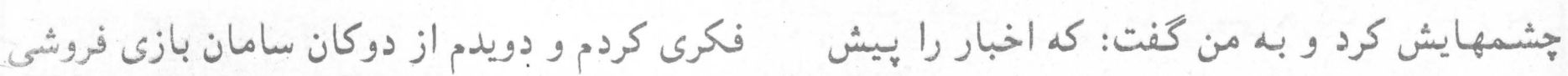

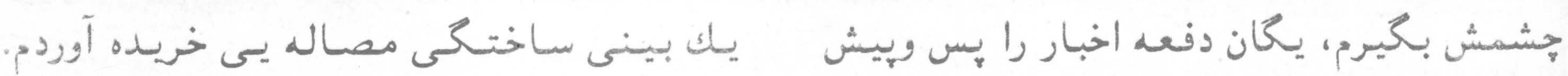

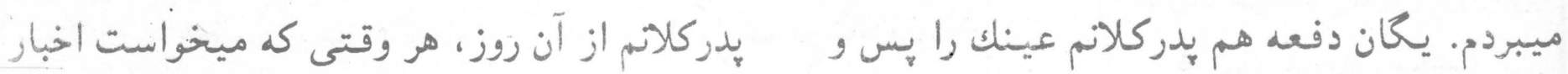

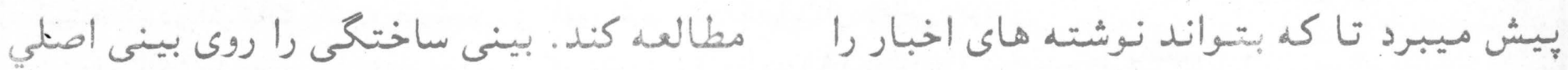

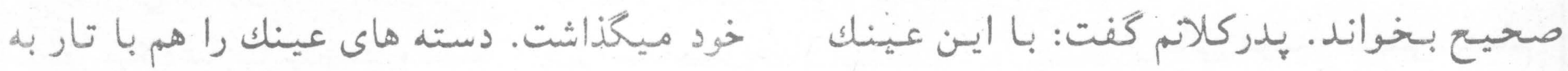

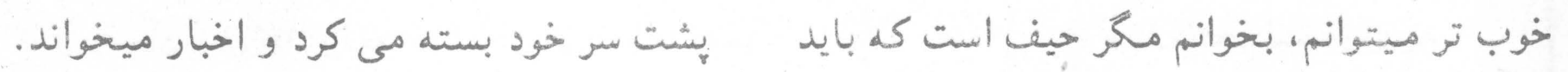




\section{(1)}

سال سوم شماره سى وهفتم سنبله IrVV

ماهى ما هم در آن جازندكى كرده نميتواند. در بسيارى از

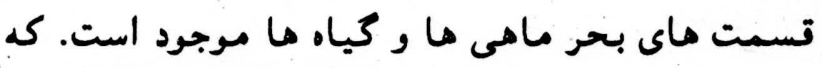

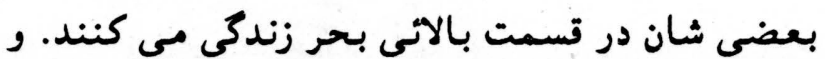

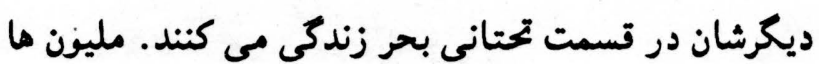

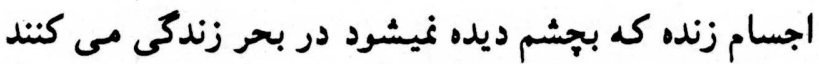

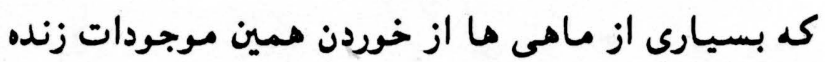

هستند.

آيا بفكر شما آب بحر سرد است؟

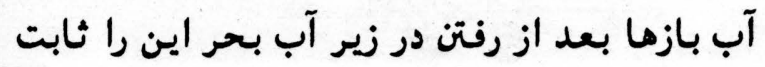

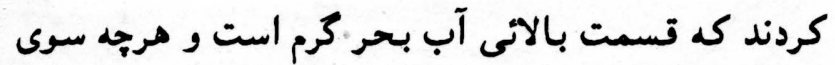

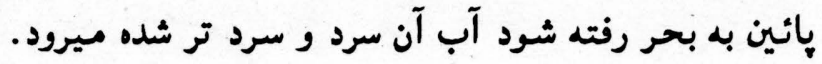

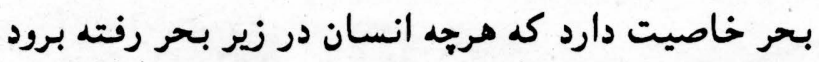

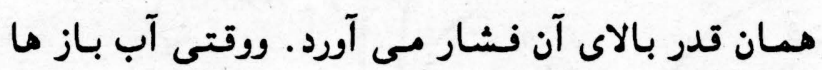

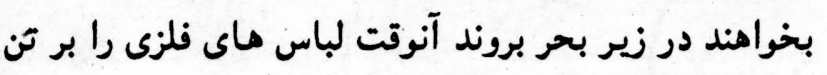

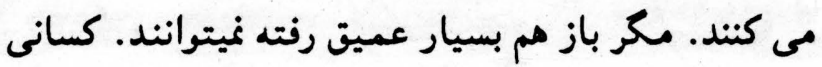

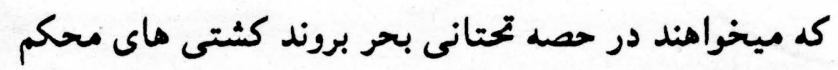

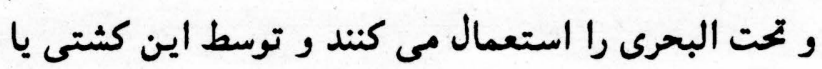

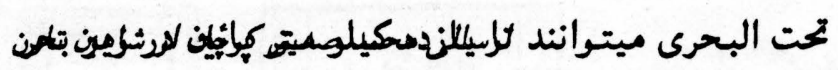

بعضى از ما بحر را از نزديك يا در تلويزيون ديده ايم

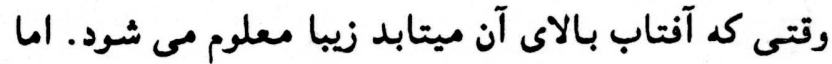

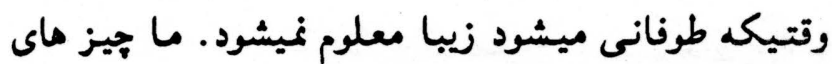

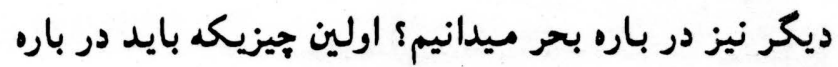

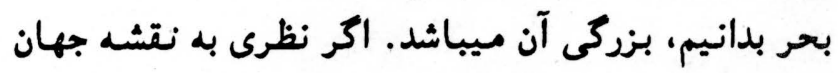

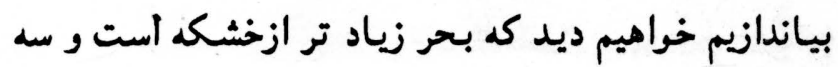

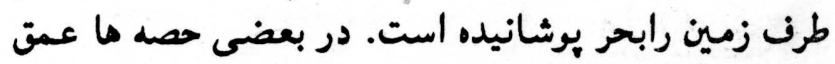

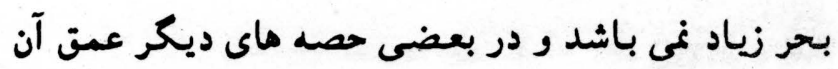

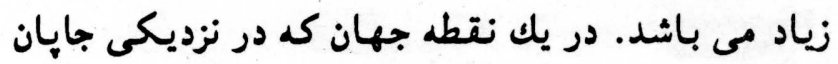

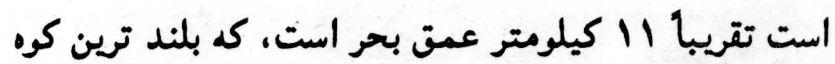

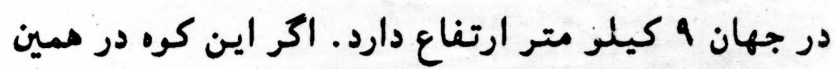

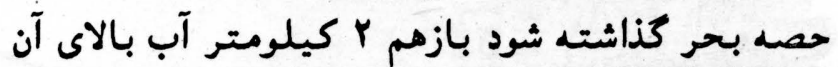

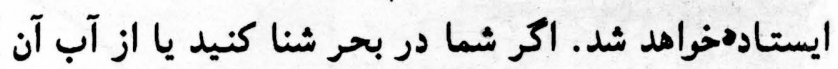

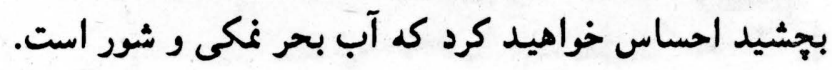

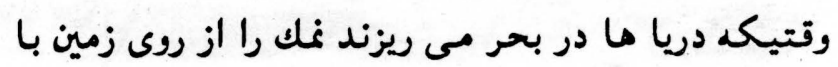

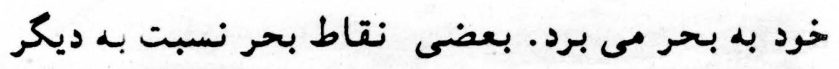

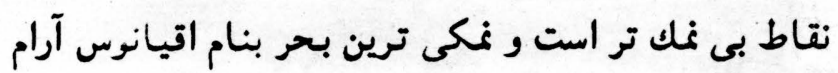

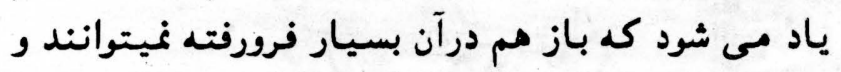

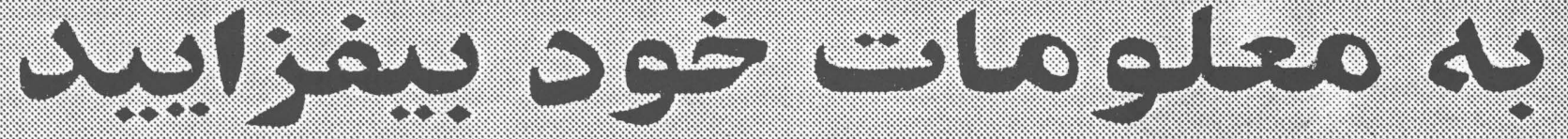

\section{ريل مقناطيسى}

يك كمـينى جرمـنى يك ريل سـاخته است كه بـه قوه مقناطيسى حركت مى كند و بـ بـ

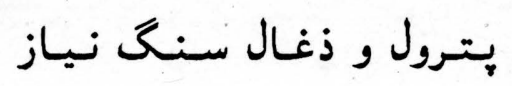

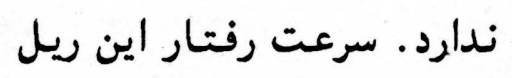

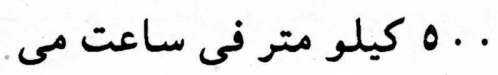
باشد. ارسالى فرشته صفتى متعلم صنف ينجم ليسه زرغونه

\section{ستا ره دنباله دار}

ستاره دنباله دار كلوله اي از كاز انكيز بزرگ در زمين است ولى امروز اين نظريه رد شده است. در حال حاض إن أنروز

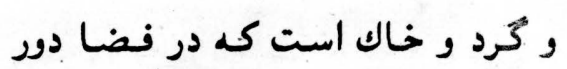

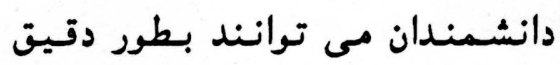

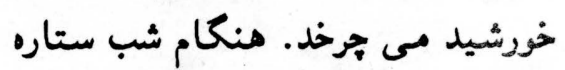

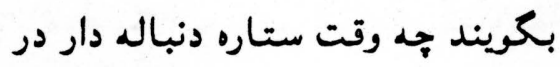
آسمان ظاهر خواهد شد، وندان معروفترين ستاره دنباله دار كه در سال مان ماي اخير

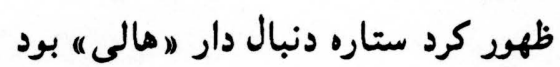

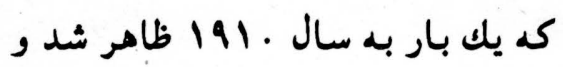
قرار است مجددا بديدار كردد.

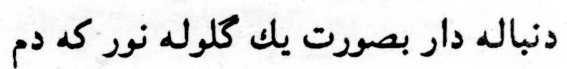

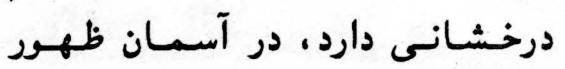

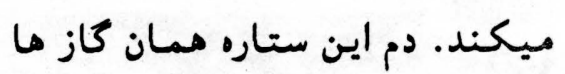
هستند كه در اثر تابش اشعه خورشيد

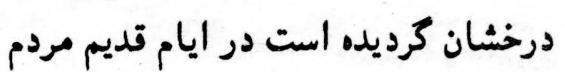
تصور ميكردند. يبيدا شدن ستاره دنباله

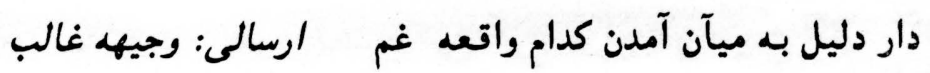




\section{ساعت تنبل هاعل}

\section{يكى از ساعت سازان ايتـاليا}

ساعت عجيبى براى بيدار كردن اشخاص

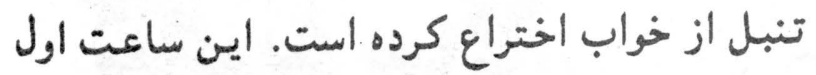

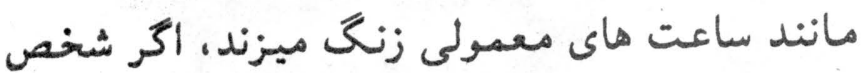

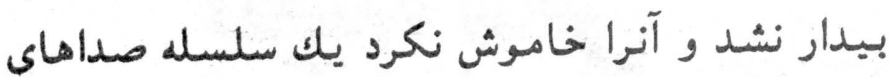
عجيبى كه روى فيته مخصوص ثبت شده مانند صداى

هارن موتر، عوعو سخ هاى خشمخين، صداى خيند

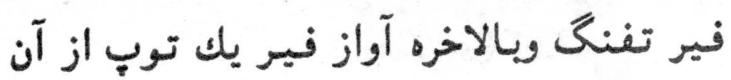

بلند شده و شخص خوابيده را بيدار

هي كند.

\section{جرا باقيانسوس اطلس}

درقديم اقيانوس سياه ميكُنتند

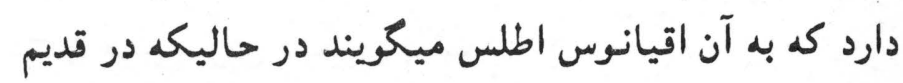

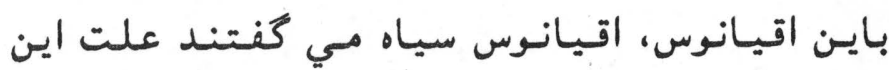

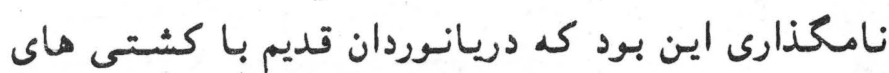

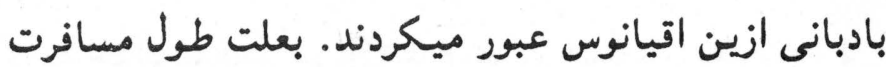

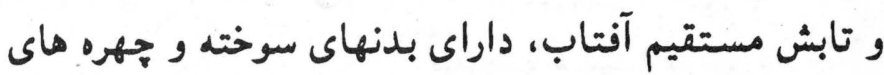

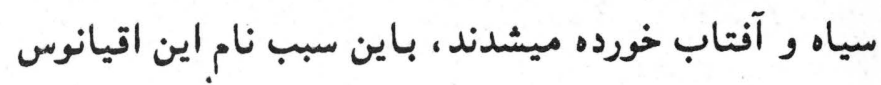
را سياه كذاشتند يعنى هركسى ازين اقيانوس عبور كند، سياه ميشود.

ارسالى احمد نويد متعلم صنف نهم ليسه استقلال حيات آباد

\section{UL:}

سيس هواى مصرف شده را خارج ميسازند

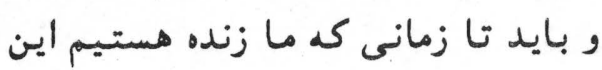

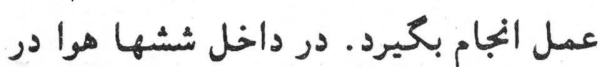
يك دستحاه از لوله هاى بـاريك بـخش

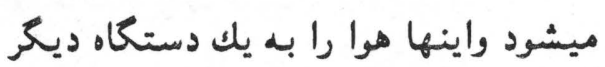

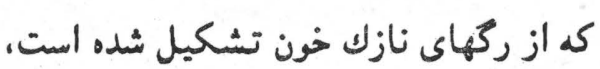

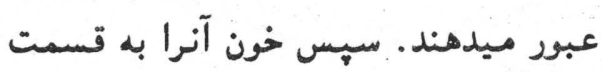
هاى مختلف بدن ميبرد و درحال كردش خون، آكسيجن را ميدهد وكاز ديكرى را به اسم بى اكسيدو كارين يا كاز كارينيك

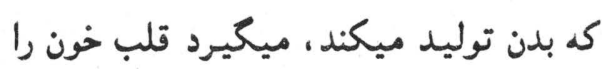

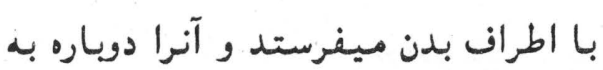
ششها باز ميكرداند در آنجا خون، كاز كاربنيك را يس ميدهد كه ما توسط تنفس آند آنرا از بدن خارج ميسازيم. ارسالى: حسينه غالب متعلم صنف شُشم مئم ليسه بى بعى عا يشه صديقه
يكى از اعمال مهمى كه بدون اينكه در باره

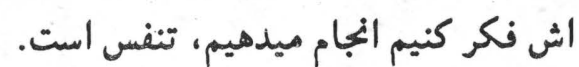

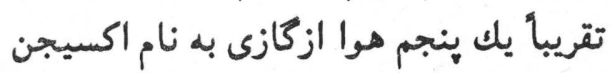

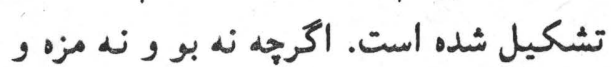

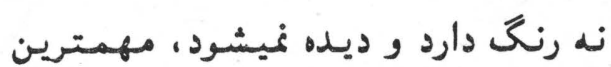

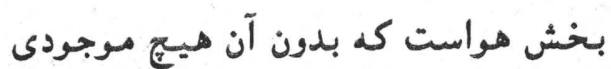

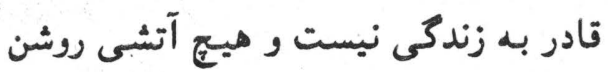

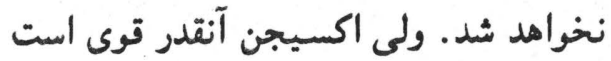
كه اخر براى مدت زيادى آنرا تنفس كنيم آندري بزودى مارا ميكشد. نيتروجن كه سه جهارم

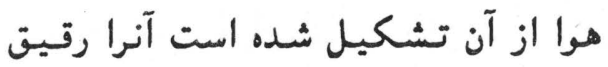

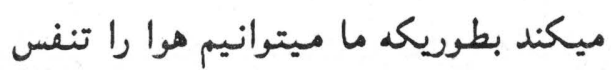
كنيم. براى اينكه آكسيجن مارا زنده نـهـ

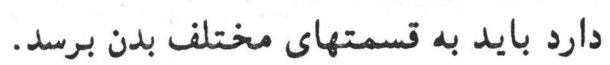

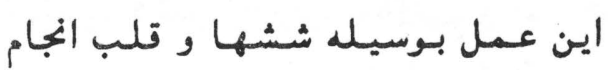

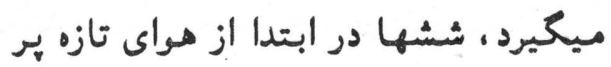
ميشوند.
وسيع ترين جزاير جهان جزيره /مساحت به كيلو متر جرئر

كروينلند . TIV009

VOV.0. مارنيو OAV.\&1 مادإناسكار OrEl.. سوماترا rY१^V. برتانياى كبير

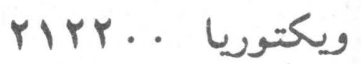
بزرگترين شبه جزاير محل /مساحت به كيلو متر بر ئرين مريع عريستان ع ....... VV.... اسكانديناوي نجيب الله ساهل از ليسه عالى امانى لئى 


\section{illos}

\section{كفته هاى دانشمندان}

بيوفائى دوستان را مى توان بخشيد اما نى توان فراموش كرد.

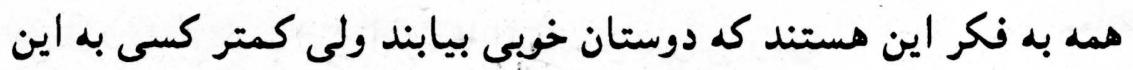
نكر است كه دوستان خويى براي ديكران باشند.

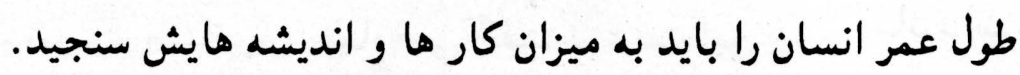

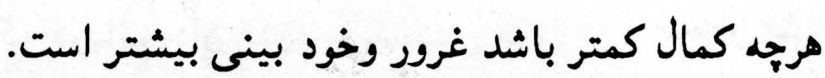

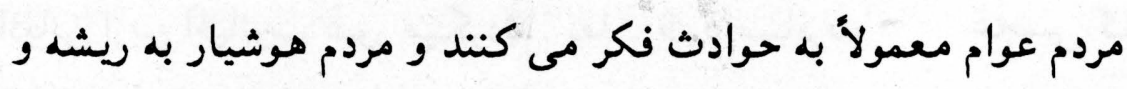

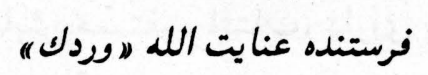

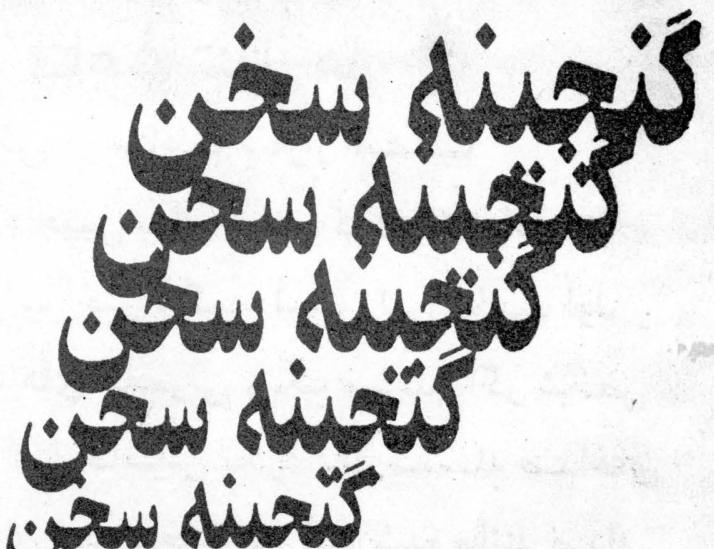
w disis
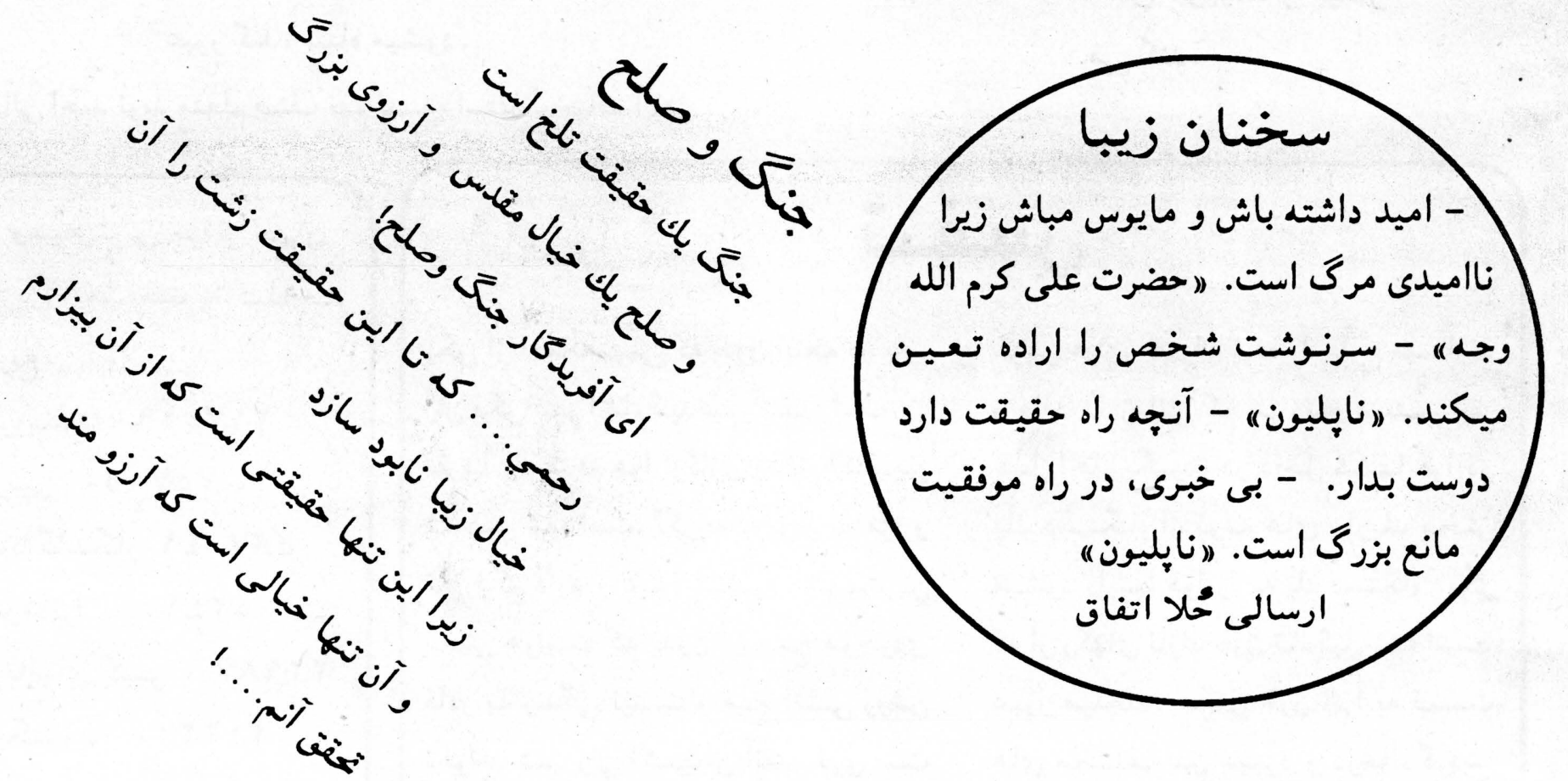

در وغكو جوانسمردى ندارد.

بخيسل راحست و آرامسش نسدارد.

خاموشى، برده بارى ودانش از نشانه هاى دانيائى است.

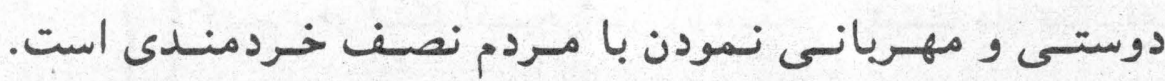

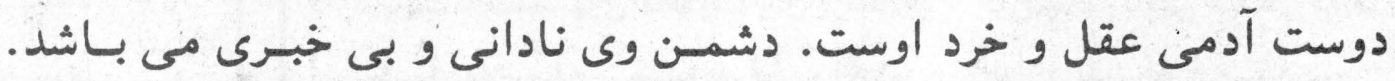

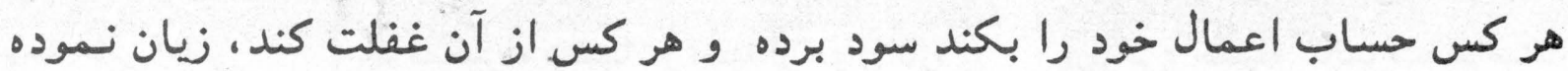

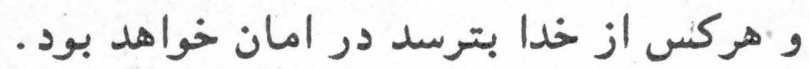




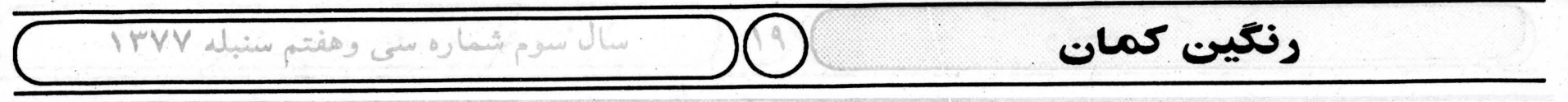

\section{|صفحسات خمودنا||}

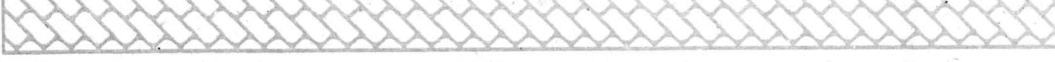

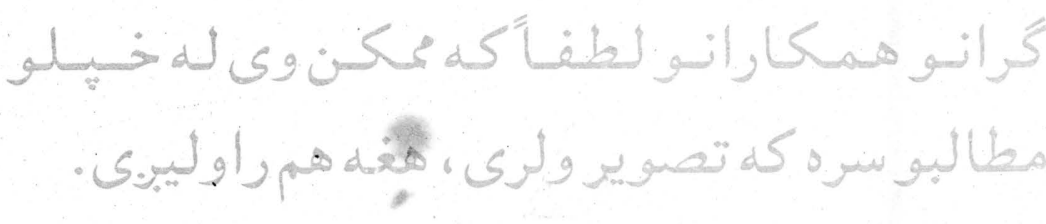

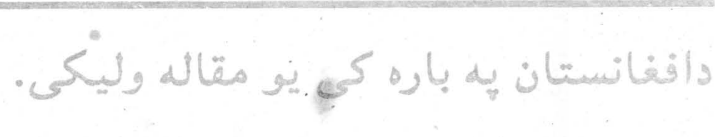

نام من :

نام بدر : سن : صنف : مكتب : آدرس :

- خويترين و تازه ترين نكاهيات و جالبتـرين

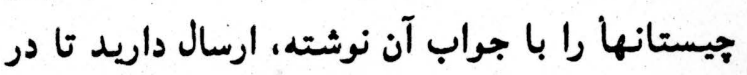
مجلهء خود تان به نشر برسد. 
رنكي

(1)

IrVV سال سوم شماره سى وهنتم سنبل

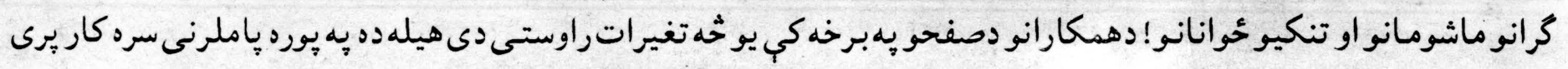

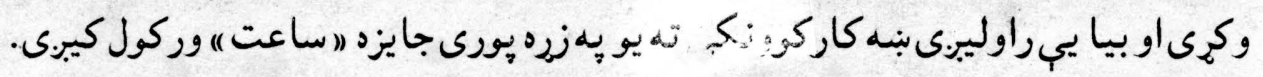

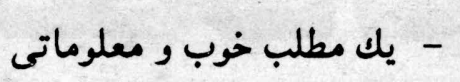

-

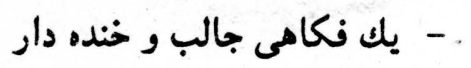

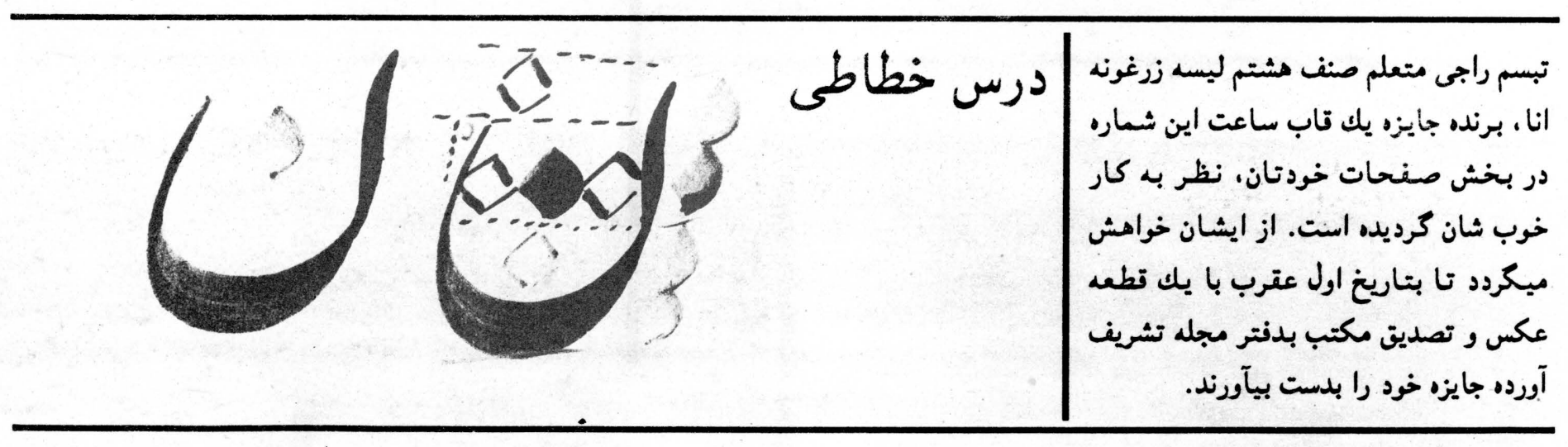


اى بعد مادر طفل از مغازه خـارج

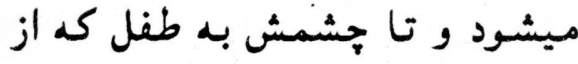

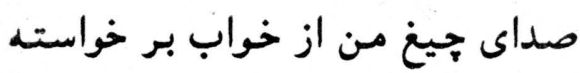
است، ميافتد، رويش را بطرف من إن بران

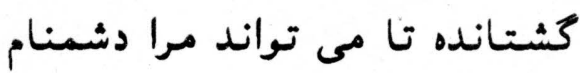

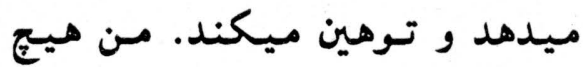

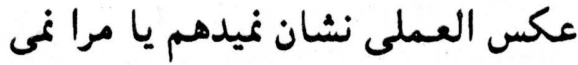

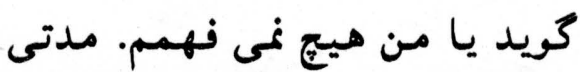

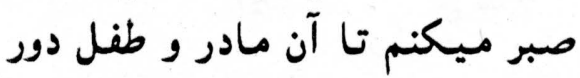
شوند. بيش از اينكه باز هم دهنم را

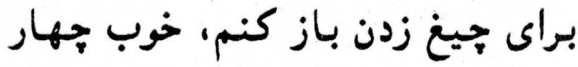
طرف خود را مى بينم وقتى خاطرم

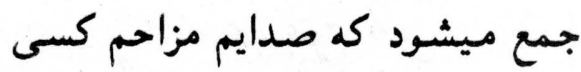

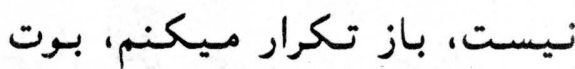
يالش، بوت بالش. ") مكر فكر ميكنم

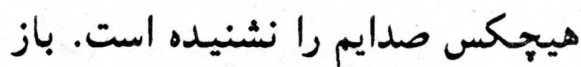

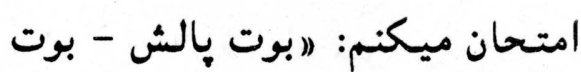

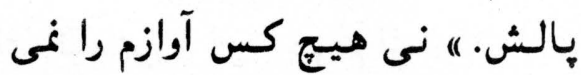

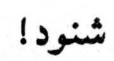

مدتى ميكذرد، نمى فهمم جقدر

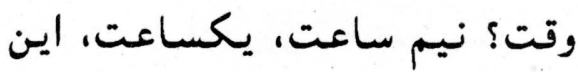

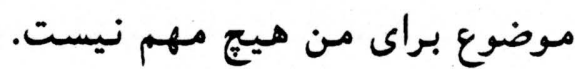

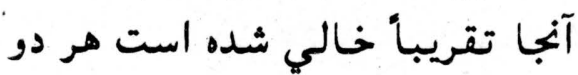
دستم در جيبهايم هست. جشمانم را

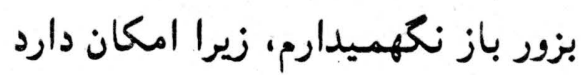

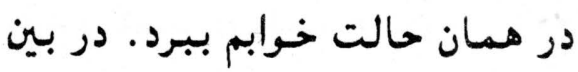
خواب و بيدارى متوجهء موتر سياه رنغ بسيار لوكسى ميشوم كه در نزديكى من ايستاده شد. يك نفر از

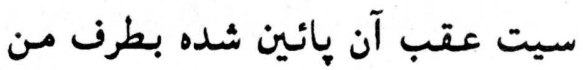
ادامه دارو آمد و صدا كرد:
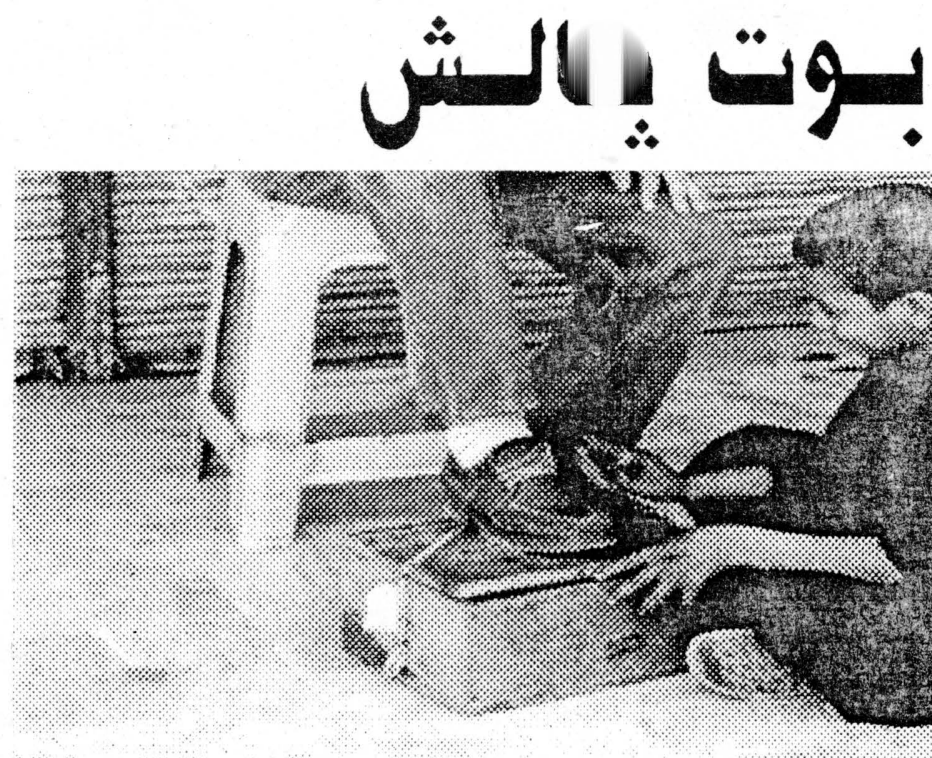

- ارسالى: آرزو بهار

ميسازد. آخر شما بكوئيد جطور ميتوانم فردا صبح با شكم كرسنه اينطرف و آنطرف بدوم تا براى نان

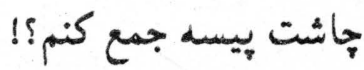

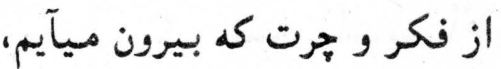

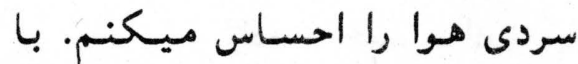
اينكه هنوز يكماه به زمستان مانده،

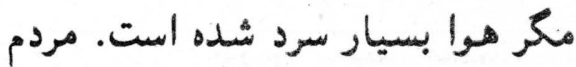
بسيار با عجله و تيز تيز به اينطرف

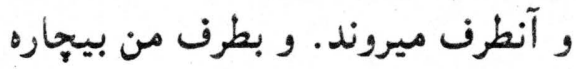

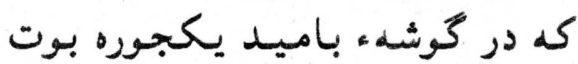
جتل نشسته ام هيتج توجه ندارند. فكر ميكنم اصلاً مرا نمى بيند ازين توجه ندارند خاطر تصميم ميكيرم موجوديت خود

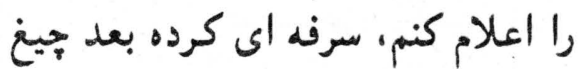

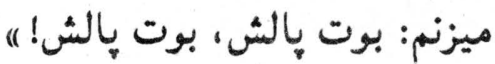

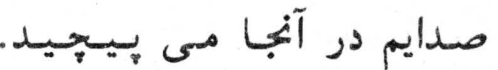
ناكُهان خيخ طفل خوردى كه دريك ركشاى طفلانه مقابل مغازه ء ايستاده است، به آسمان بلند ميشود. لحظه
ساعت هشت شب، وقتى كه هوا

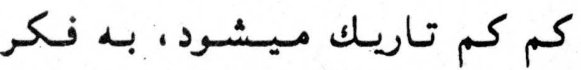

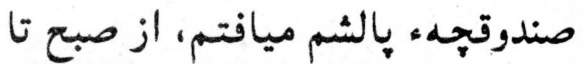
حال زيادتر از سه بار بآن دست نزده يأن

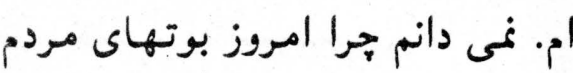
پاك است و هيجـس براى رنح كردن

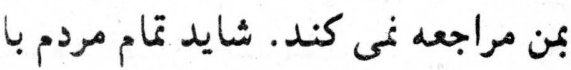
يكديكر فيصله كرده اند كه من بايد مند مردي

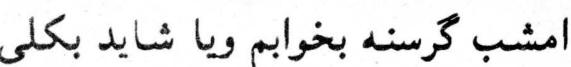
فراموش كرده اند كه بوتهاى خود را بحر

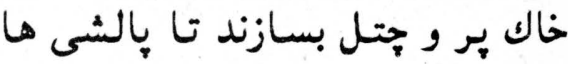
هم نانى بخورند! خير فرقى نمى كند. مسئله اينست كه امروز من تنها سه

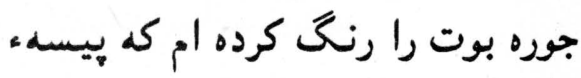
آن نان جاشتمب را كفايت كرده است. ازين خاطر اخر جند ساعت بعد كار را ختم كنم، هيج بيسهـ ديكر براي نان

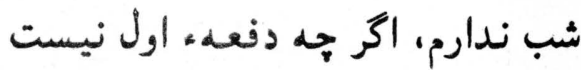
كه مجبور ميشم شب كرسنه بنخوابم. مكر فكر فردا صبح است كه بيحالم 


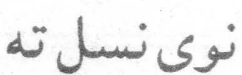

غيرتى زوى دافغنانه

ائوارثدبلخو بروانه

دكندهار اصلى جانانه

$$
\text { دمشرق غزنى لغمانه }
$$

دهرات هلمند گوهره

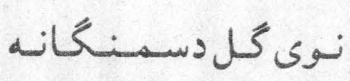

ديكتيا كابل زامنو

دكونـي دغرو توفـانه

دبت شكن محمود اولاده

دزؤندنسل اوسامانه

جى جسبا مونبر ياتىنهيو

دغيرتووئهنشانه

جى سبا مثمر نهال شى

بمكتار دهمنوعانه

دوطن يه حال نظر كر.

كورنخومرددى بريشانه

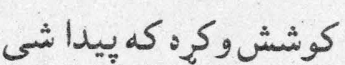

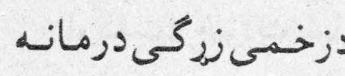

$$
\text { ترحمزردهوى يمكاردى }
$$

وويريبرده لـهرحمـانسه

دمسكين ملت بِ كارشه

" قتيل ) وائىنوئوانه

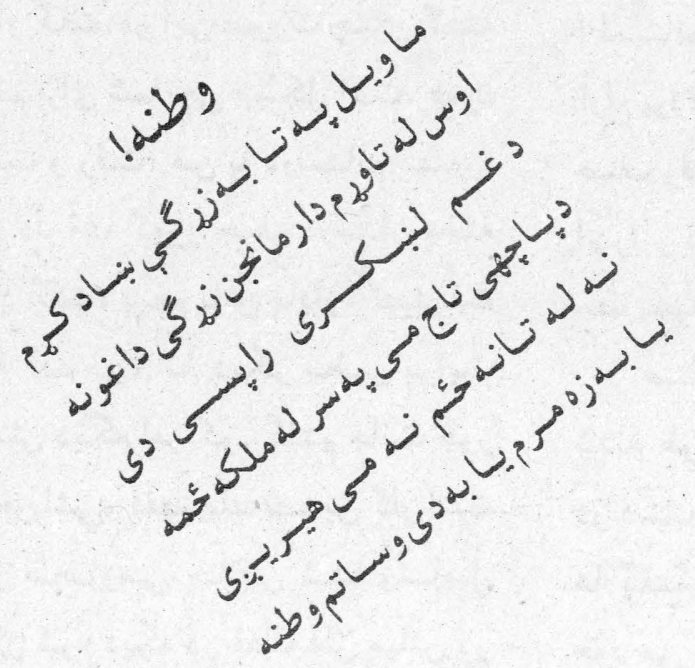

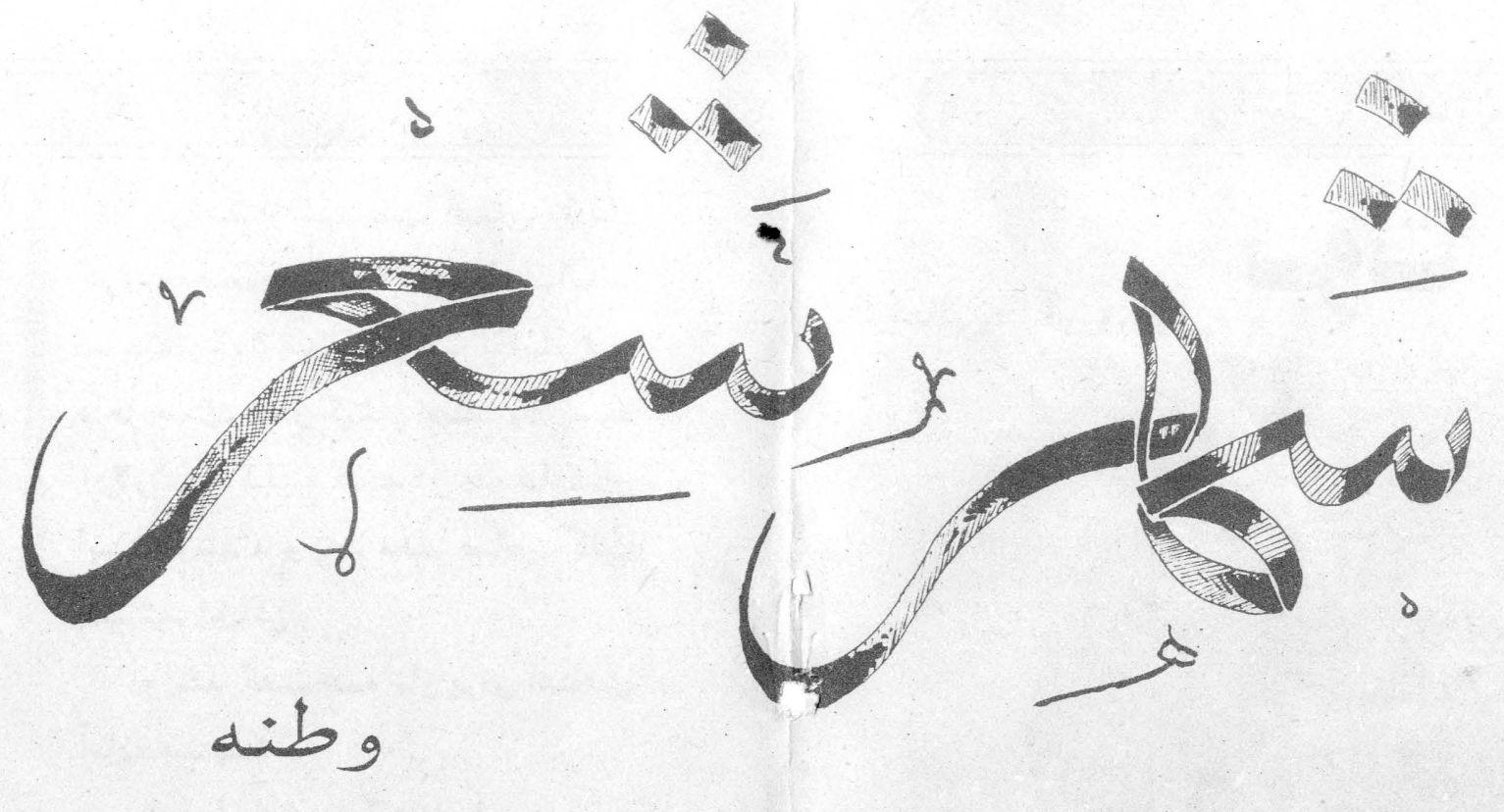

كلهبهوي هغنهساعتجي زمدرئموطنه

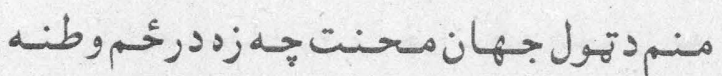

ددى جلاوطنزوندوندسبكاوىنه توبـه

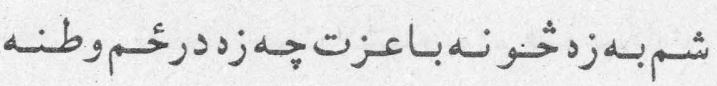

باده! ايرى مى دوجود ، وطن ته يوسمهزما

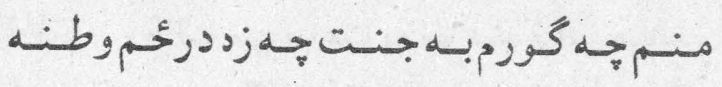

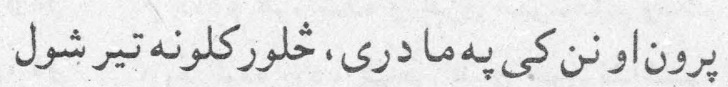

ريبتيا به تيرشى دا قيامتهدزندورئموطنه راليبرونكى: مُلااتفاق

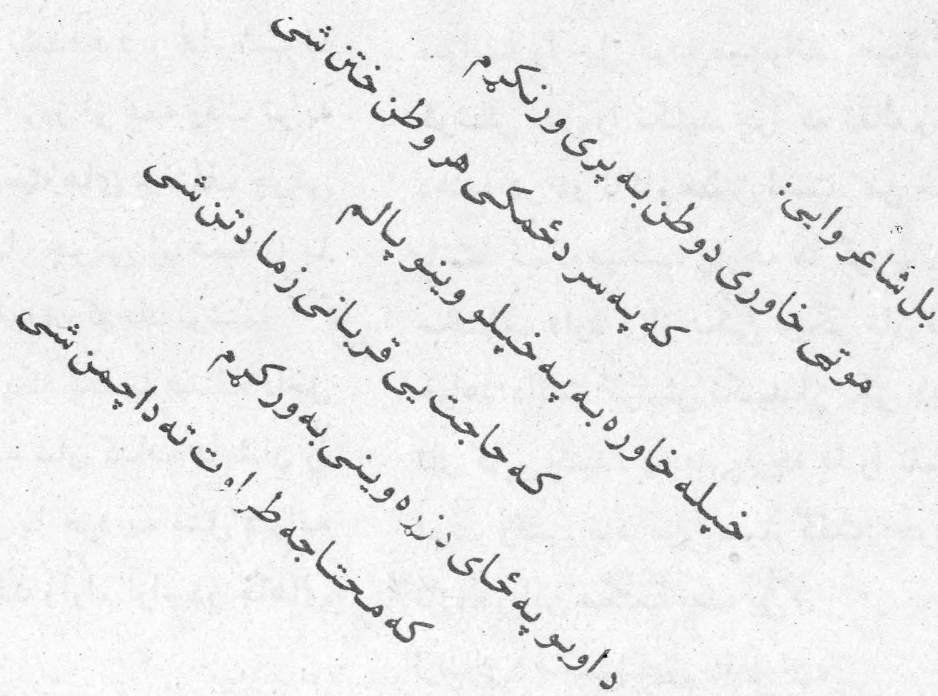

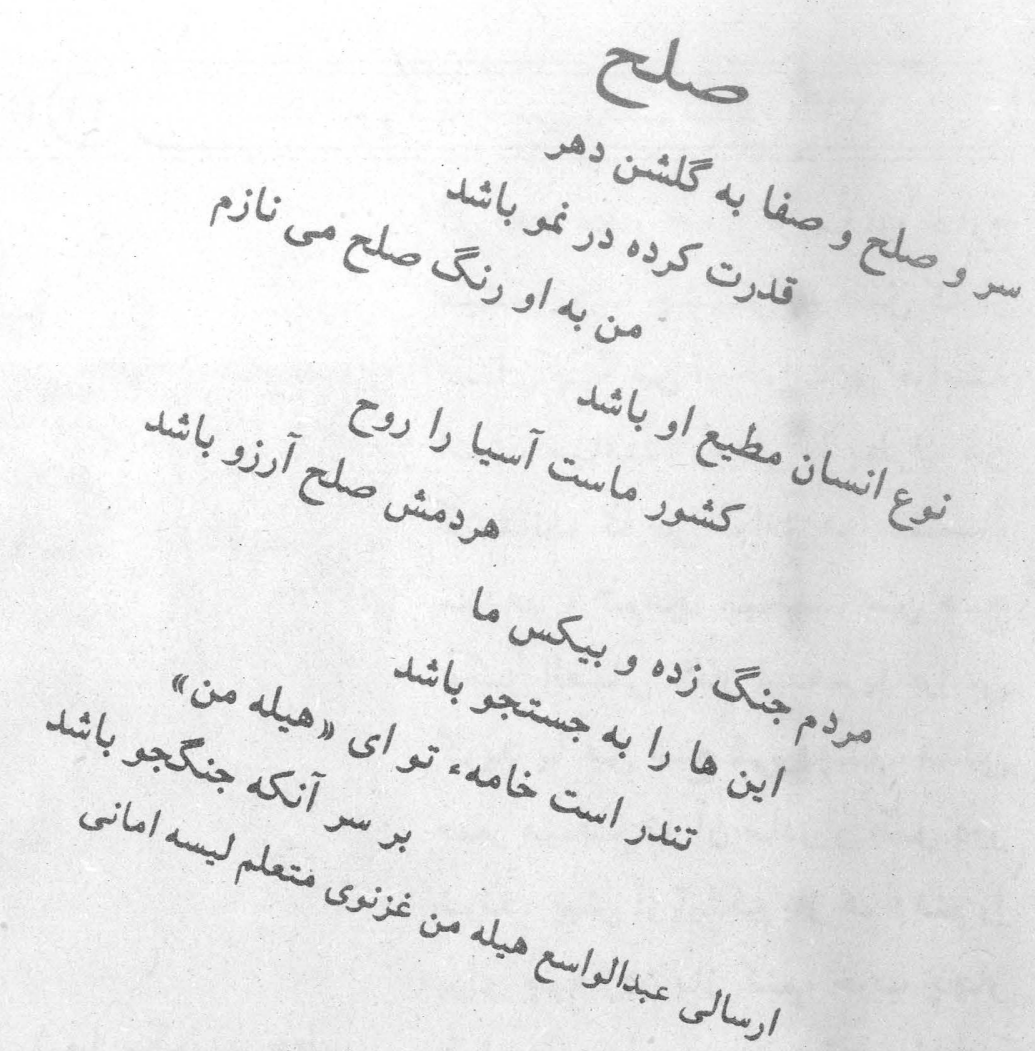

ميهن من

درس مادرس كوشش وكار است
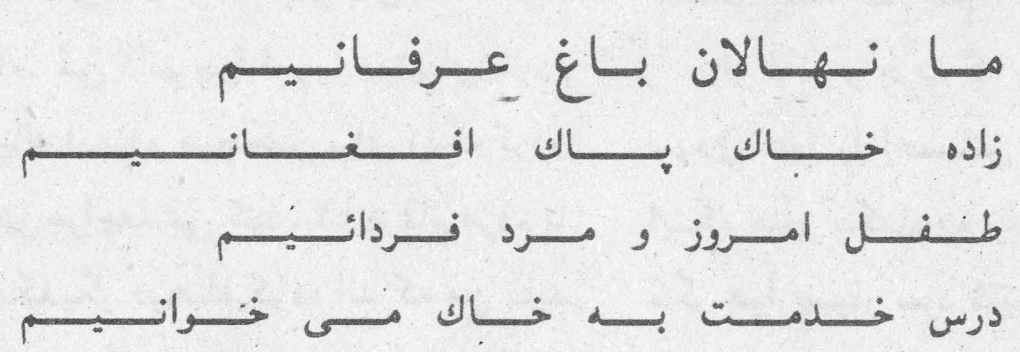

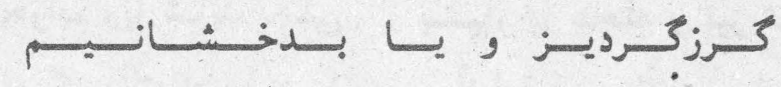

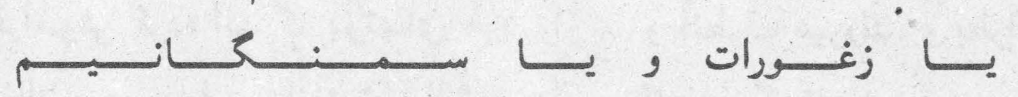

3

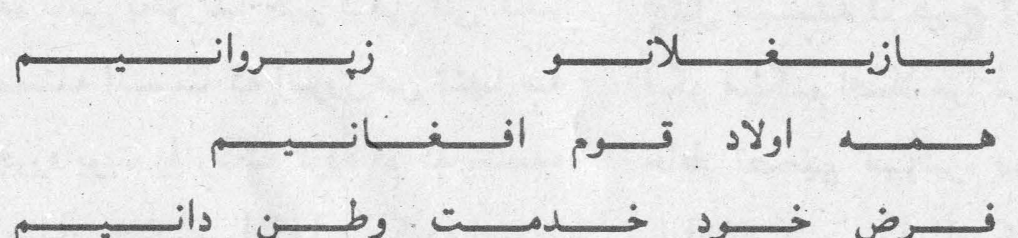

خاك ماخاك سبزوشاداب است صاحب نعمت فراوانيم

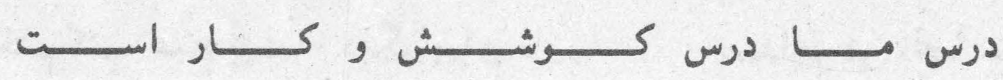

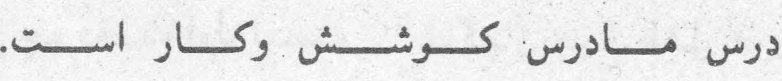

نى از $3 ل$ ونى جهمن سرايم نى سنبل ونس سمن سرايم اوصاف تو اى وطن سرايم

اي هستى و اي وجودم از تو تو وطير

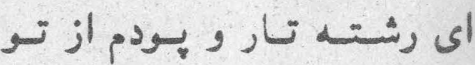

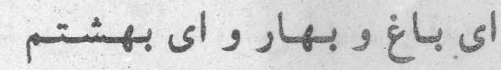
اي روز نـخست سر نوشتستم

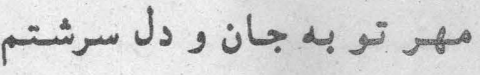
تخم عشتق به سينه كشتم

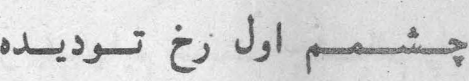

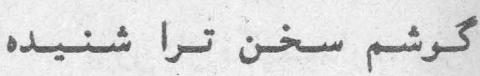

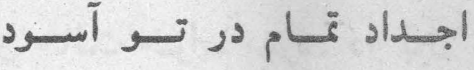

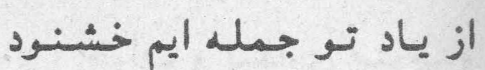

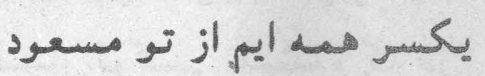
حاصل همه راست از تو مقصود

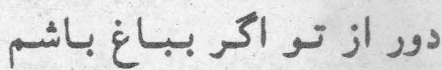
جون لاله تريسن داغ باشم باشم هركا، كه مسن سخن سرايم 
من هـم از شرم آنها كتـاب را بـاز

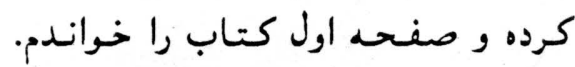

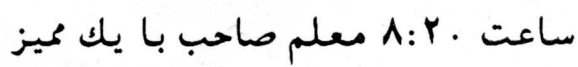

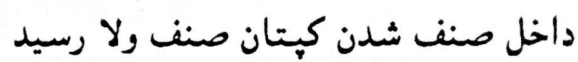

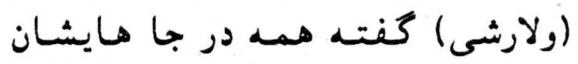

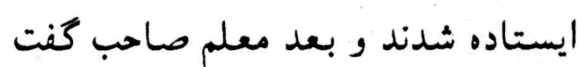
بنشينيد شاباش. و بعد گفت همه تان براى امتحان

آماده هستيد؟ و بعد كن همه با يك صدا كفتند: بلى ماره

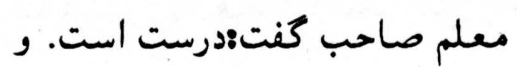

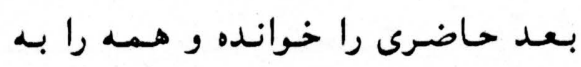
حساب حاضرى در حويلى مكتب تنظيم

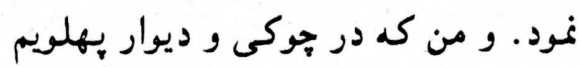

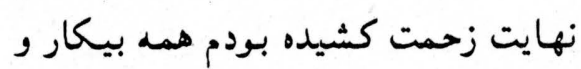
بى فايده شد. و بعد تمام كتاب و كتابحه هاى ما و مجله هاى مارا هم جمع كردند.

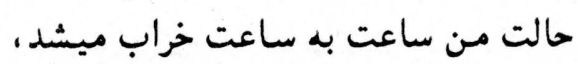

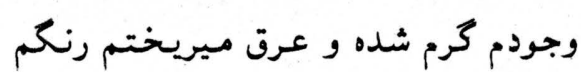

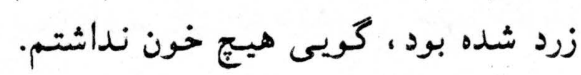

$$
\text { دست و هايم ميلرزيد. }
$$

استاد كفت: سوالهايتان بى نهايت آسان است. اكر كسى صرف روز مره در

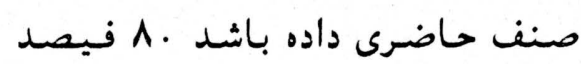

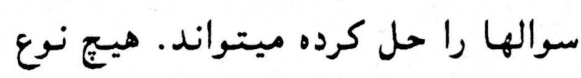
كوشش نقل را نكنيد جرا كد نقال ونقل دهنده هر دو ناكام مطلق است. من خودم

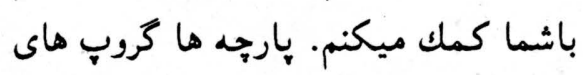

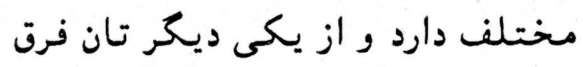
خواهد داشت كوشش نكنيد از يكى ديكر تان كابى كنيد. و بعد بارجه ها را تقسيم نمود. وقتى نزد من رسيد كفت: خودت ونيد تازه در اين مكتب آمده يى؟ وفي نزي ارسالى: محمدشفيق " (فقيران"

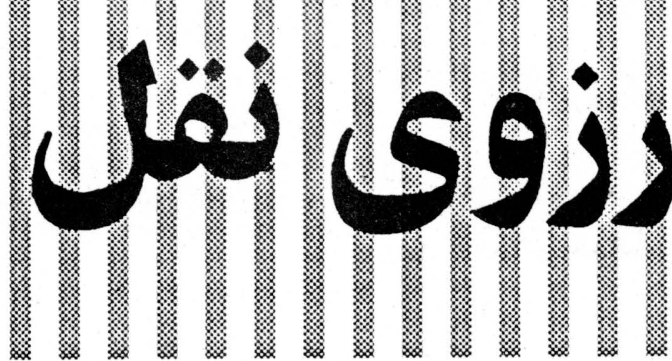

نقل خو مرا ميشناسين؟ همه كفتن: آ بادار بلى و با آراز بلند خنديده كفتند توخو در نتل جوره ندارى.

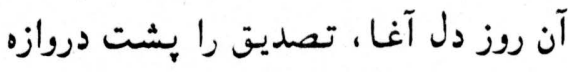
خانه ما آورد ومن هم فرداى آن تصديق

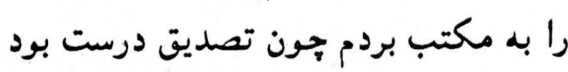

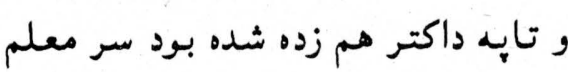

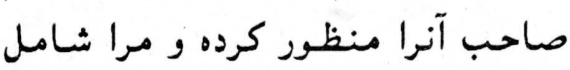

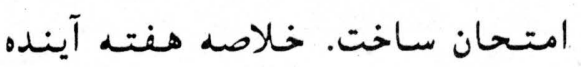

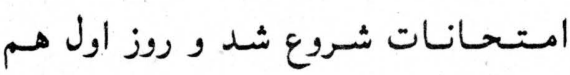

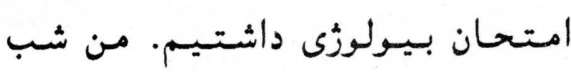
امتحان تا ناوقت شب تنها درو يك دئ اتاق نشسته و تمام گوشه و كنار كتاب راب رادر

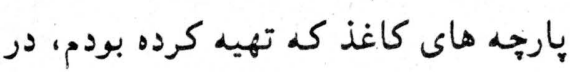

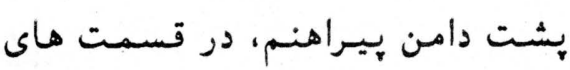

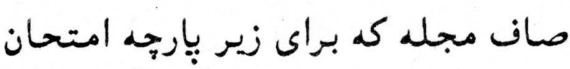

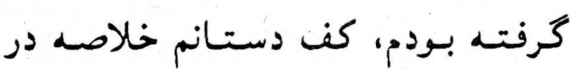
قسمت هاى مختلف جا بجا نمودم بان با آنهم

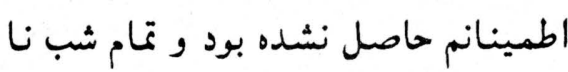

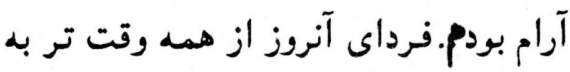

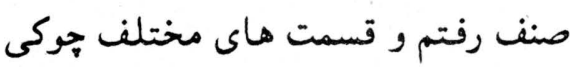

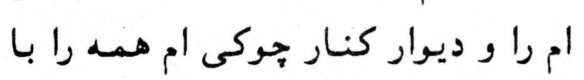
خط بسيار ميده ميده وكوجك نوشتم. صنفى هايم يكه يكه به صنف داخل

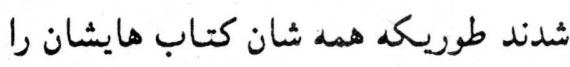

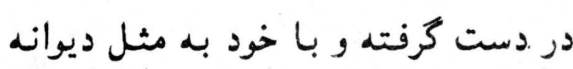
ها كفتار ميكردند وآرام آرام در جاهاى دردي خود مى نشستند.
ساعت دوازده و نيم بعد از ظهر بود و هو ا هم خيلى كرم · من با دوستانم كي

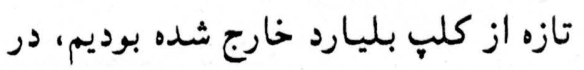

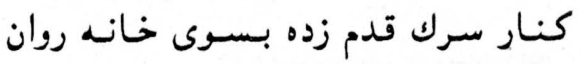

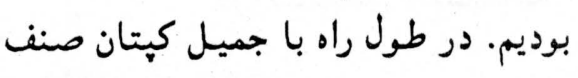
ما روبرو شدم. از او يرسيدم درمبكتب

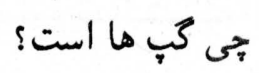
كفت هيتج خير و خيـرت درسها

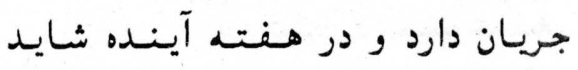
امتحانات شروع شود. كفتم. راستى ؟ جطور كنيم، من بيايم يانى؟ اوكفت: خودت شايد محروم شده باشى جرا كه غير حاضرى هايت بسيار زياد شده.

كفتم: در قصه اش مباش داكتر ها خو كم نيست. صبح بخير يك تصديق جور كرده به مكتب مياورم. او گفت:در اين صورت جيزى گفنته نمينوانم براى شما جى مشكل است. همين را كَفت و رفت. من با دوستانم مشوره

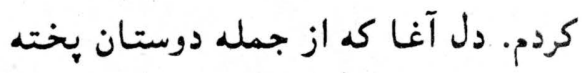
ما بود گفت: بيغم باش بادار، تصديقت

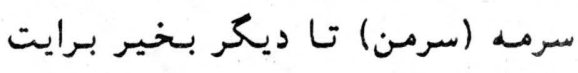

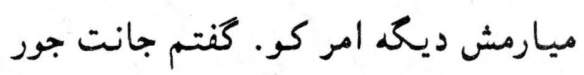
زنده خوباشي، فقط يك تصديق كار است است كيت

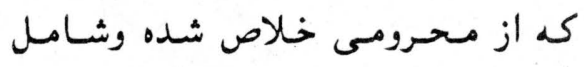

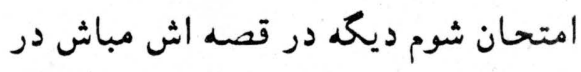




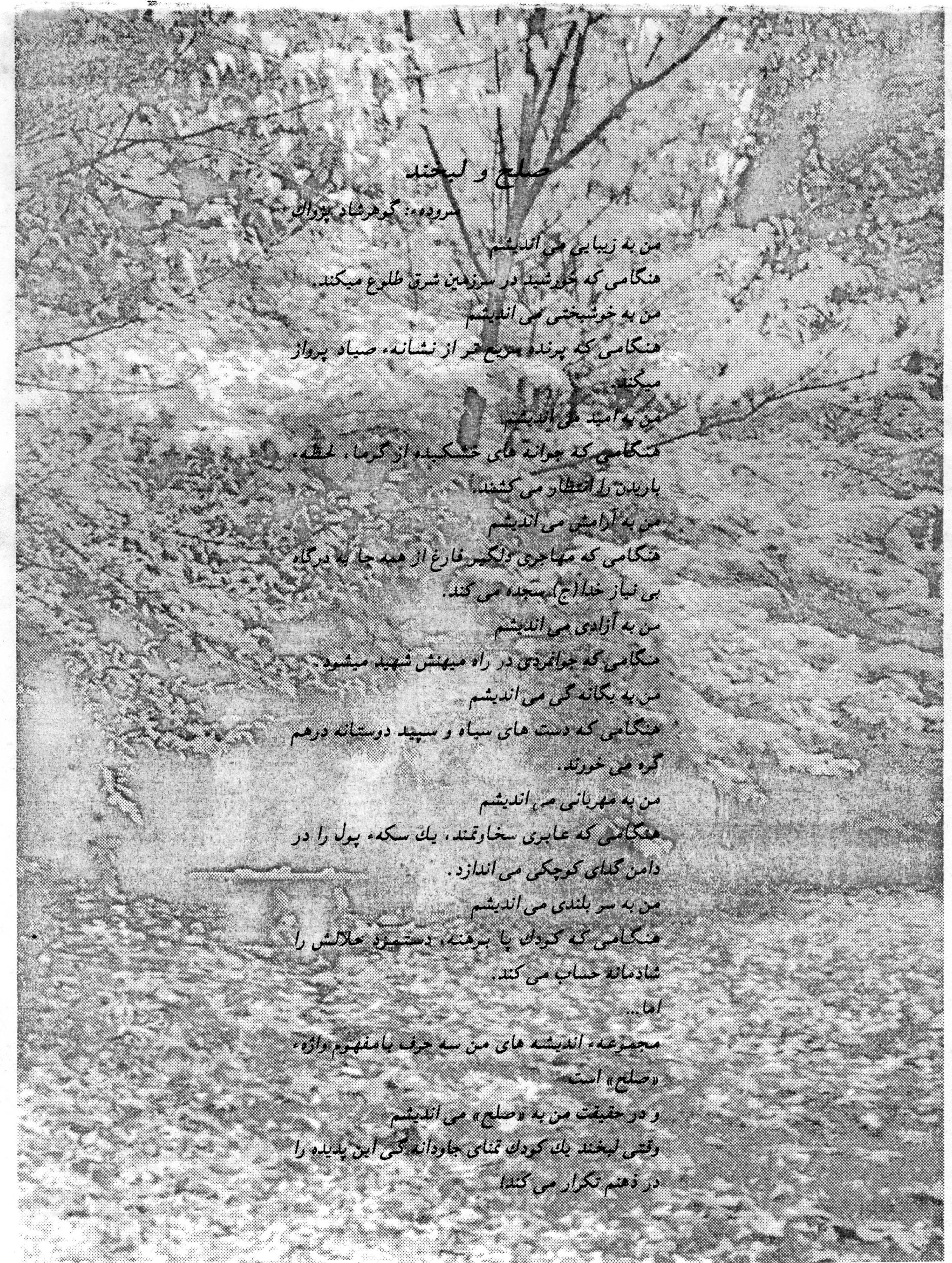


رنكين كمان

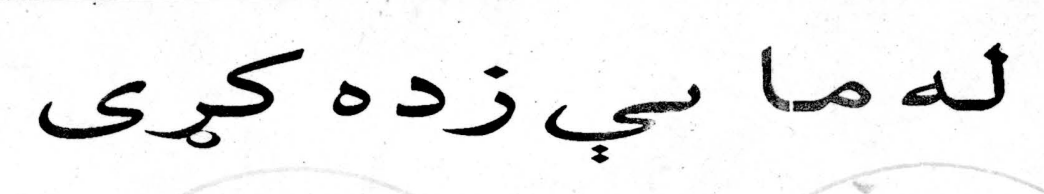

سهار بحى له خوبه جكيبرم تولوته سلامكوم.
بيا نو آرامه بيده كيرم.
دشبى للخوبه مخكى خنل غانبونه يه برس ياكوم.
ديلار، مور اونورومشرانو خبروته غور. نيسم.
جى دسهار جاى مى وخبنه بيا بنوونتئ ته ئم.
سيورت هم كوم.

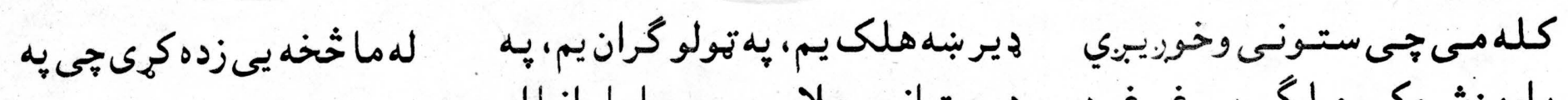
تولخرانواوسى.

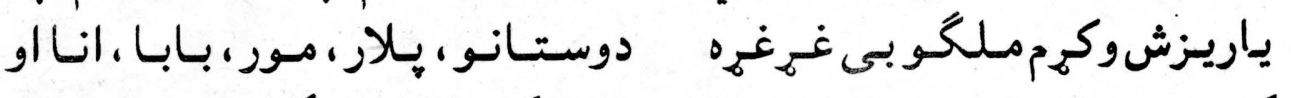
بنوونكى باندى هم كرانيم. كوم. 


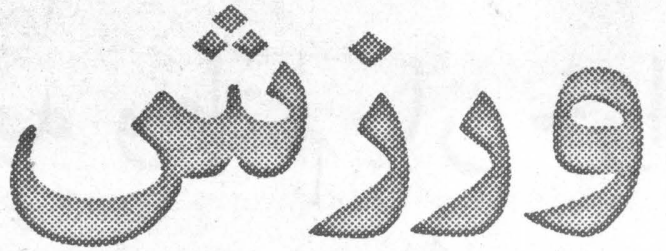

ارسالى: محمد منصور "حسينى"

\section{دور ili}

مسابقات بايسكل سوارى (تور د-فرانس) يا

دور فرانسه عمده ترين و با ارزش ترين تورنمنت بايسكل سواري جهان ميباشد كه هر سال در كشور فرانسه و كشور هاي همجوار آن بركذار ميشود. هشتادوينجمين دور اين مسابقات كه مسافت تمامى آن . . P كيلومتر بود، از شهر باريس آغاز شده و بايسكل سواران جهان اين مسير را كه شامل كشور فرانسه و برخى از كشور هاى آلمان، اتريش و

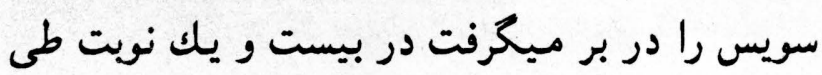
نمودند.

مسافت بيست و يكمين نويت آن را ع ال كيلو متر تشكيل ميداد كه ماركويانتانى از ايتاليا توانست خود را نحست از همه به مسل ختمب مسابقات يعنى شهر باريس برساند و با مجموع

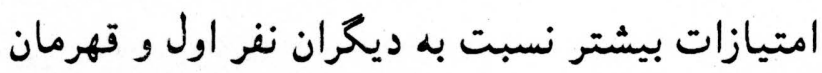
امسال در جهان شناخته شد. يان الريخ از كشور آلمان مدافع قهرمانى با بان

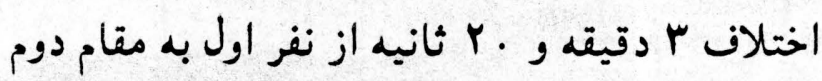

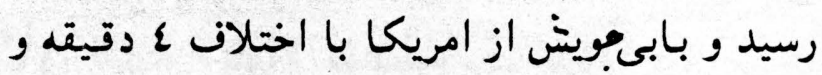
IV ثانيه از بانتى نى حايز مقام سوم كرديد.

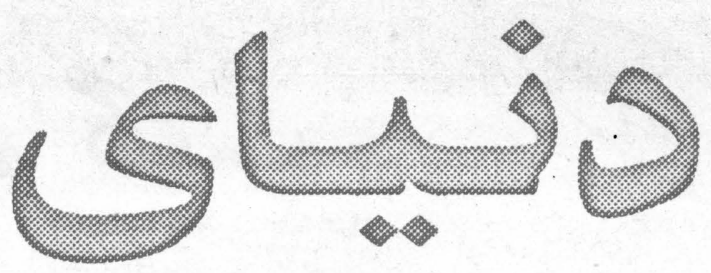

\section{جام تينس آزاد آمريا}

آخرين تورنمنت عمده جهان تينس امسال در شهر نيويارك

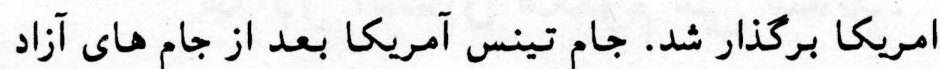

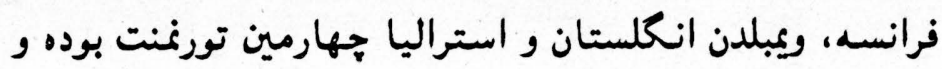

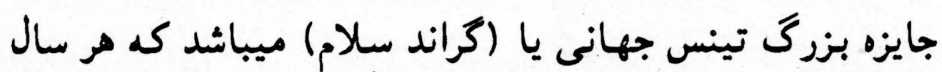

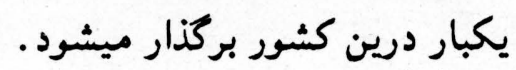

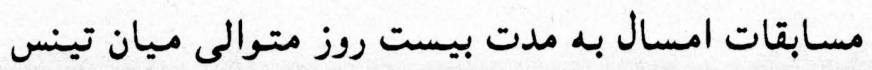

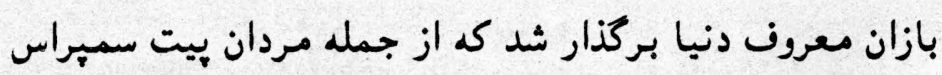

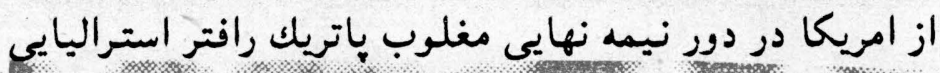

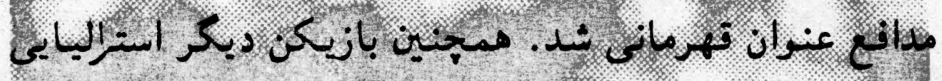

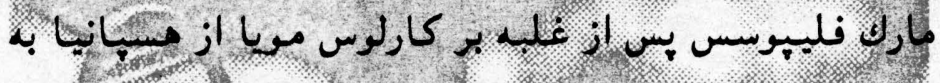

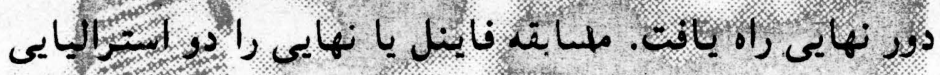

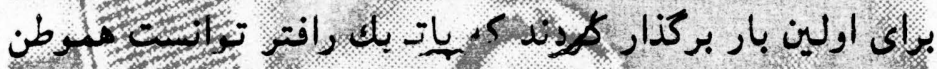

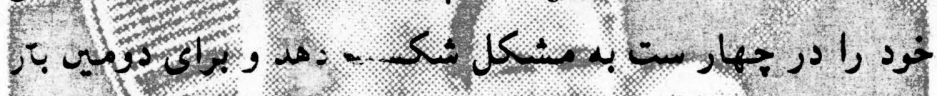

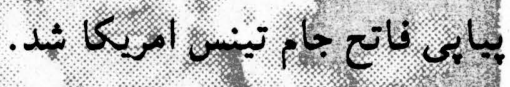

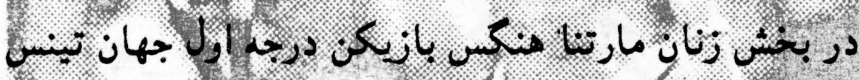

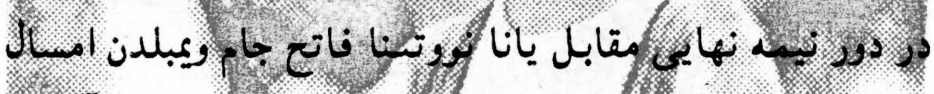

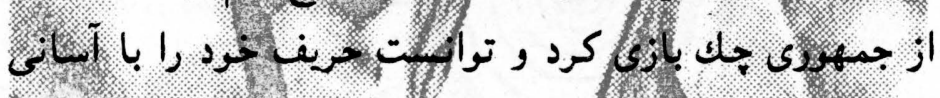

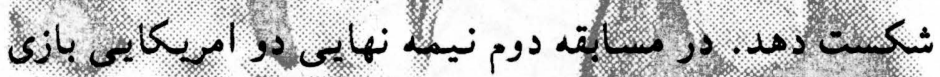

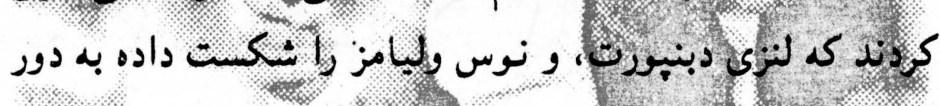
1.

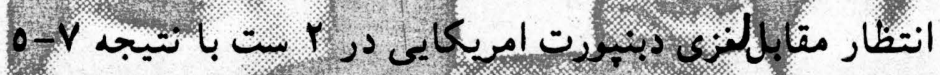
|

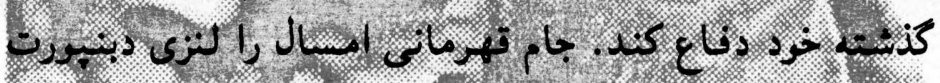

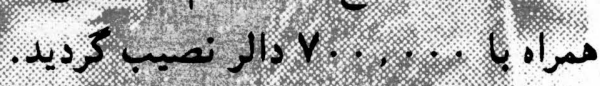




\section{رنكيت}

سال سوم شماره سى وهفتم سنبله ITVV

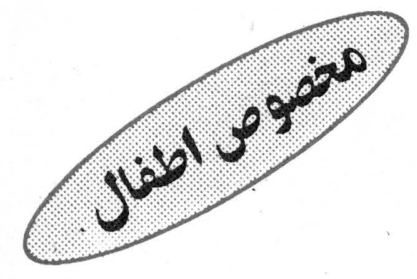

به وطنم باز خواهم كثت

$$
\text { 少旅为 }
$$

ها در آسمان معلوم مى شدند.

$$
\text { شب بود خوابم نمى برد }
$$
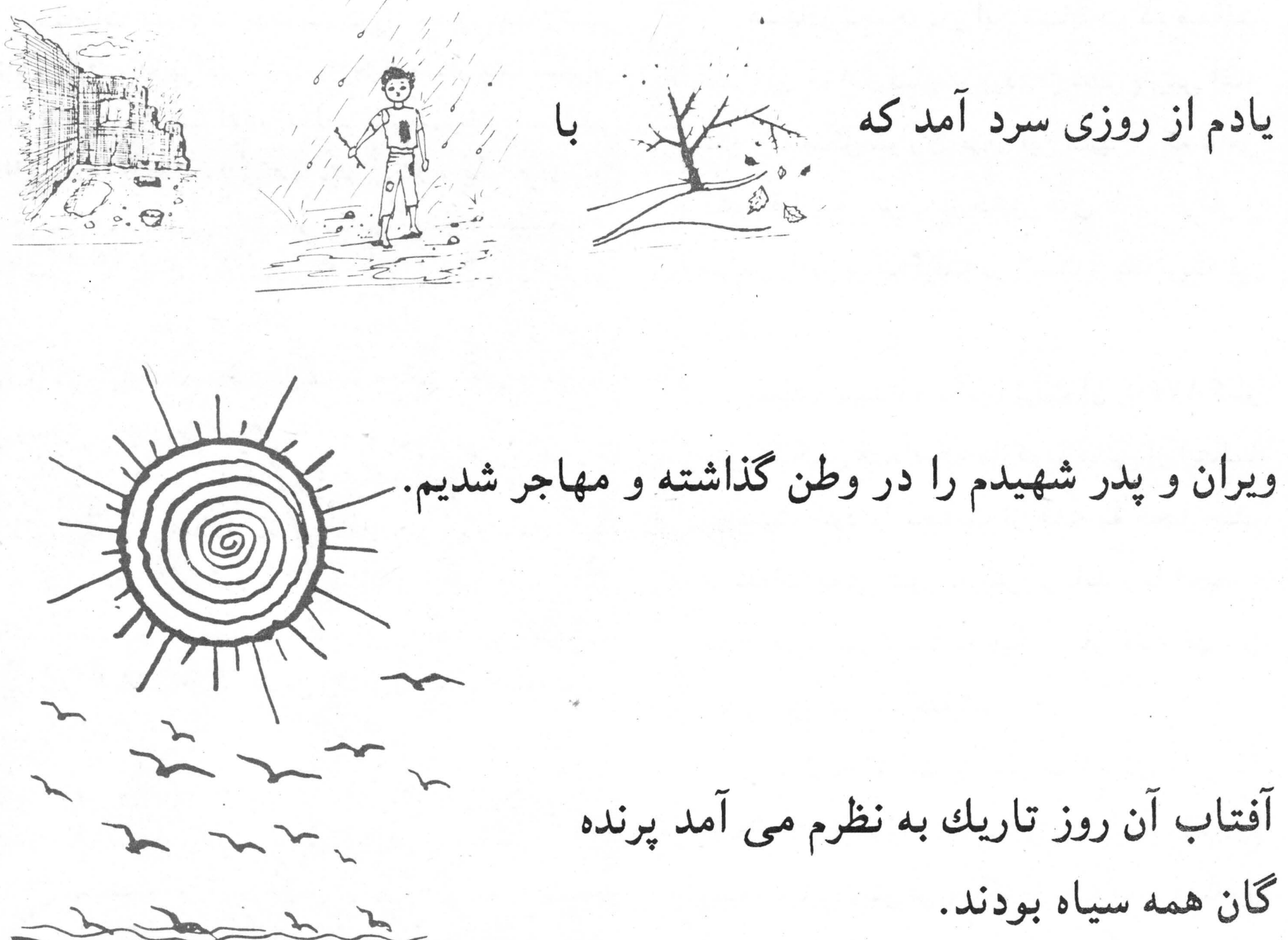
لاله هاى صلح مى رويند.
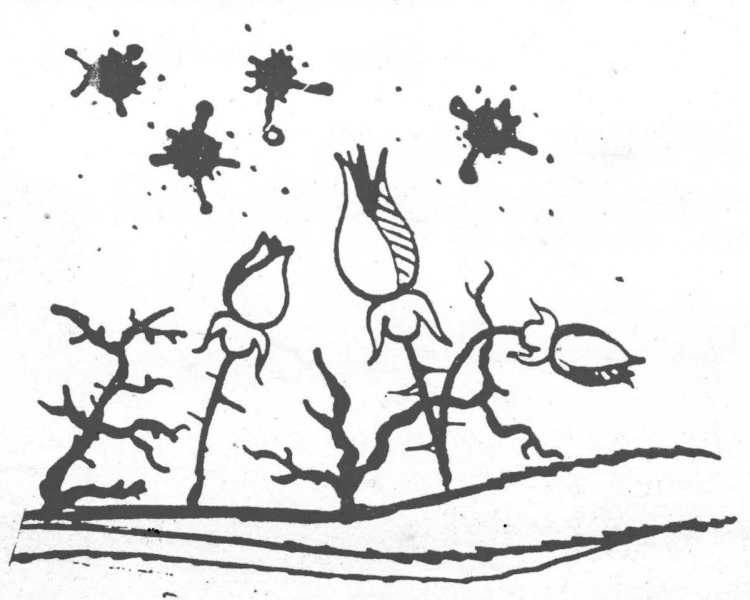

آفتاب باز خواهد درخشيد.

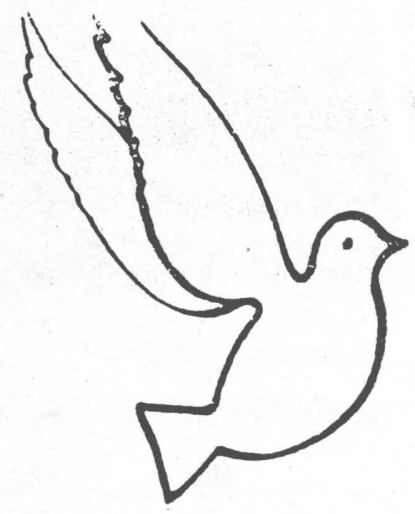

وطن گلزار خواهد شد.
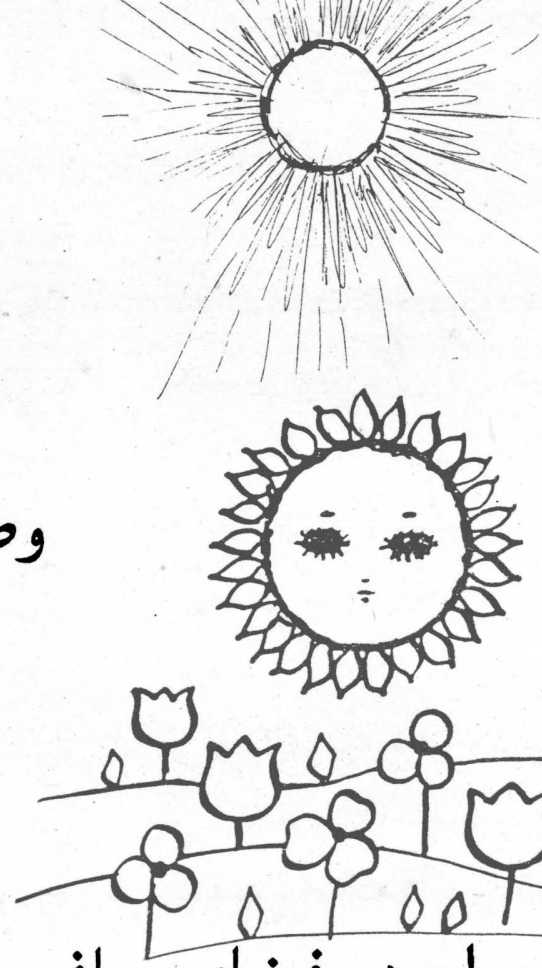


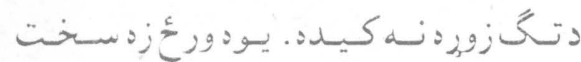

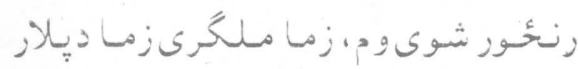

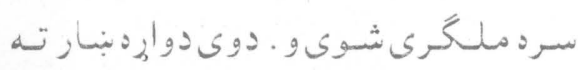

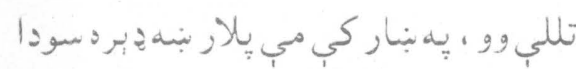

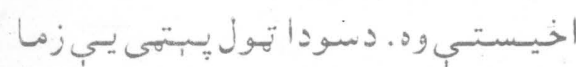

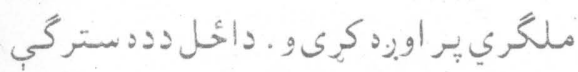

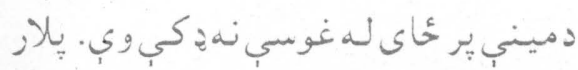
مي دده يه طبيعت نه يوهيدة.

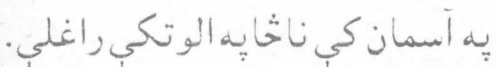

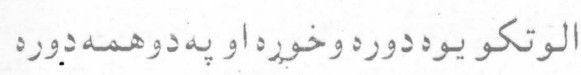

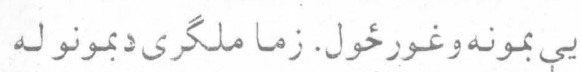

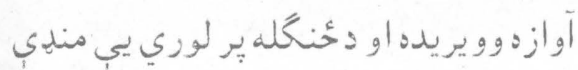

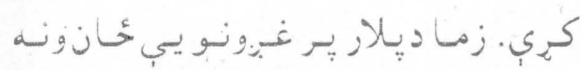

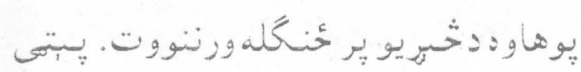

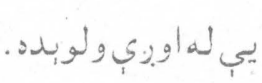

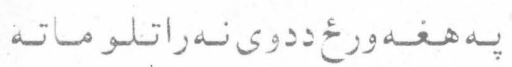

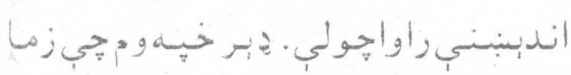

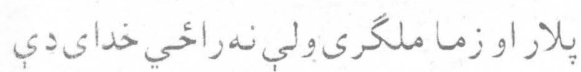

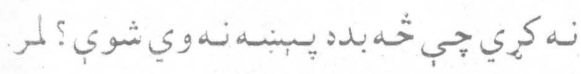

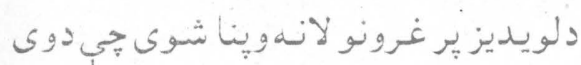

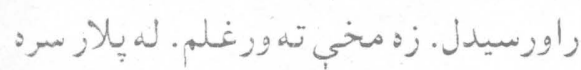

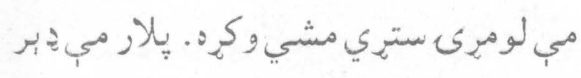

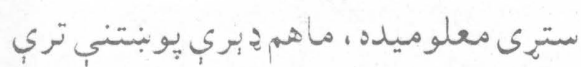

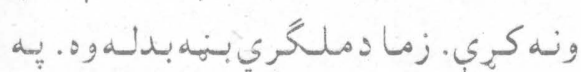

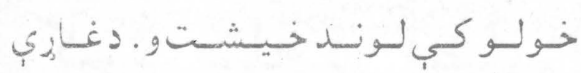

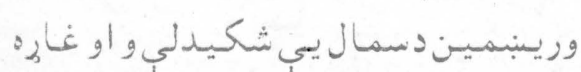

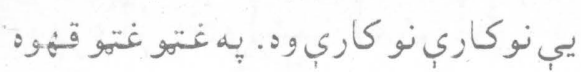

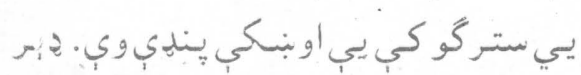

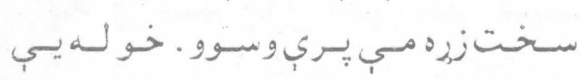
راوز اندي كردخو مـا دخلكو له شرمهنبيكل نمكر. " " نور بيا "

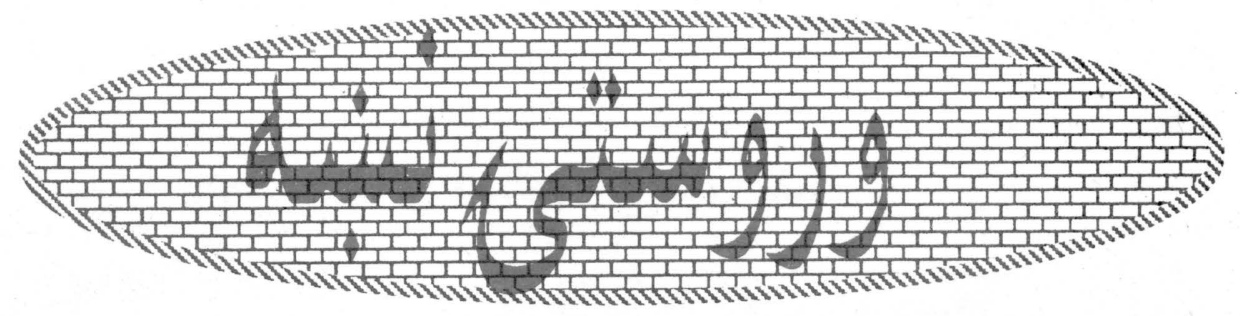

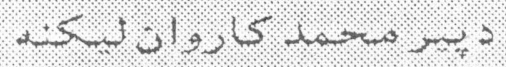

به مي دلويو غرونو ننداره كوله. هغـه لري

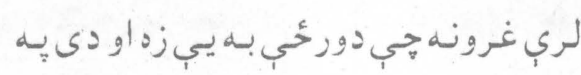

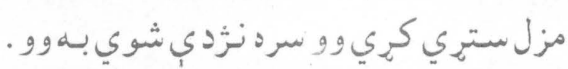

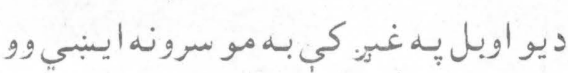
او له يو بل سره ببه مو مينه كوله.

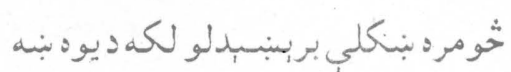

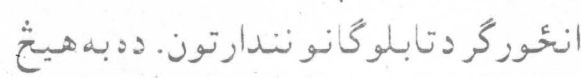

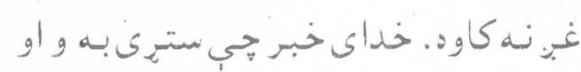

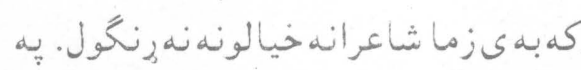

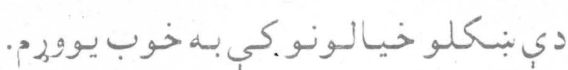

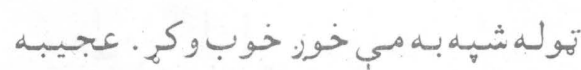

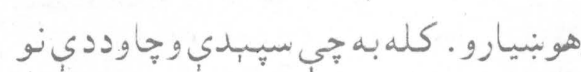

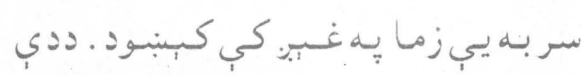

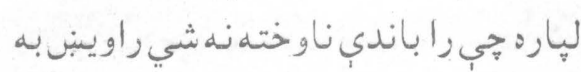

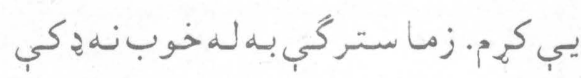

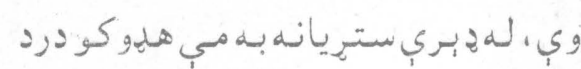

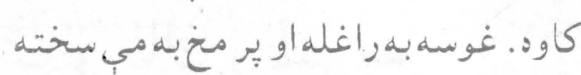

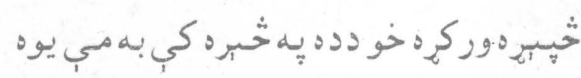

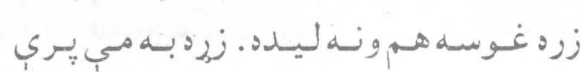

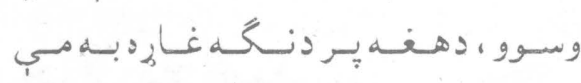

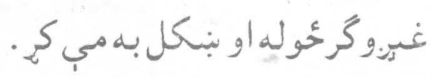

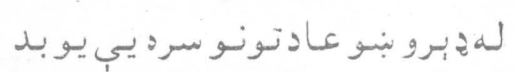

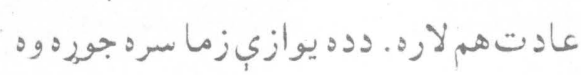

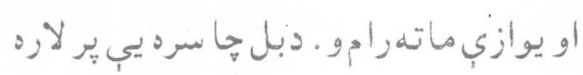

جير راتهُكرانو. ملكُرى جاتهنهوى

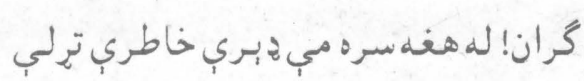
وي. زه بر هغهنبيخي مين شوى و م. خوهره

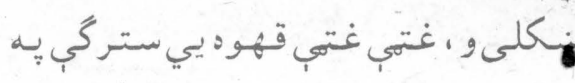

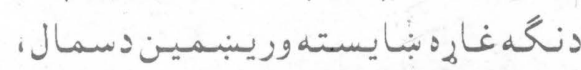

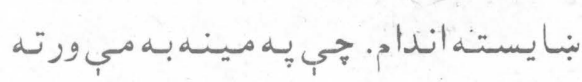

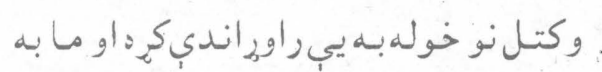

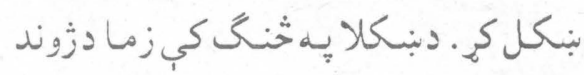

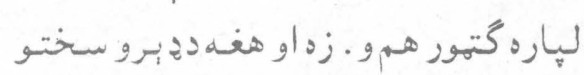

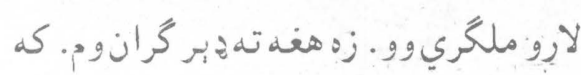

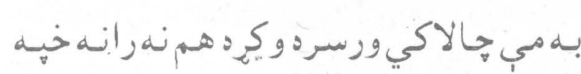

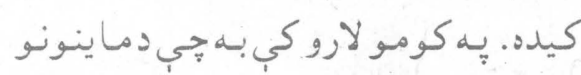

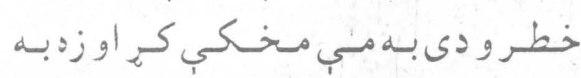

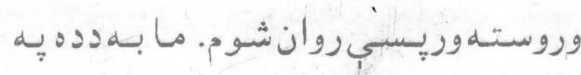

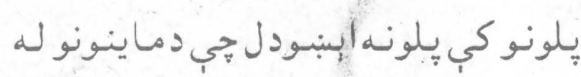
خطرنه وزغورلشم.

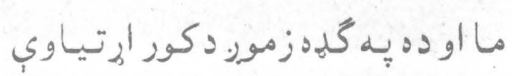

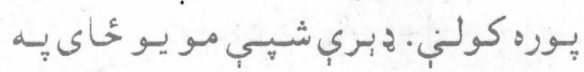

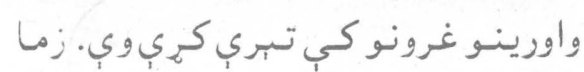

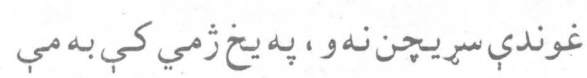

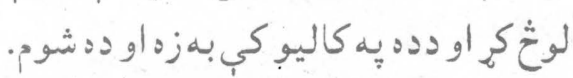

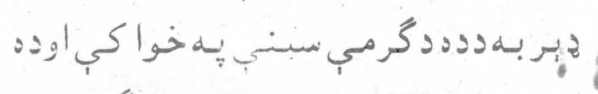

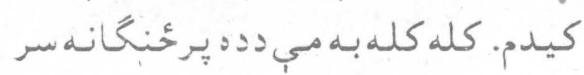

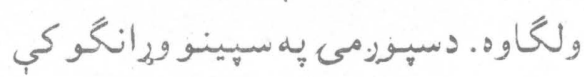


I IVVV سال سوم شماره سي وهفتم سنبله

(4) (1)

Ir Ir II I. A A V Y 0 \& $r$ r I

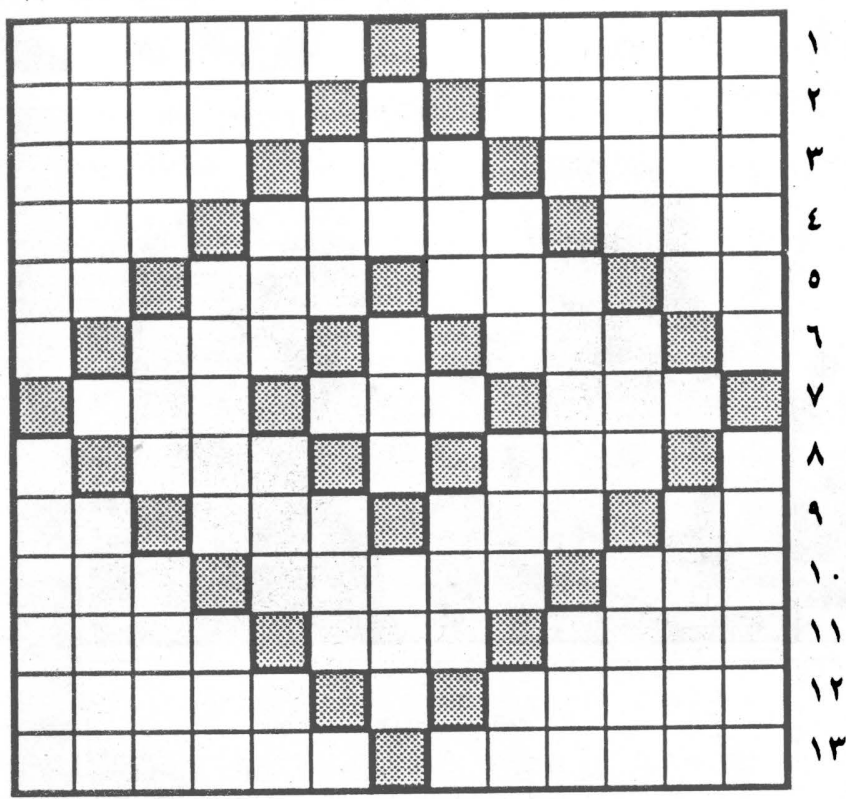

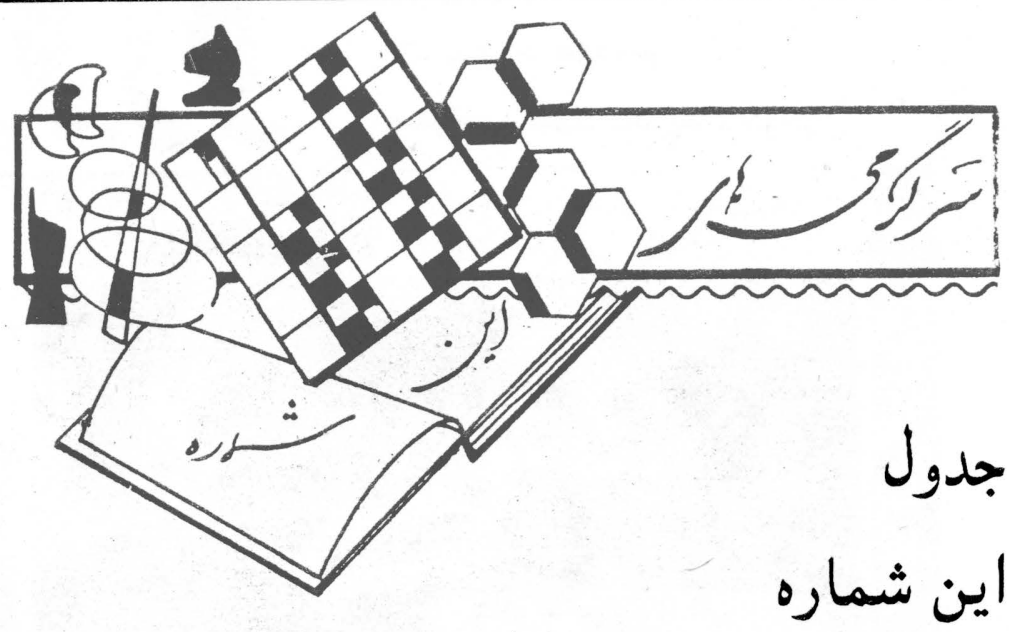

مرتب: عاليه مستتور شنـوارى

ه- بديع - جشم از جهان بست - كوسنند ماده

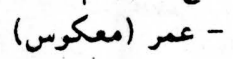

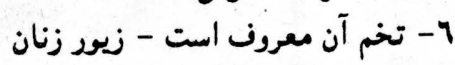

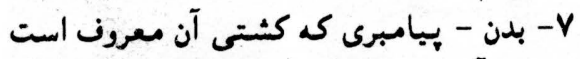

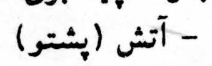

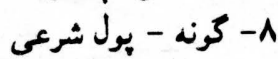
4- استفراع اطفال - عذاب - عزل - واحد آن نبوتن

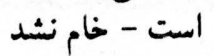

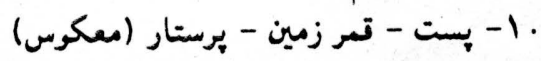

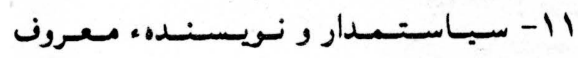

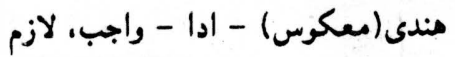

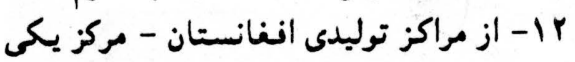

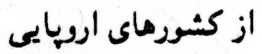

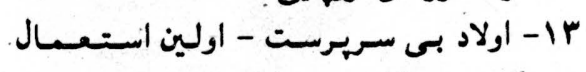
كنتدهء بم اتمى در جهان يستر
11- به تكرار (معكوس) - به هر شكل در ميآيد - شمارش

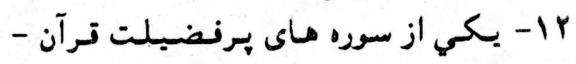
خروس كوخك

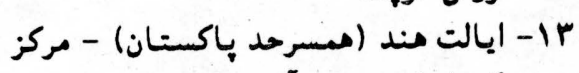
يكى از كثررهاى آسيايى

عمودى: 1- يكمى از بندماى برق در انغانستـان - نام تديم اطريش

r

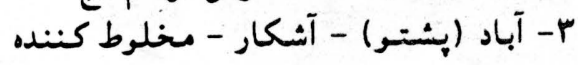

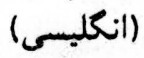
ع- مخفن امبر (معكوس) - بنيانكزار بكى (أسى از سبكهاى نقاشى - مرده (عريى)
1 - طويلترين سرحد انفانستان - اسكندر بآن معرون است r- اختراع ماركونى - بلندترين تله - جهان

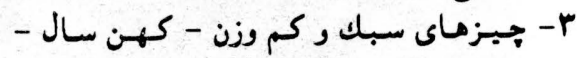
نهايت بع بايان ع- نياز اول بشر - هوشيده، رمزدار - ستاره

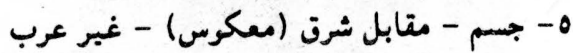
- از حروف الفبا 1- يكى از بادشاهان عربى - كرو ، ترض

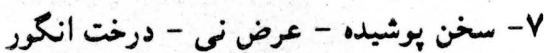

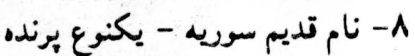

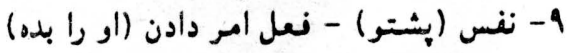

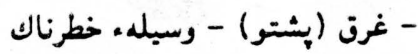

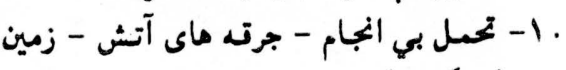
(معكوس)
- هيست آن لعبت بسنديده، جامعه سرخ و سبز يوشيده. در ميان دوخانه سنكين، به له هزار و دو حيله كنجيده. دولت الله نذير صنف نهم ليسه شاه دوشمشيره (ع)

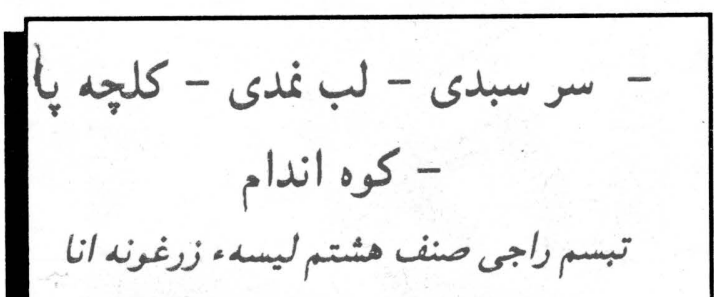
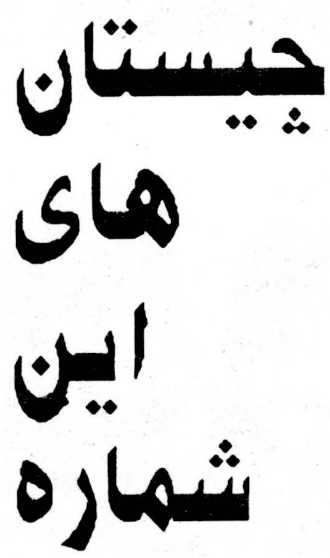

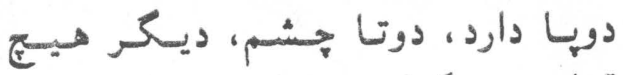

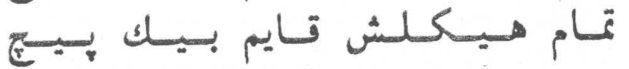

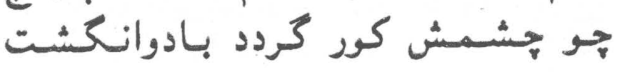

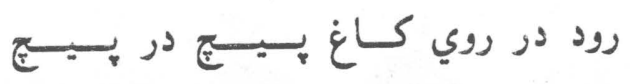

- آن جيست كل به هـ لمان بنوانى اش، غلط است. مينا متعلم ليسه عبدالله بن زيد 

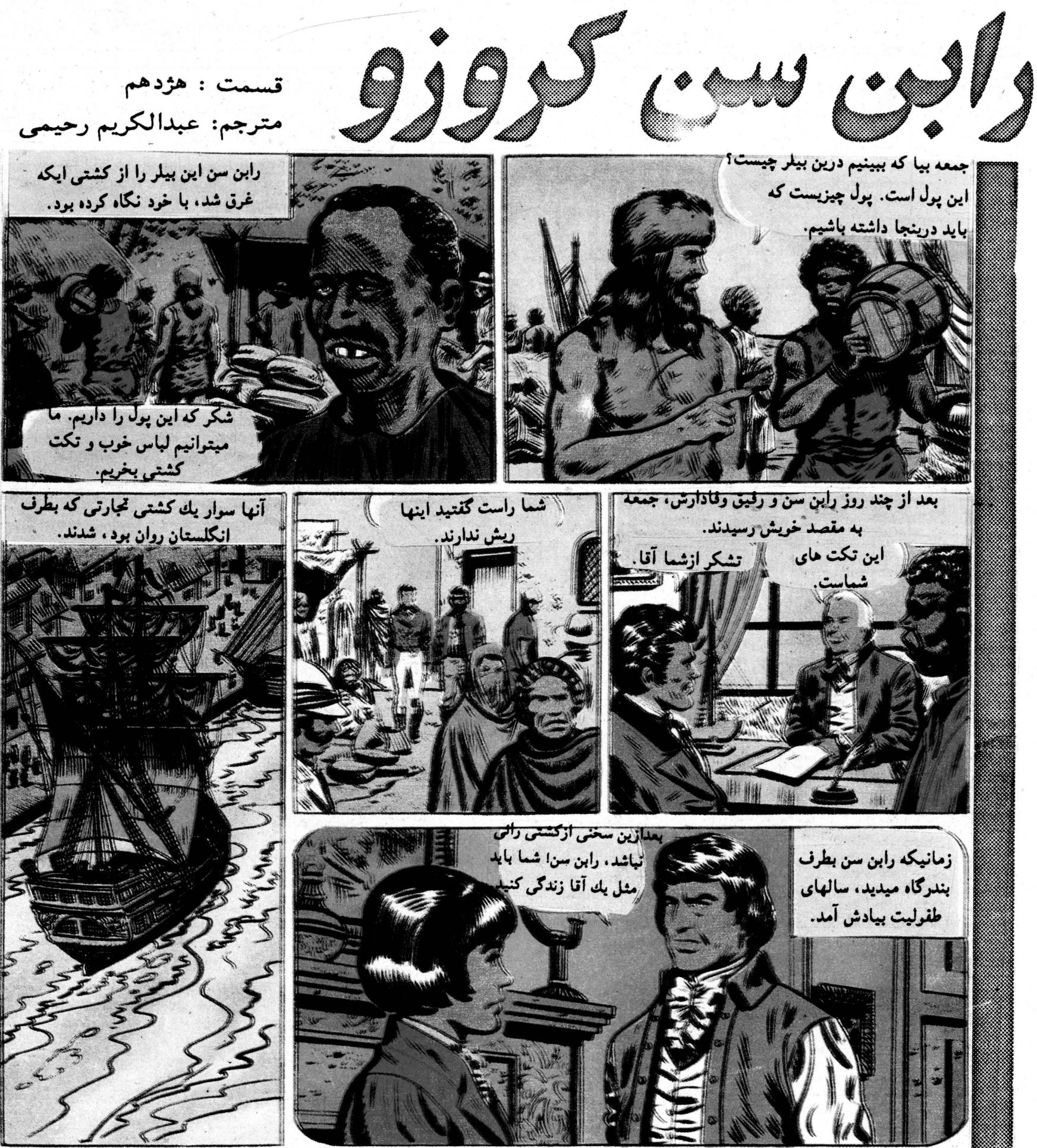

بس ازسالها رابن سن كى را خواهد ديد؟ آيا
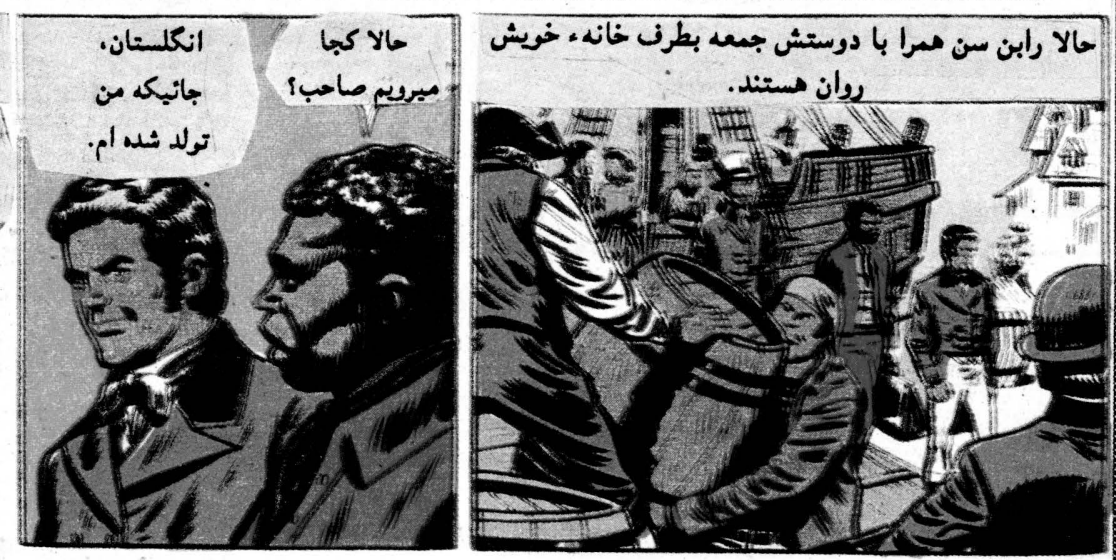

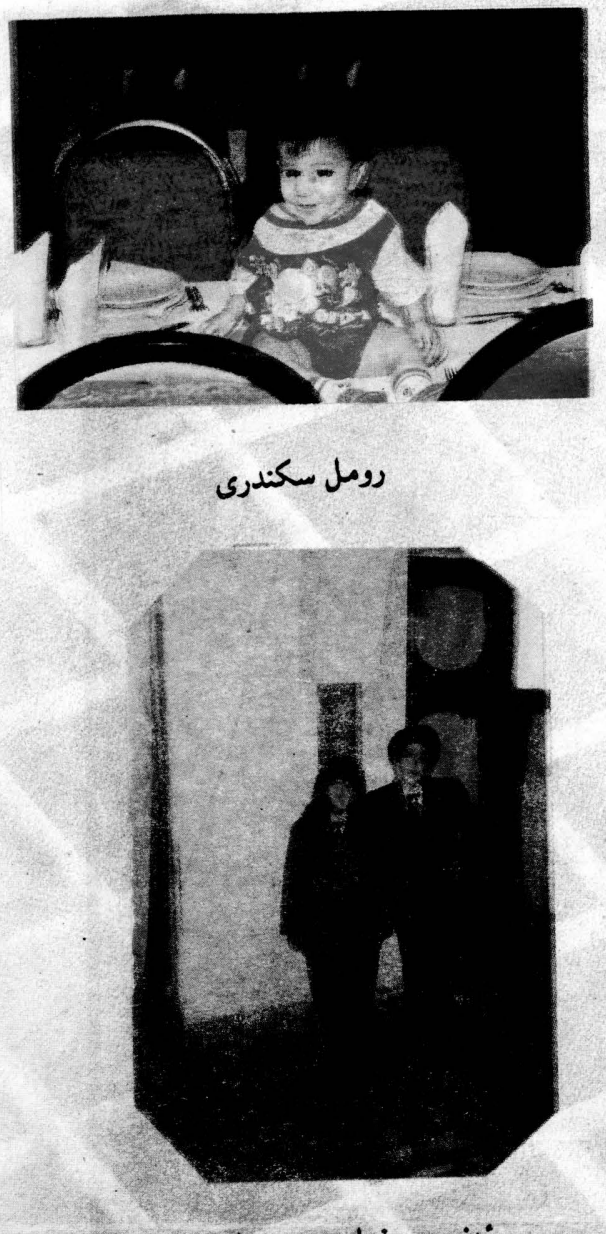

رونين ميريخيل و سونيتا ميريخيل

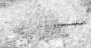

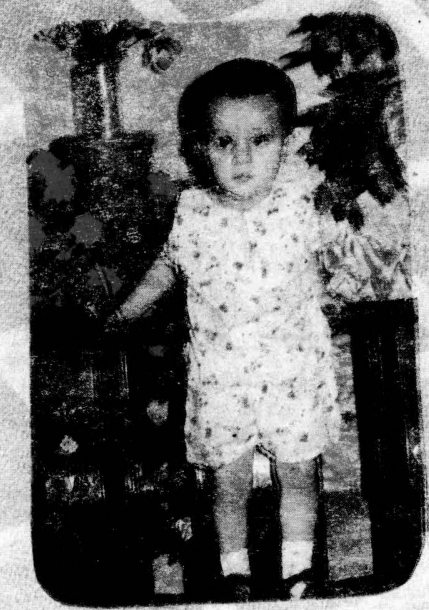

اجمل سكندىى
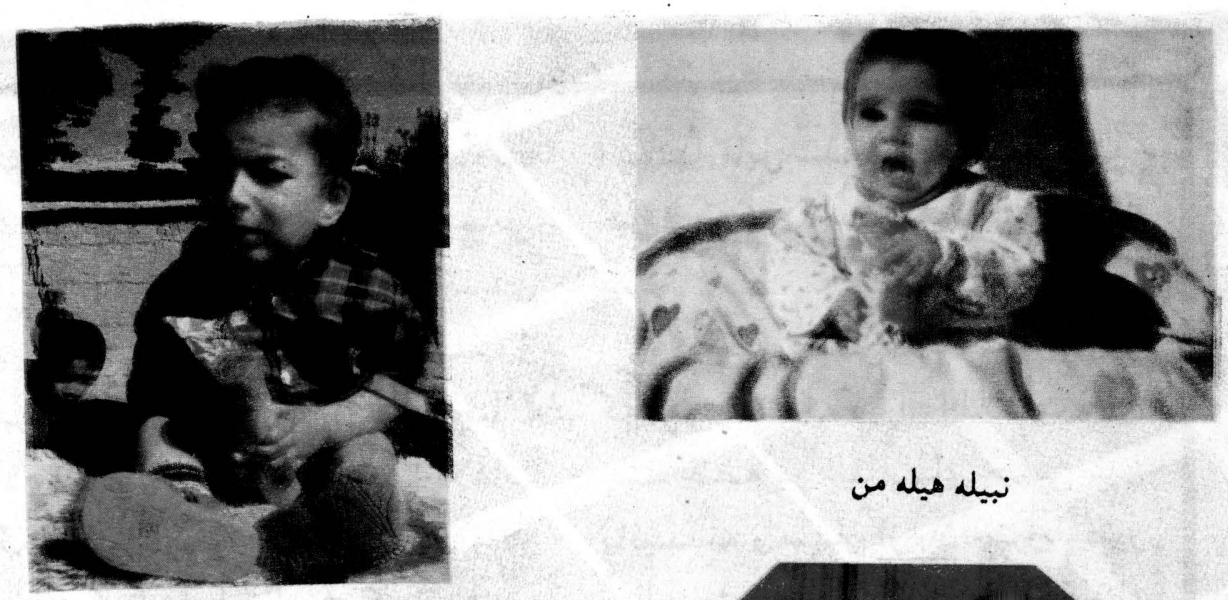

مطيع الله امين زاده.

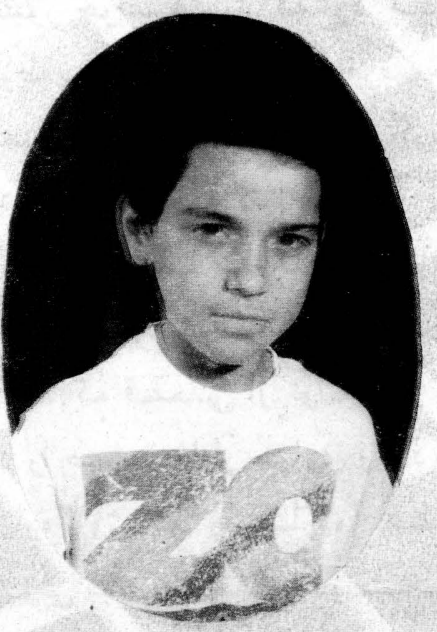

زرهاد جلن
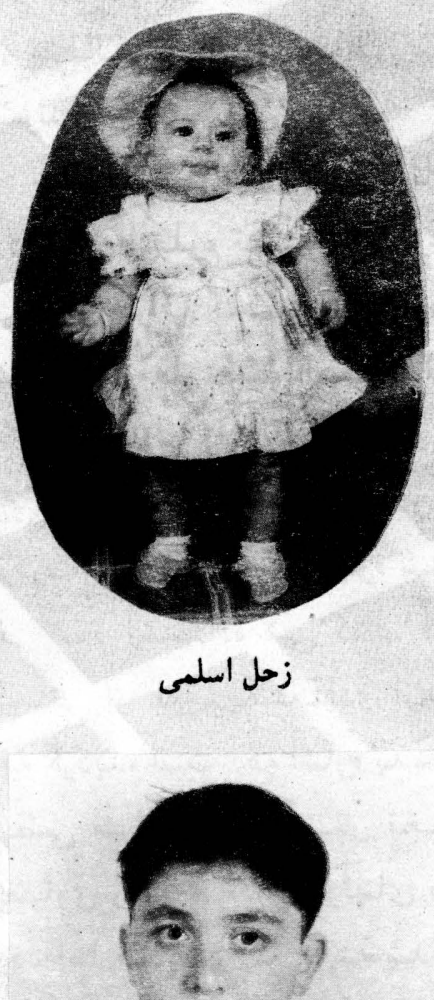

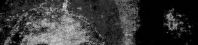

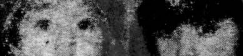

a $4: 5$

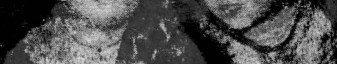

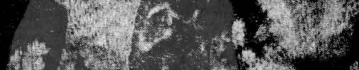

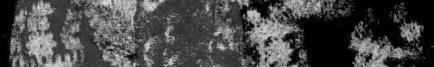

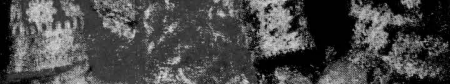


انسبانها قايل شده اند: حافظه، حسى،

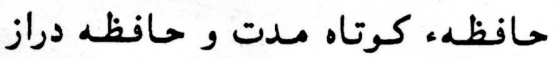

مدت.

حافظه، حسى: حافظه. بسيار كوتاهى است كه در آن اطلاعات براى حئه

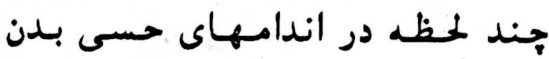
باقيمانده و سبس از بين ميرود بطور مثال: جشم (حس بينايى) داراى حافظه حسى كوتاه مدتى كه مي تواند خاطره

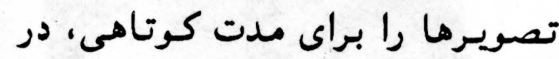

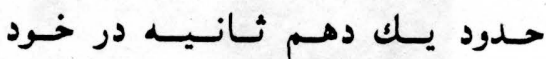
نكهميدارد.

حافظه، كوتاه مدت:حافظه اى است كه اطلاعات را تا زمانى حفظ مى مئ مئ كنند كه شما بآن فكر مى كنيد مثل مثلاً:

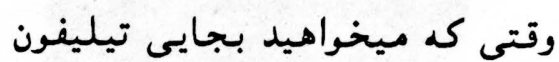

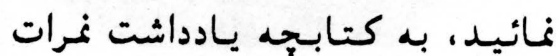
تيليفون مراجعه كرده و شمارهء مورد بائيد

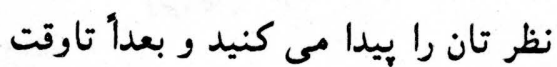

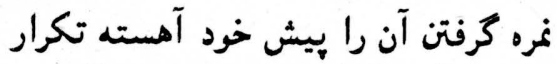

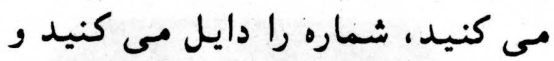
صحبت مينمائيد. اما بعد از آندا دآ ديكر

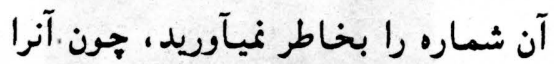

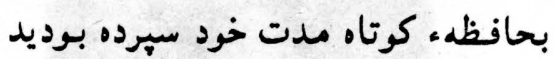
و خصوصيت اين حافظه اينست كه كردي

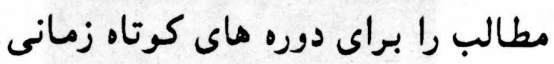
در خود حفظ مى كنند.

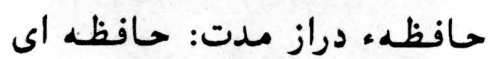
است كه اطلاعات براى وقت بيشتر (جند دقيقه تا سالها) در آن حفظ إنظ

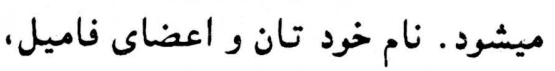

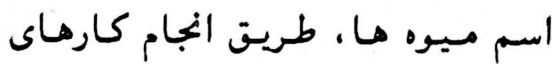
روزانه مثل: برس كردن دئدانها وبسيار

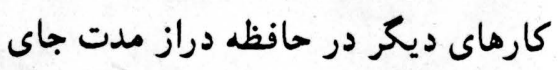

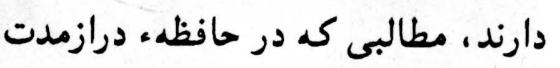

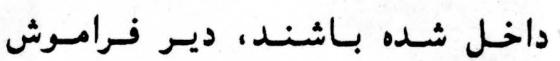

$$
\text { ميشوند. }
$$

مثال: شما قبلاً آموخته ايد كد قلب يك عضو مهم بدن است و جه ساختمانى

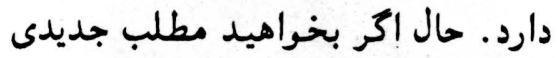

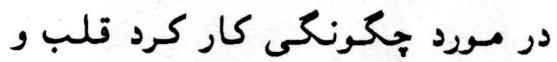

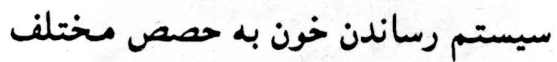
بدن بخاطر بسباريد، اول بايد اطلاعات

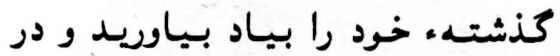

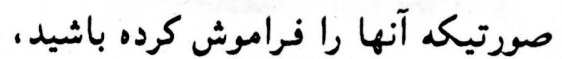
مجببور خواهيد بود كد اولاً مطالب رئب مريوط به ساختمان قلب را مرتبهـ دور وريد

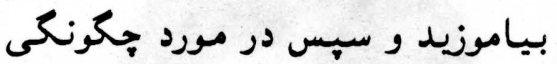
خون رسانى مطالعه كنيد. باين ترتيب مشاهده ميكنيد كه اشخاص نراموشكار هميشه مجبيور

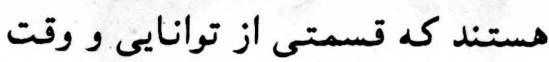
خود را صرف بخاطر سيارى و يادكيرى

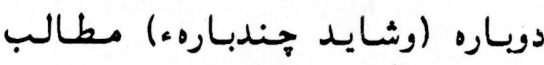

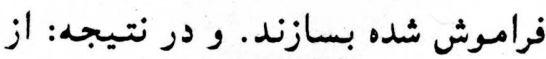

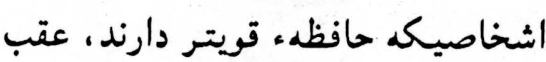
يماند. مطالب جكونه بخاطر سيرده ميشوند: - n متاسفانه جواب اين سوال تا حال به درستى معلوم نشـده است وعلما بدريافت جواب كاملي درين زمينه نرسيده اند. معلوم نشده است كد انسان جكونه مطالب را در مغز خود جمع ندي

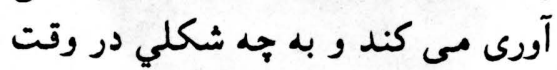

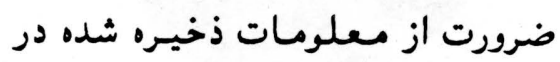

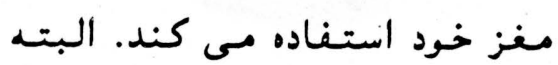
نظرياتى از طرف يكتعدادى از علما ارائه كرديده است. كه اشاره به ساختن بعضى مواد و يبيدا شـدن تغيرديرات

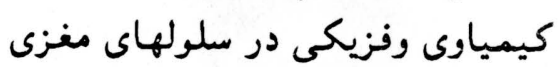

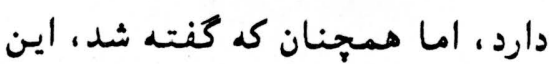
نظريه به تائيد كامل نرسيده است.

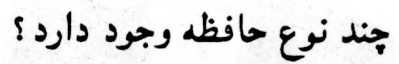
علماء سه نوع حافظه را براى دارد

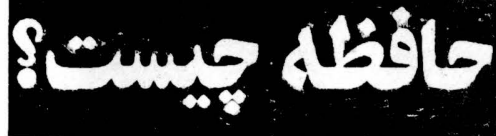

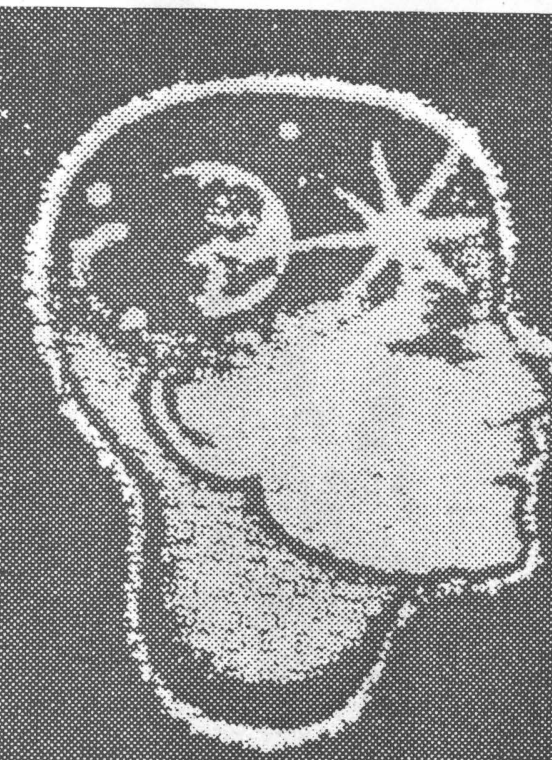


توسط اين ماشين تهيه ميشد به كمك روشى بنام "روش

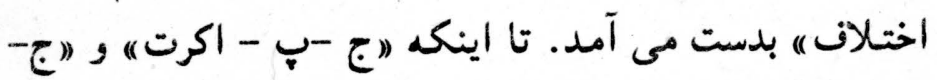

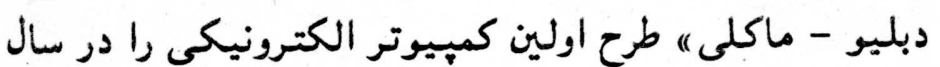

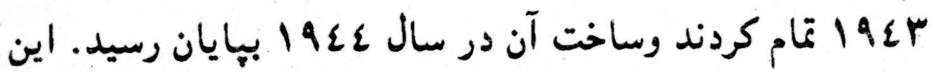

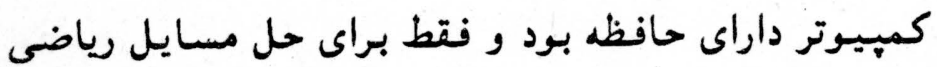

$$
\text { خبر مي رفت. }
$$

جندى قبل اين خبر دنيا را حيران ساخت كد با آمدن سال

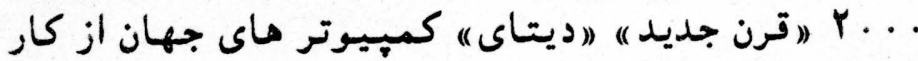

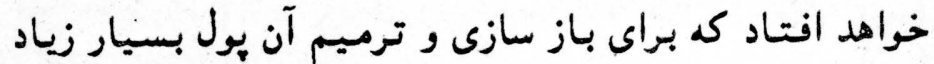

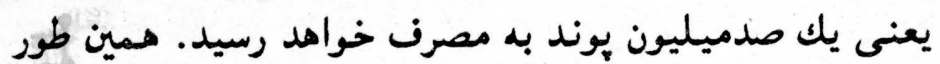

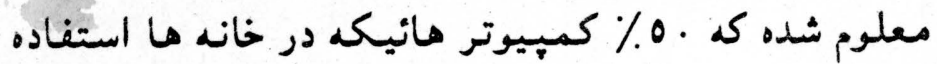

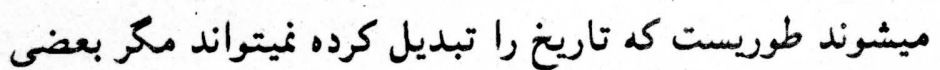

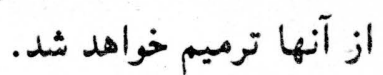
هيروكرام هاى اكثر كميبيوتر ها طوريست كه در آخر سال

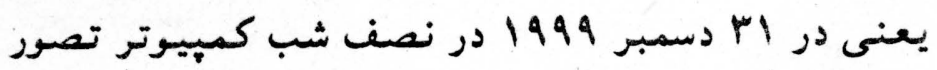

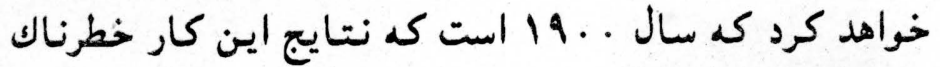

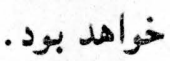
ساينس دانان انكليسى توانسته اند براى حل اين مشكل

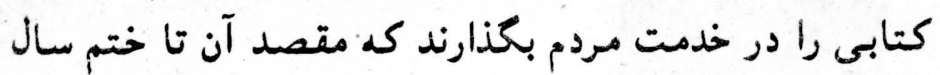

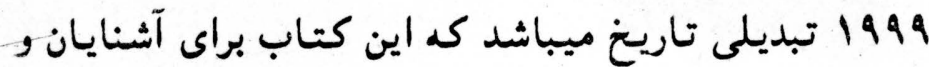

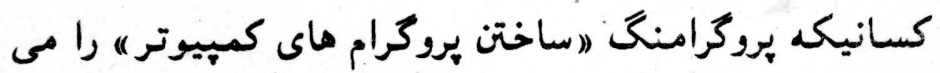

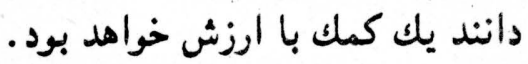

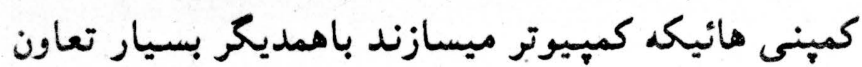
و كمك مى نمايند كه اكر اين مشكل حل نشود خطرناك ثابت منابت

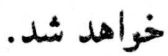
اين كتاب در 1 جلد ميباشد كه توسط آن خواهند توانست از خرابى كمبيوتر جلوگيرى شود و همجنان تاريخ را تبديل

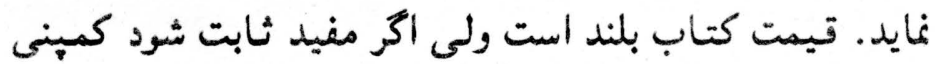

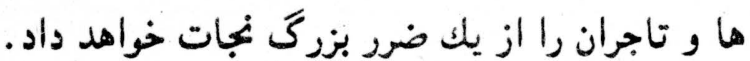
ارسالى سيد محمدعارف وثيق
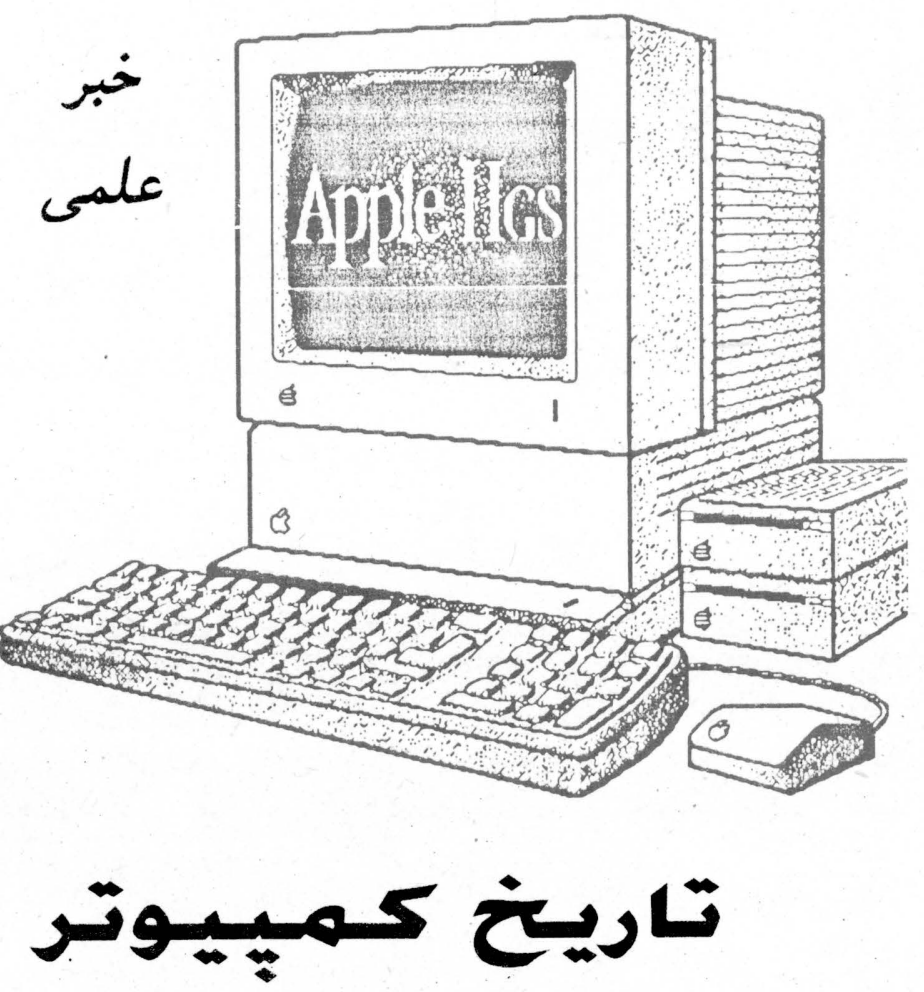

از قرن ها ييش انسان در بي يافتن و سيله اي بوده است كه او را در محاسبه كمك نمايد تا تاني از تلف شدن وقتت جلوخيرى كند مثيلاً:

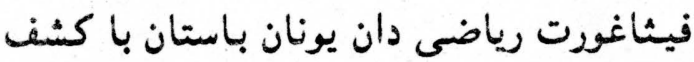
و تنظيم جدول ضرب افقى و عمـودى، كار محاسبه اعداد بزرگتر را فراهم ساخت.

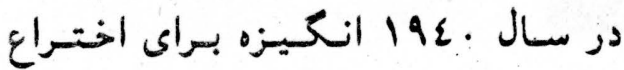

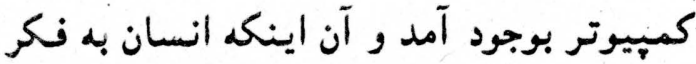
ساختن وسيله اي افتـاد كه علاوه بر ماشين حساب و سرعت محاسبه بتواند عمليات منطقى را هم انجام دهد. ياسكال در سال عـ 14 أولين ماشين جمع كننده ميـخانيكى را در دنيا بوجود آورد. در

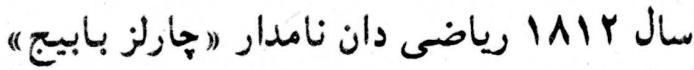
شروع به ساختن يك ماشين ميخانيكى كرد كد

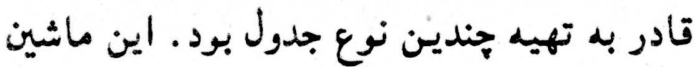

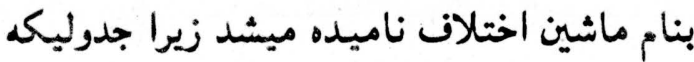




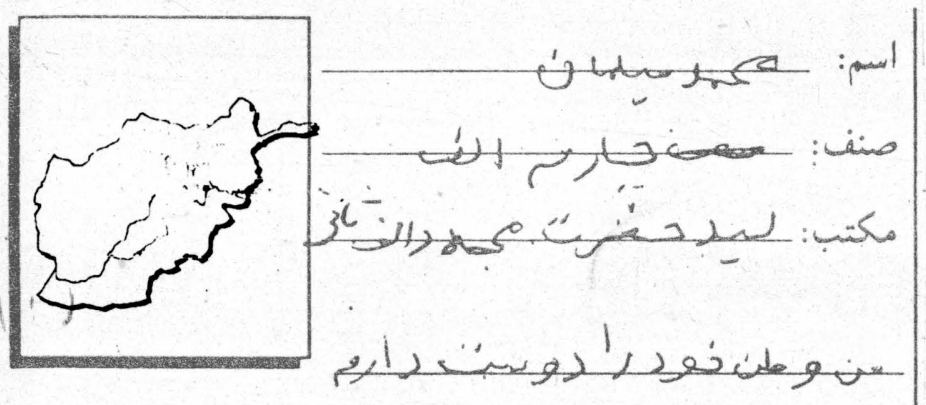

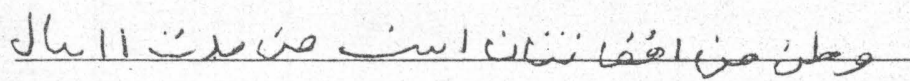

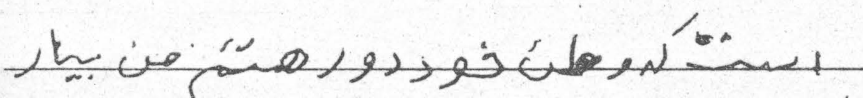

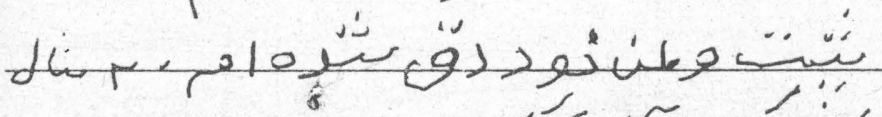

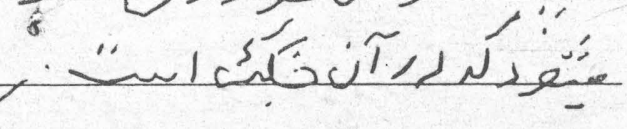

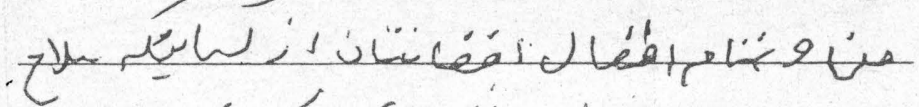

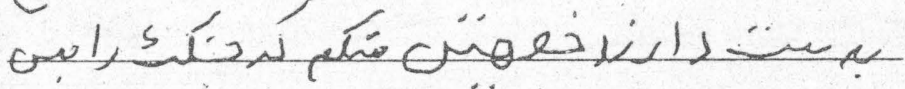

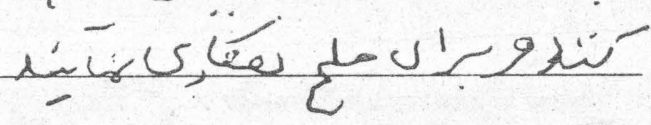
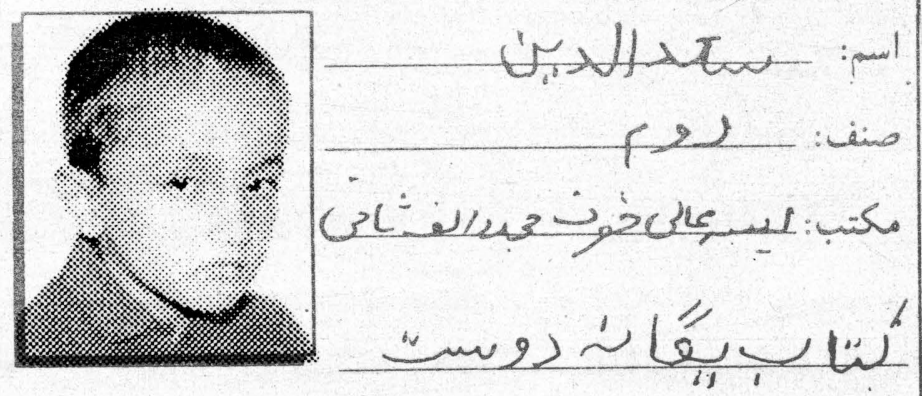

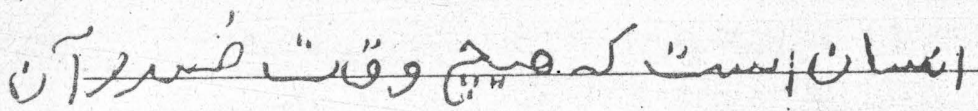
o)

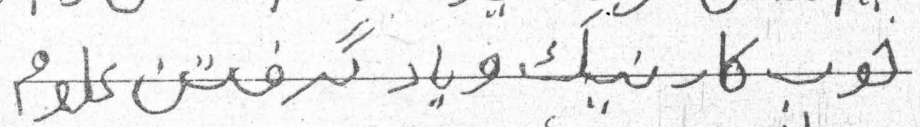

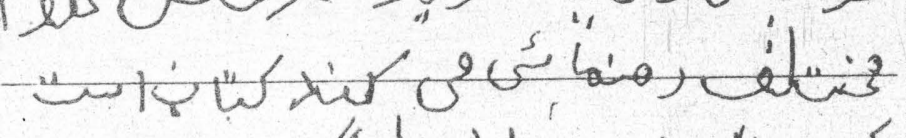

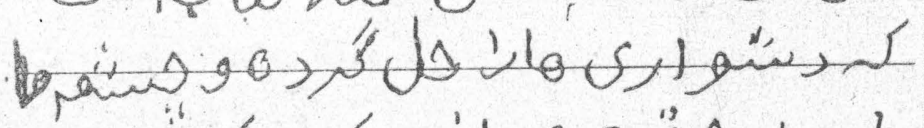

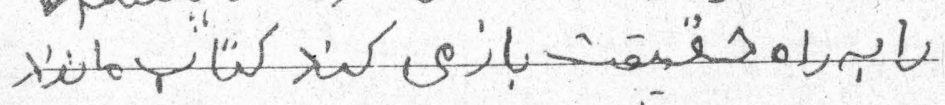

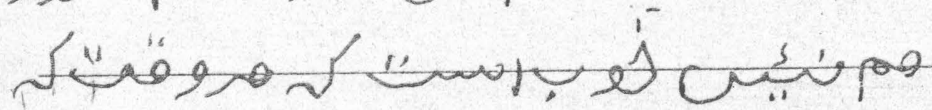

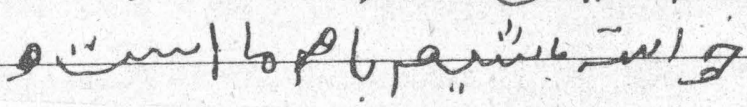

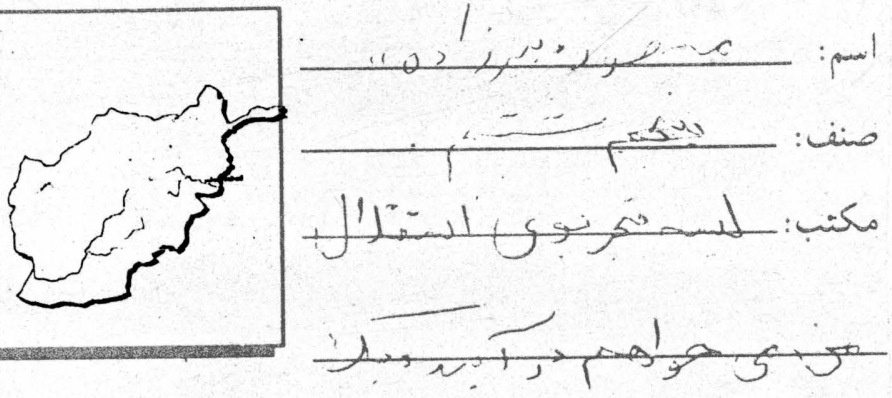

$(j, 1), t_{g}, \sqrt{t}[, \ldots, g, 1) \cdot i=1$

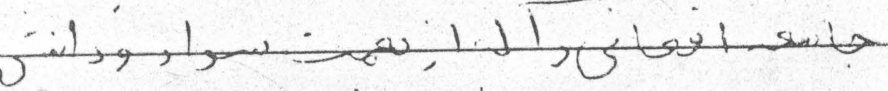

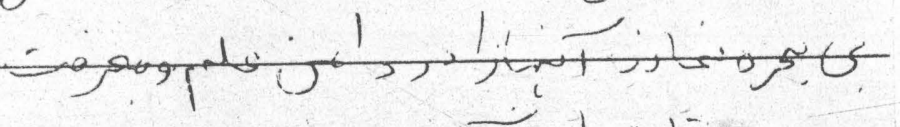

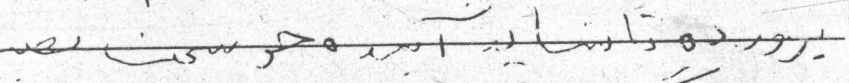

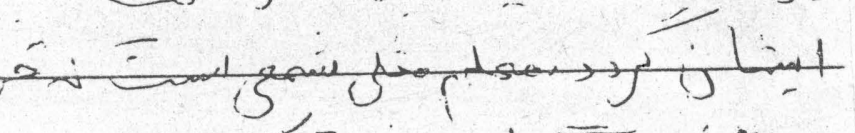
r.

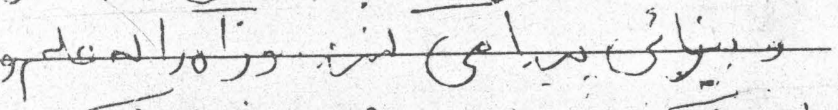
ग)

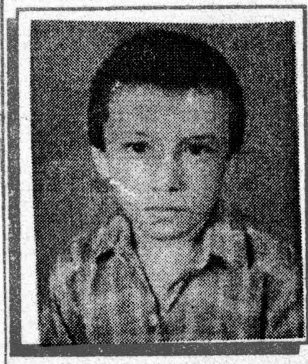

a) iथ/ صنف: مكتب:

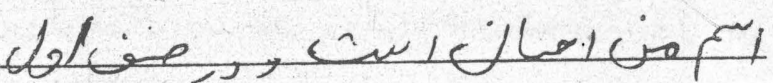

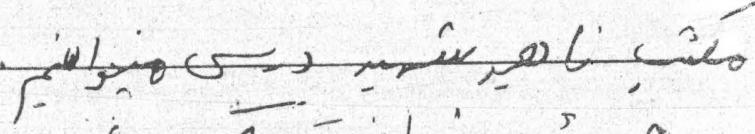

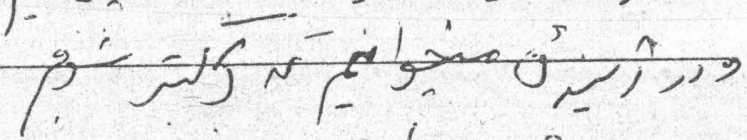

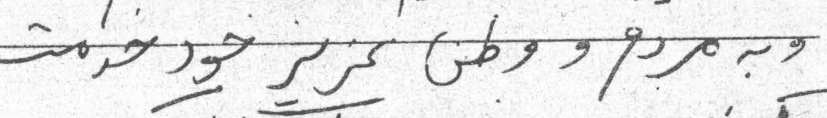
N rint,

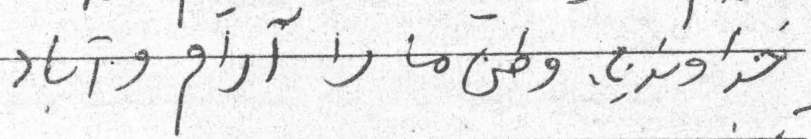




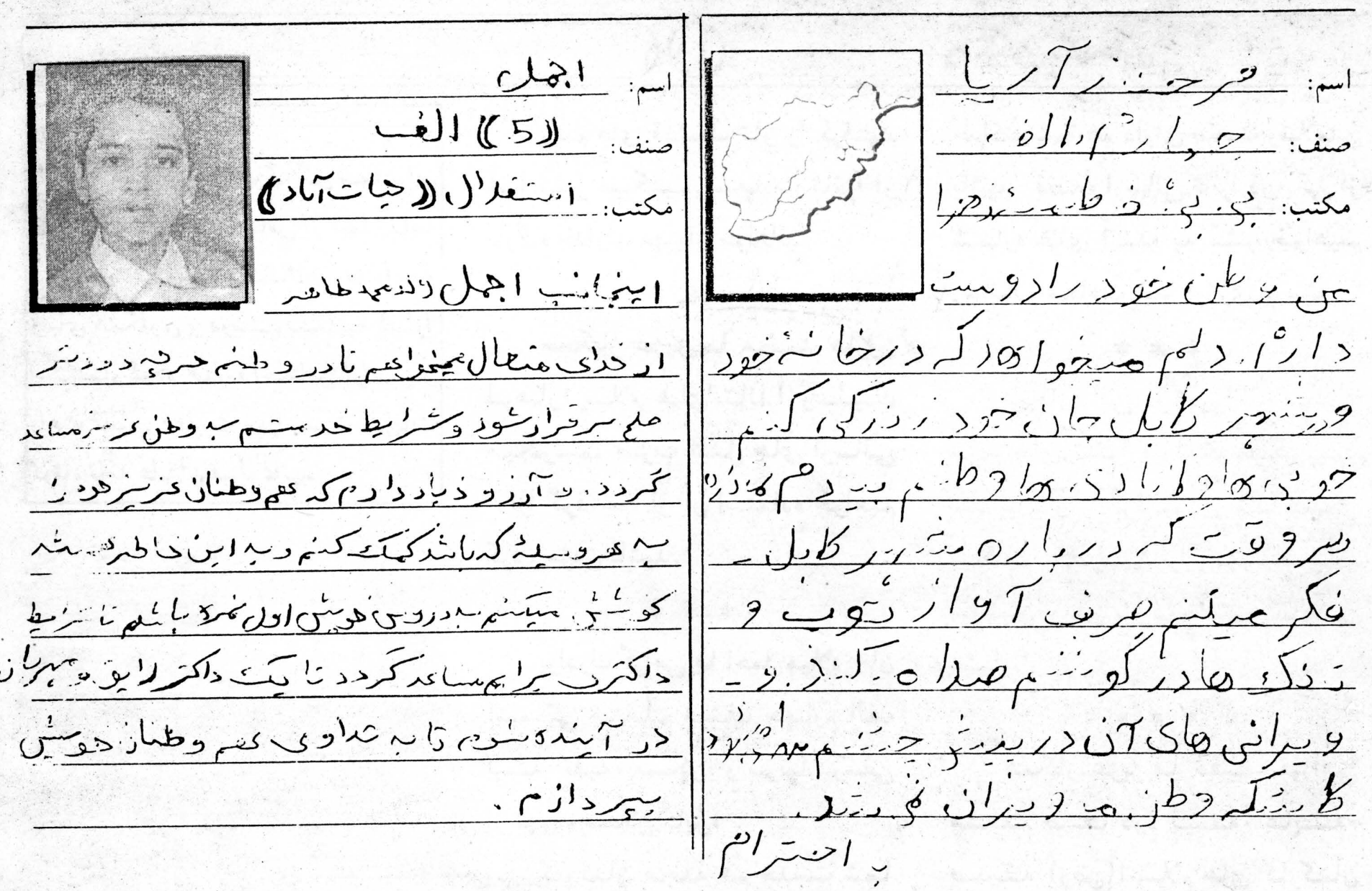

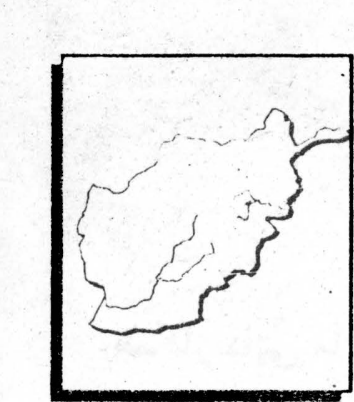

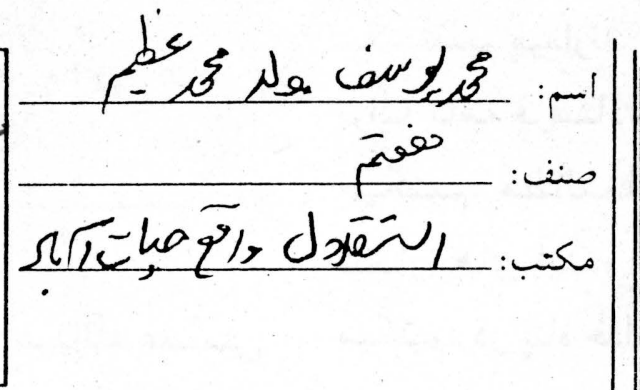

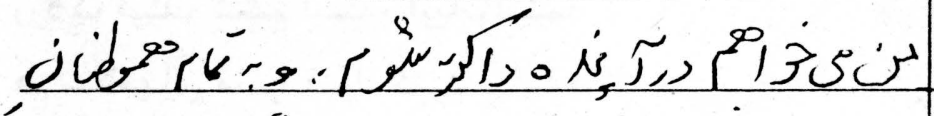

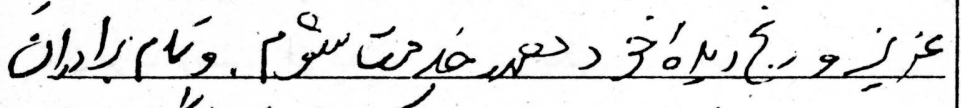
定

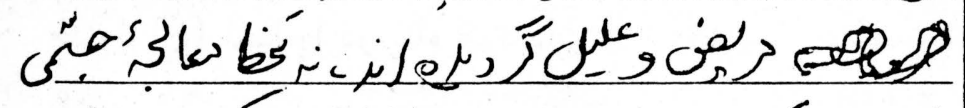

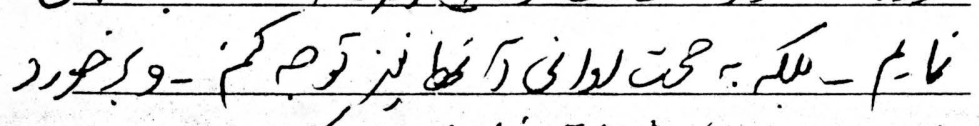

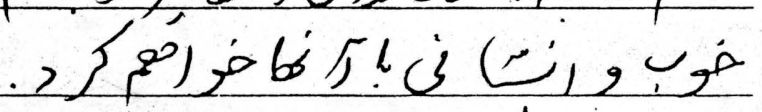

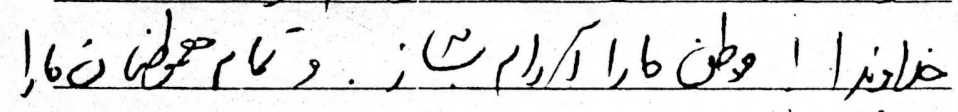

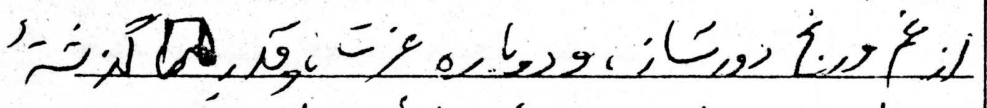
b' (be 3)is) $-6 r-1,6$

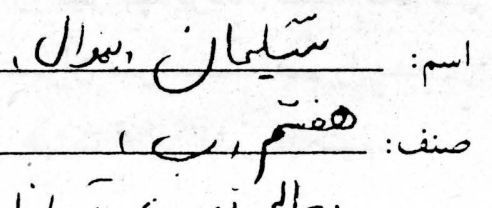
مكتب: i 管

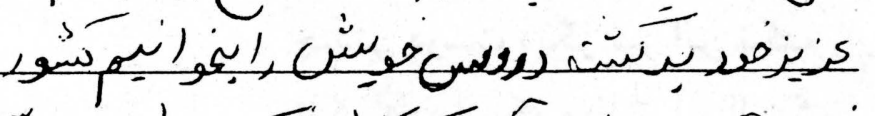
خ, ن هان pilandisecojlis, pls 
خداكند شما مم داراى صحت وسلامتى

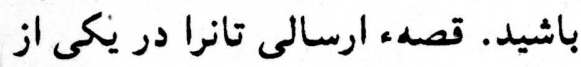

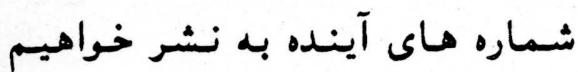
رسانيد. سعادت شما آرزوى ماست. همكار وائى ما نجيب اللّ ساهل! سلام هاى تانرا وعليك ميكوئيسم.

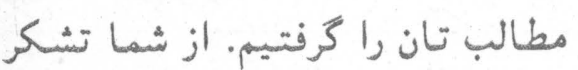

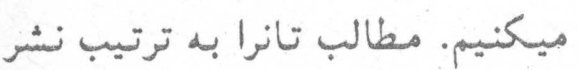

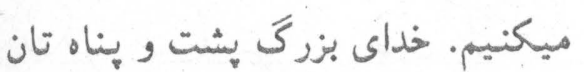
باشد.

\section{* * *}

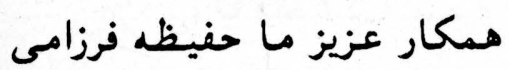

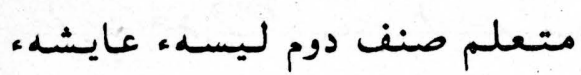
صديقه (رض)! سلام هاى كاركنان مجله را نيز بيذيريد. قصه كلك تان

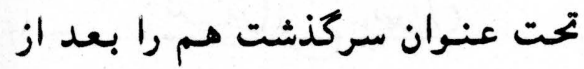
بررسى ميئت تحرير نشر ميكنيم. * * *

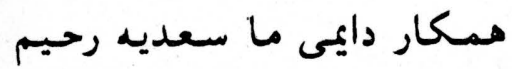

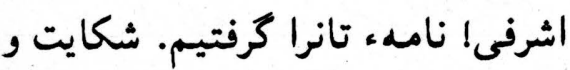

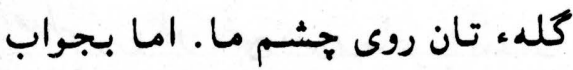
جندتن دوست ديكر نيز اين نكته را رال

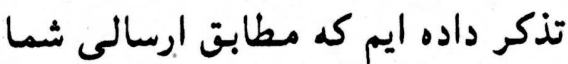
وقتي مطا بتقروحيهء مجله باشدي.

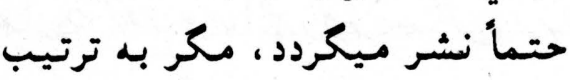

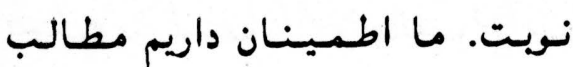

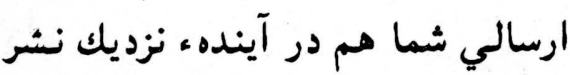
شده و شكايت تـان رفع خواهد شد. منتظر مطالب بهتر از شما هستيبم.

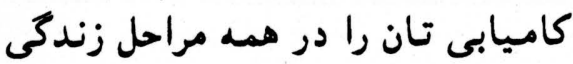
از خداوند متعال ميخواهيم.
رسم هاى تنشُح تان را كرفتيم آنرا نشر ميكنيم. سعادت تانرا از باركاه خداوند مهريان خواهانيم. * * *

مـكار عزيز ما محسمد مارون

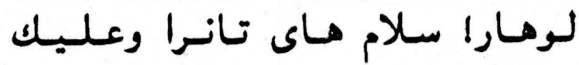
ميكوئيم. ضرب المثل ماى ارسالى فئل

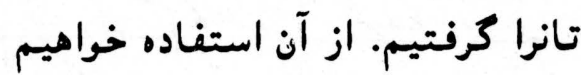

دوستان عزيز و يكدل!

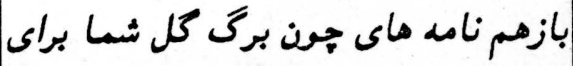

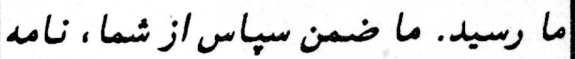

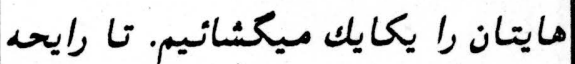
زيباى همكارى و دوستى بيشا يبد شمارا

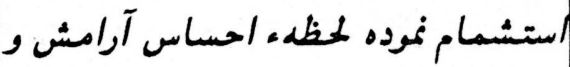

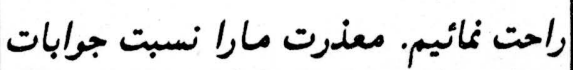
كوتاه نامه هايتان قبول نمائيد.

$$
\begin{aligned}
& \text { كرد ، مؤفق باشيد. } \\
& \text { *** }
\end{aligned}
$$

برادرك گرامى ما احمد ميلاد جان

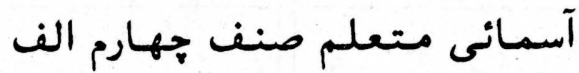

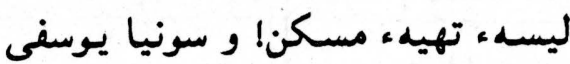
زز تهيه، مسكن كابل! لئل

كاركنان مجله هم خدمت شما

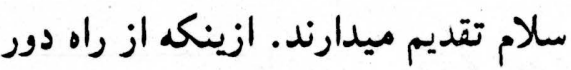

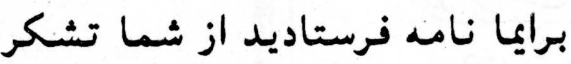
ميكنيم. مطالب ارسالى تان را در

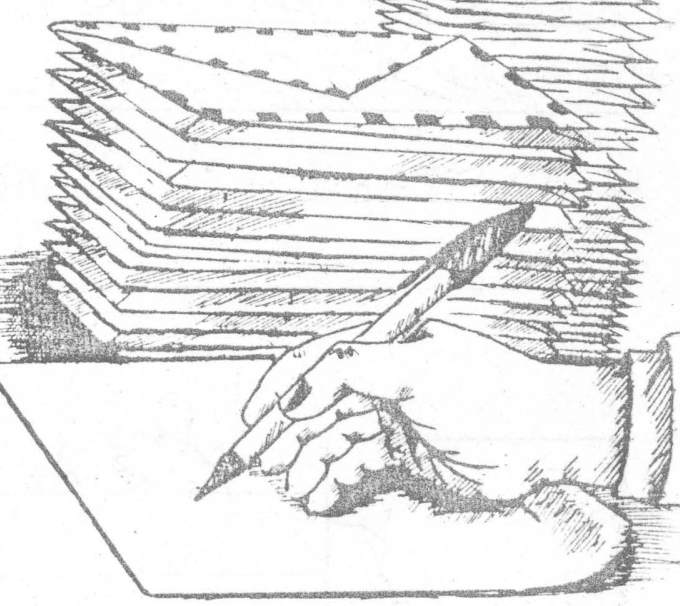

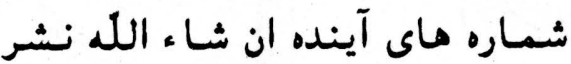
ميكنيم. در يناه خداوند باشيد. * * *

برادر محترم محسمد شفيق * *

فقيرزى!

شـما هم سلام هاى ما را قـبول

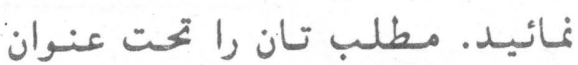
سالمناى 1991 كرفتيهم. از آن استفاده ميكنيم. خداوند يار و مدد"كارتان. ***

ممكار خوب ما ونوس (عارف * * * صديقى) از كارتهء يروان كابل! سلام هاى ما هم تقديم شما باد إن بروان

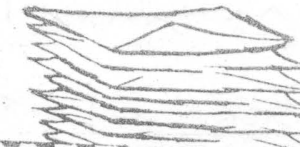

\section{$1=$}


سبرديم. در حفظ خداى تادر و توانا باشيد.

\section{* * *}

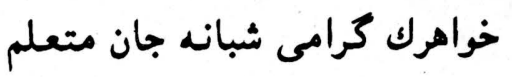
صنف بنجم ليسهء ناهيد شهيد! ما نيز

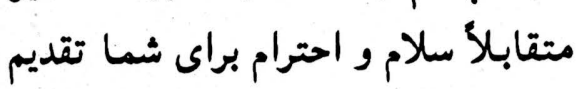
ميداريم. قصهء ارسالى تان را كرفتيم.

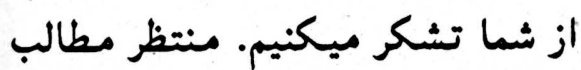
خويتر از شما مستيم. تشكر ميكني.

\section{***}

فهيم جان فاروقى! سلام ماى ما ما

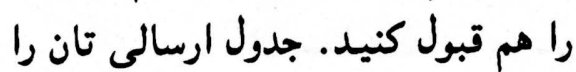

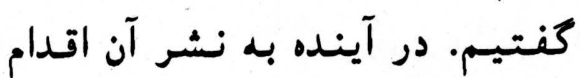
خواهيم كرد. آرامى تان تمناى ماست.

\section{** *}

برادرك عزيـز مـا اركين سعيد متعلم صنف مشتتم مكتب محمبود

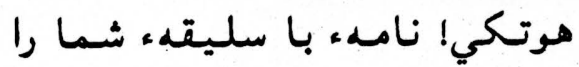

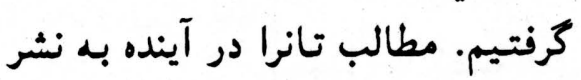
خواهيم رسانيد. مطالب تازه و خوب يني ديكر از شما انتظار داريم.

\section{* * *}

مدكار كرامي عـاليه شنوارى!

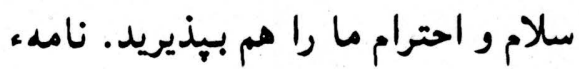
زيباى شما را كرفتيم. از ارسال جدول

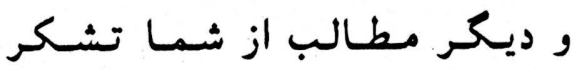

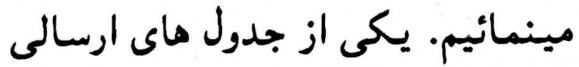
تانرا در ممين شماره كنجانيديم. جشم ائم براه مطالب جالب و خواندنى ديكر از

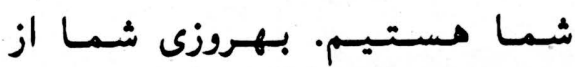
خداوند(ج) استدعا داريم. ** *
***

برادر كرانقدر مـا جاويد احمد * * نائب خيل متعلم ليسه مولانا جلال

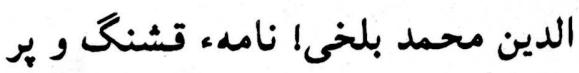
از مطلب شما را كرفتيم. مطالب تانرا

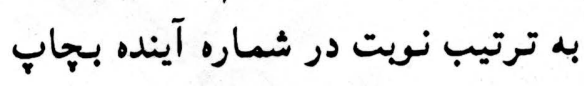
خواهيم رسانيد. خداوند نكهدارتان! *** $*$

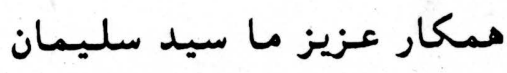
رحيم اشرفى متعلم صنف مشتم ليسه مئه

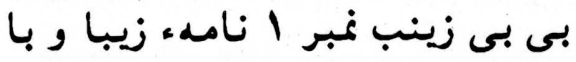

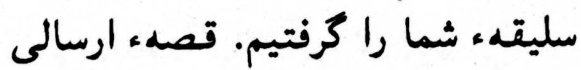

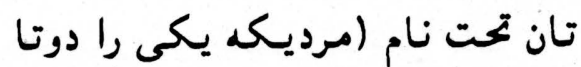

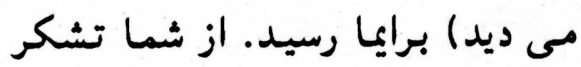
ميكنيم. خداى بزرى به ممراه تان.

* * *

همكار دايمى و فعال ما وجيهه

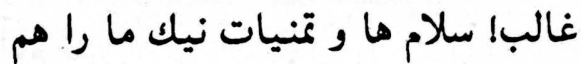

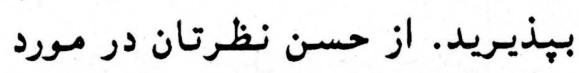
مجله ابراز سياس مينمائيم. مطالب جالب تان برايـا رسيد، ان شاء الله بحاب ميرسد. جشم براه نامه هاى بر از مطالب دلجسب ازشيسا هستيم. سعادتمند باشيد. * * *

خواهرك ما جينا جان متعلم صنف * * * * مانف ششم ليسهء وزيرمحمدكل خان! سلام ماى كاركنان مجله را هم ئم قبول كنيد. دونامه از شما كرفتيسم. تصه كلك تـانرا كه بـراى صفـحهد. مسابقهء تصه نويسى اطفال نوشته جهت بررسى به ميئت تحرير مجله 

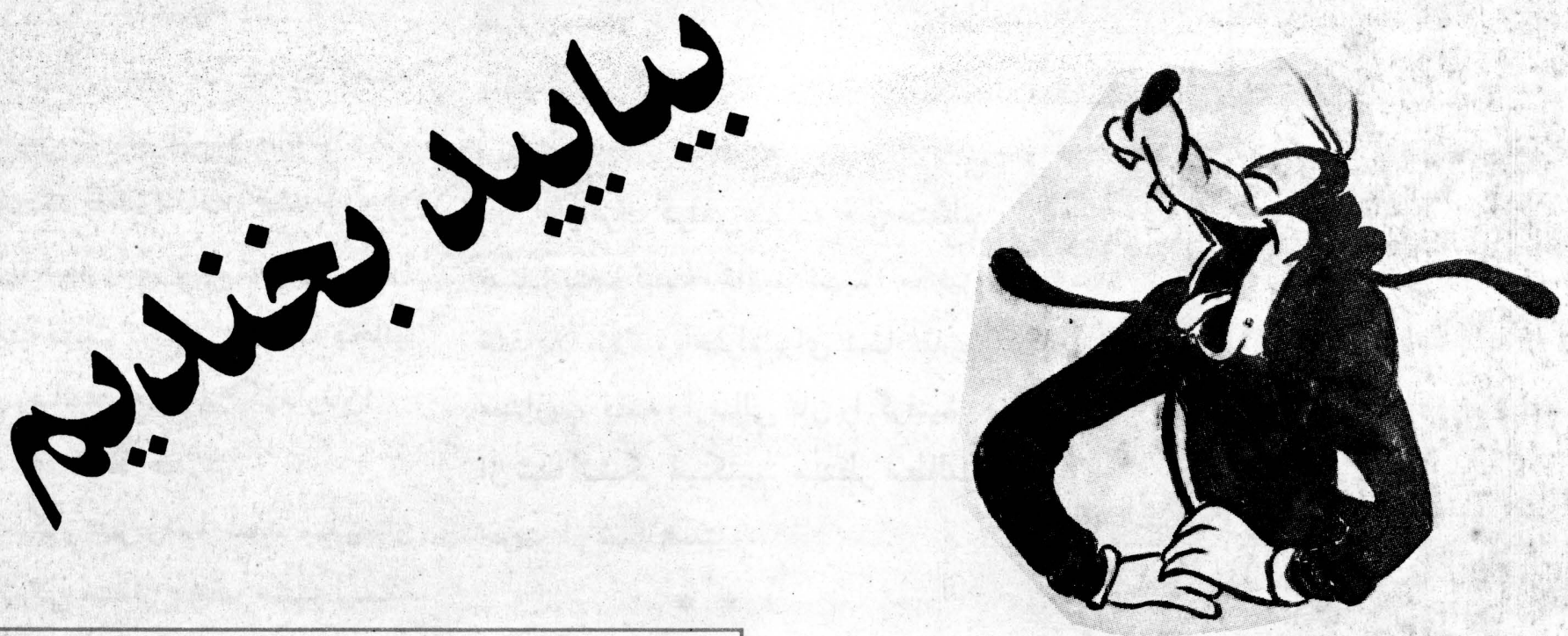

نظافت

معلم نظافت در ساعت درسى نظافت شاكردانرا كنترول مى

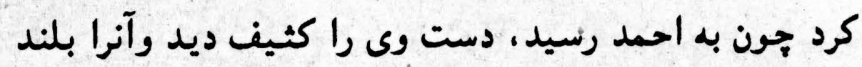

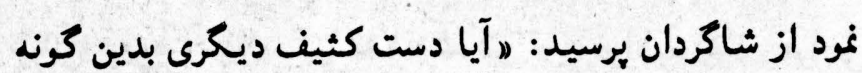

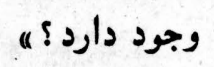

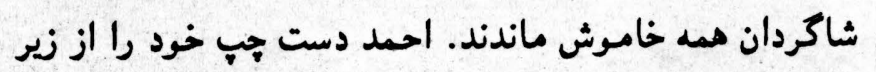

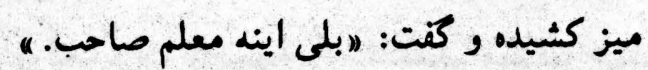

$$
\text { آدم تنبل }
$$

تنببل ها قبه هاي زياد دارند. يك تنبل در سر سرك

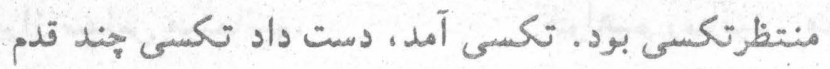

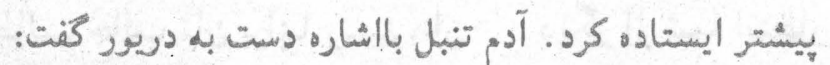

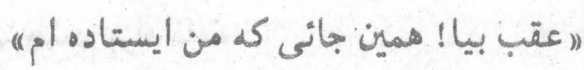

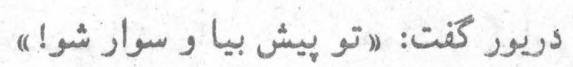

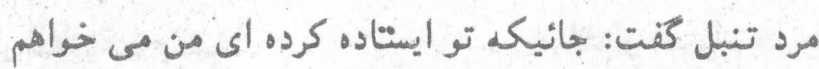

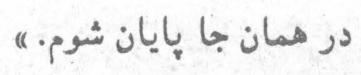

$$
\begin{aligned}
& \text { يُشيماني } \\
& \text { معلم از يك شاخرد صنف أول برسيد: } \\
& \text { دو جمع دو جند ميشود؟ } \\
& \text { جهار }
\end{aligned}
$$

آفرين اين جهار دانه جاكليت را بكير، جايزه ات است.

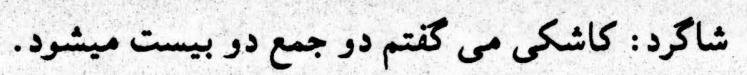

$$
\text { فرشتحانه }
$$

روزى از روز ها مهلم براى شاخردان كفت كه يك جمله براي فرشته بكونيد.

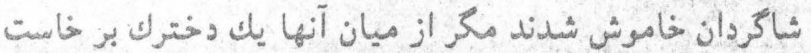

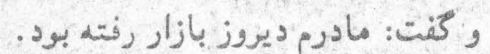

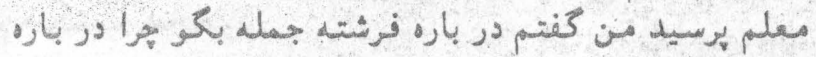

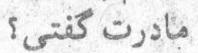
شاكرد معلم را مخاطب قرار داد و كفت: بنخاطرى كه نام مادرم فرشته است.

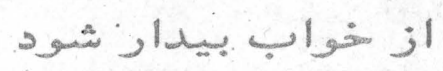

احمد ومحمود ناوقت به مكتب آمدند.

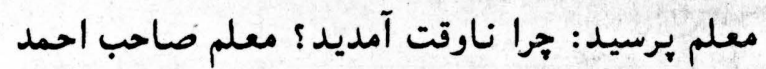

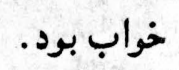

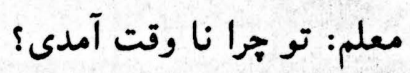
من منتظر شدم تا احمد از خواب بيدار شود.

$$
\text { يإ }
$$

بك نفر كله و هاجه كوسفند را در لب دريا مى شست،

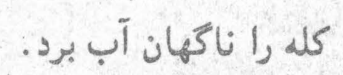

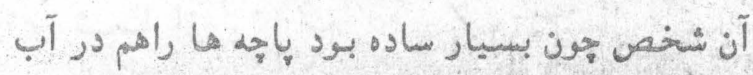

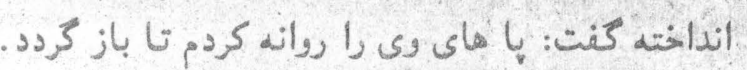




\section{سكاكى او دهغه لنله كيسه}

درنهاخلم.

يوبنتنى وروسته ده هغه جمله داسى ولوستله: " سبيسىوايى داستـاد

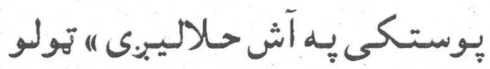

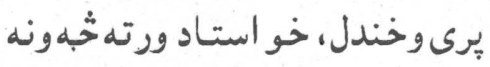
ويل بنده بوره لس كاله خي خُخلوينبت كلنؤزيار ويوست خو سبق يیى زده

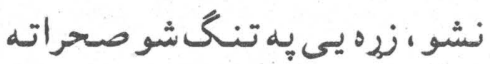

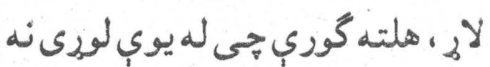

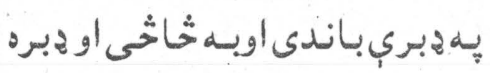
يى كلدى (جقر ) كريده، دهد لهئهانه

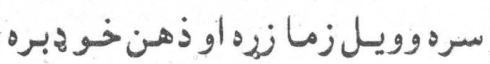

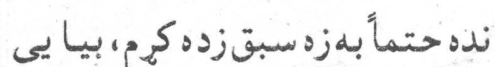
كلك تصميمونيو او بيرته بنبارته راغى او يـهُخلوينبت كلنى عمر يیى

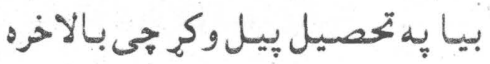
دكلك تصميم او ثابت عزم له منخى

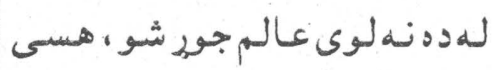

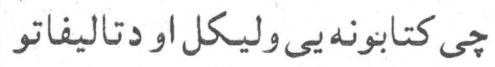

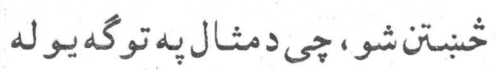
تالبفاتوخخه يسى مفتـاح العلوم نوميب:ى.

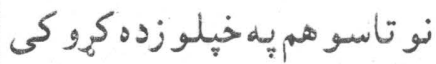

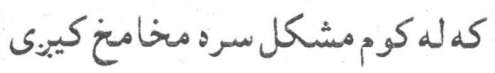
نو استقامت له لاسه مهوركوى ،مرو مـ د د باليتوب ستاسو پيهبرخهدئ.

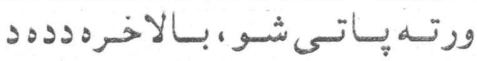

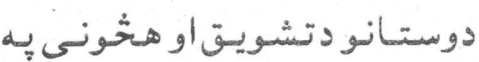
اساس سكاكى خيل هنر يعنى جون كيى صنـدوق دخوارزمشـاهـانسو دربارتهدننداري ليارهوراندى كي ،

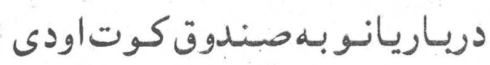

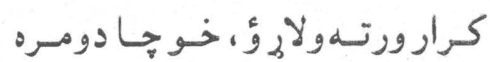
جندانى يامنهورته ساتهدا شيبه كه

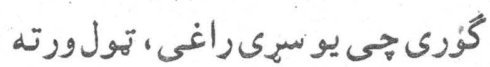

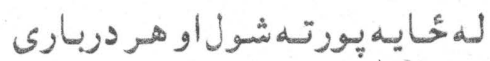

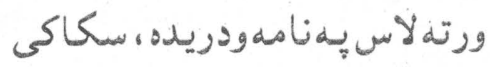

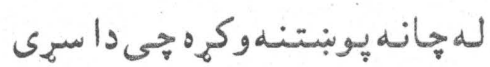
خو خؤ ، هغه وزته وويل جى هغنه يو

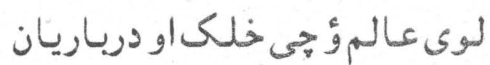
ورتهلاس بدنامهنودريدل. سكاكى يه خيل تحان تاسف وكية او ارمسان يسى وكي تجى ولى ترديرش

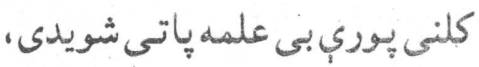
بالاخره يیى تحصيل ته ملاوتئله، خو حُنو بهورتهوويل جى يهدي يسن كى تهنشسى كولاى جيى تحصيل وكي.

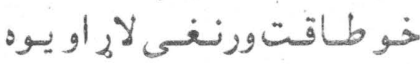

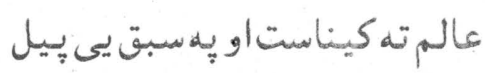

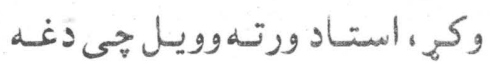

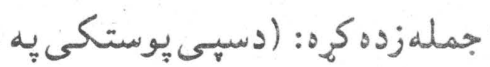
آش حلاليي.ى) او سبا يوبنتـنه درنه كوم يعنى دهمدغى جملى امتحان
خوز ومـاشومـانسو او زره تسهرا نزدي زده كوونكو! خركُنده خبره

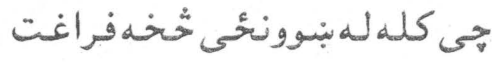

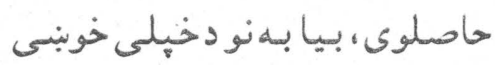

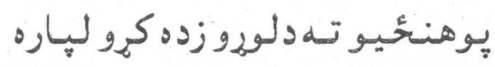

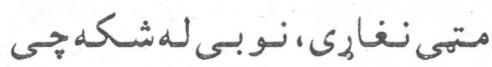

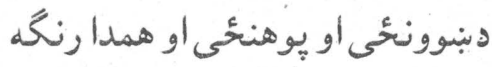
دزوند يهنورو حارو كي به خامخا له

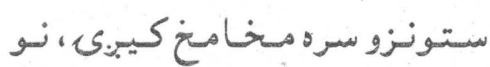

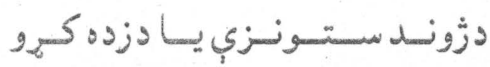

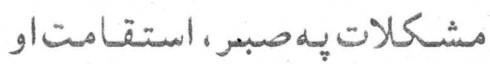

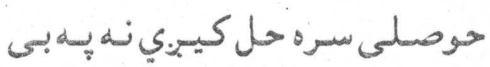

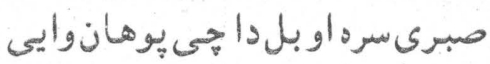

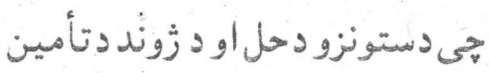

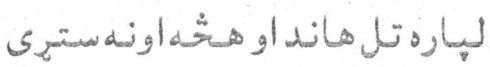

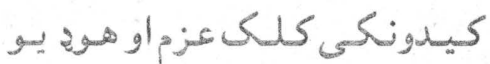

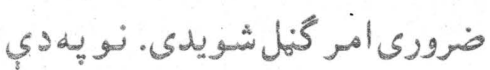

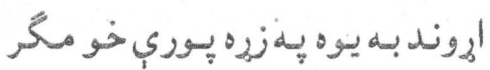
جيرى لندي كيسى ته هيى ديوه تكره عالم يهـ هكله ليكل شوى ستاسو

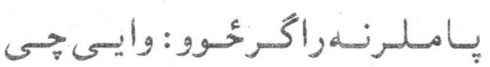
سكاكى يسه لـو مـرى سمركى يسبن

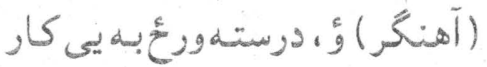
كاوهاو خولى بـهيرى راماتى وئدي،

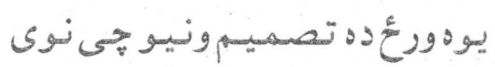

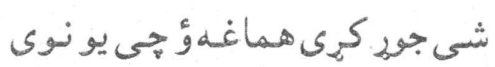

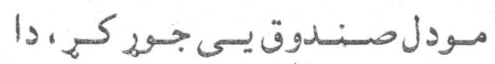
صندوق به هي هر حا وليد حيران به 


\section{رنكين كان}

نيوتن عالم بزرگ انحليسى كه قوه جاذبه را كشف كرد، قرار نظريه او نظم ستارخان دركائنات بواسطه قوه جاذبه

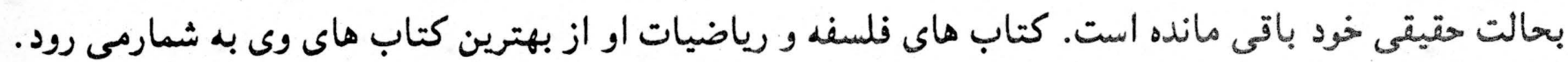

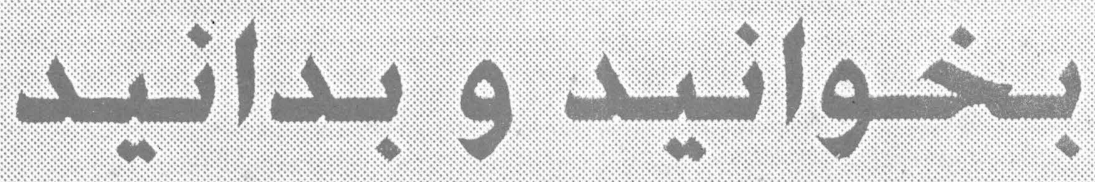

\section{يك تقويم عالى و حيرت انكيز}

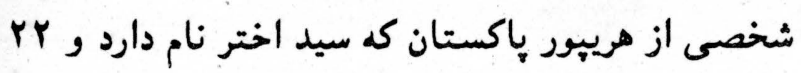

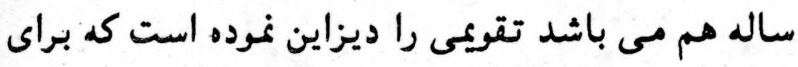

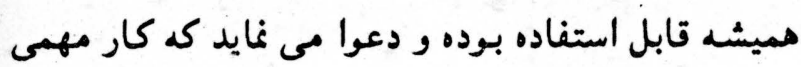

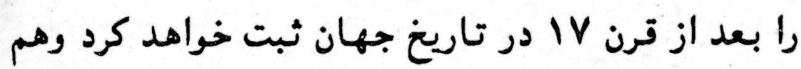

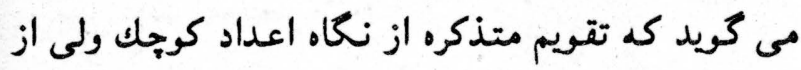

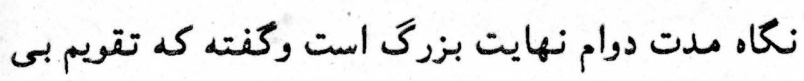
نهايت (لايتناهى) او كه بعد از كار دوامدار تكميل

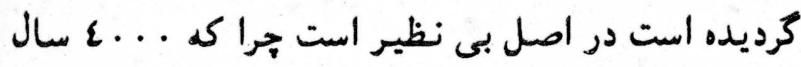

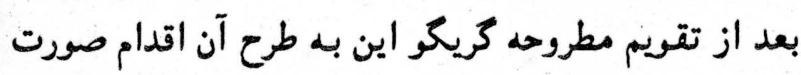

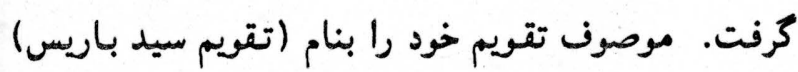
ياد كرده است و كنته كه اين جنترى مطروحه او ميليون و

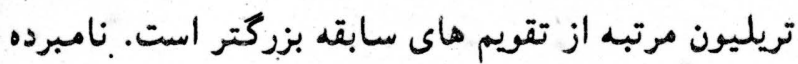

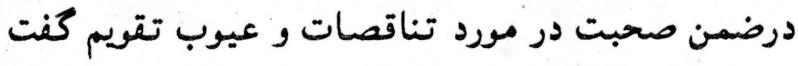

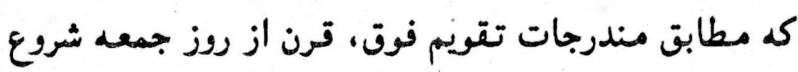

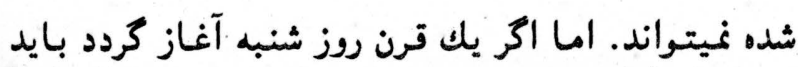
روز بنجشنبه ختم شود كة در ينصورت قرن بعدى بطور

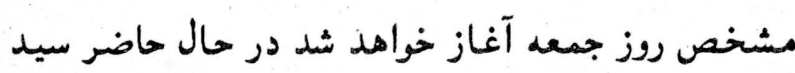
روى تنظيم تقويم هجرى كار ميكند كه البته اختلافات

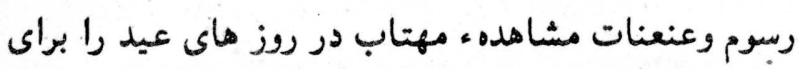

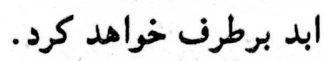

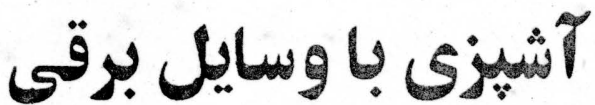

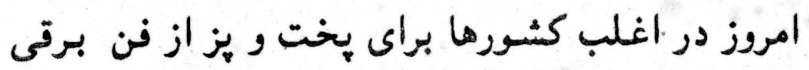

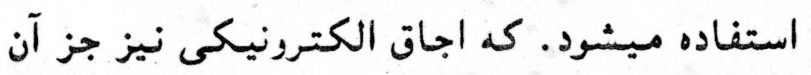

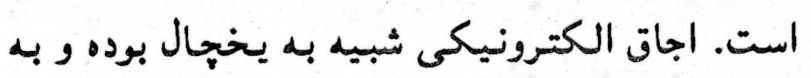

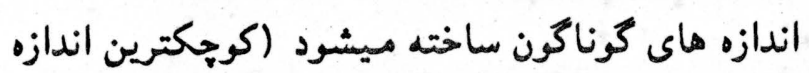

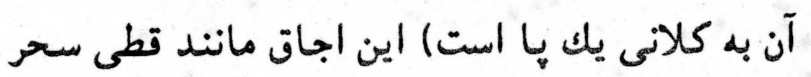

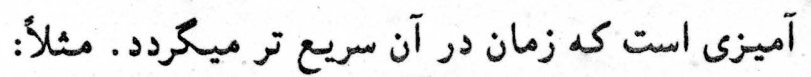

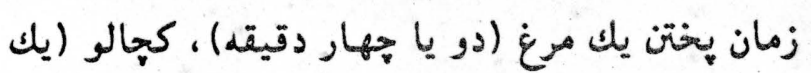

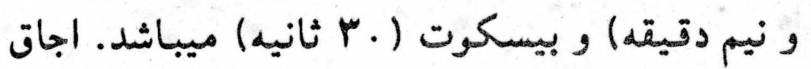

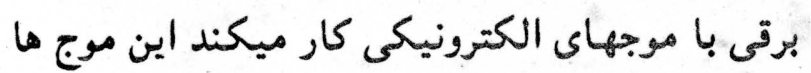

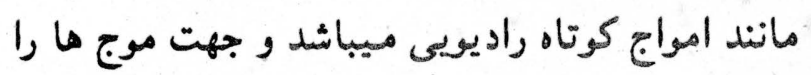
ور يك ثانيه ميليونها بار تغيير ميدهند. همرينين

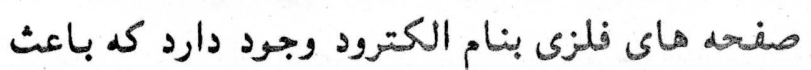

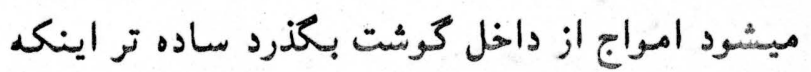

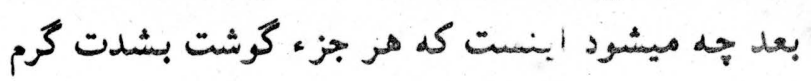

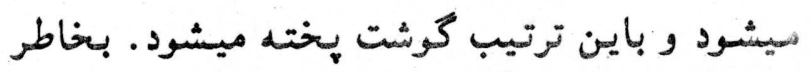

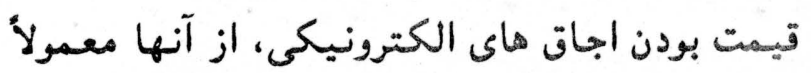

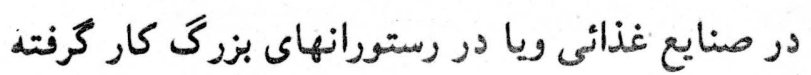

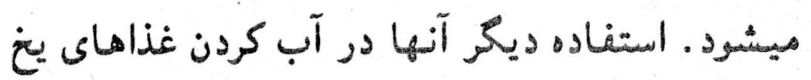

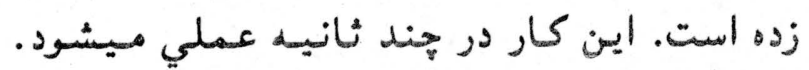

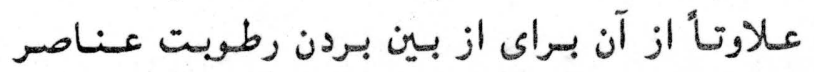

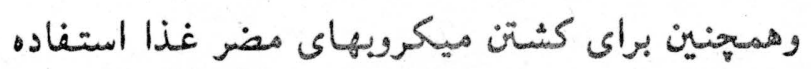
ارسالى وجيهه غالب

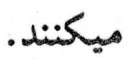



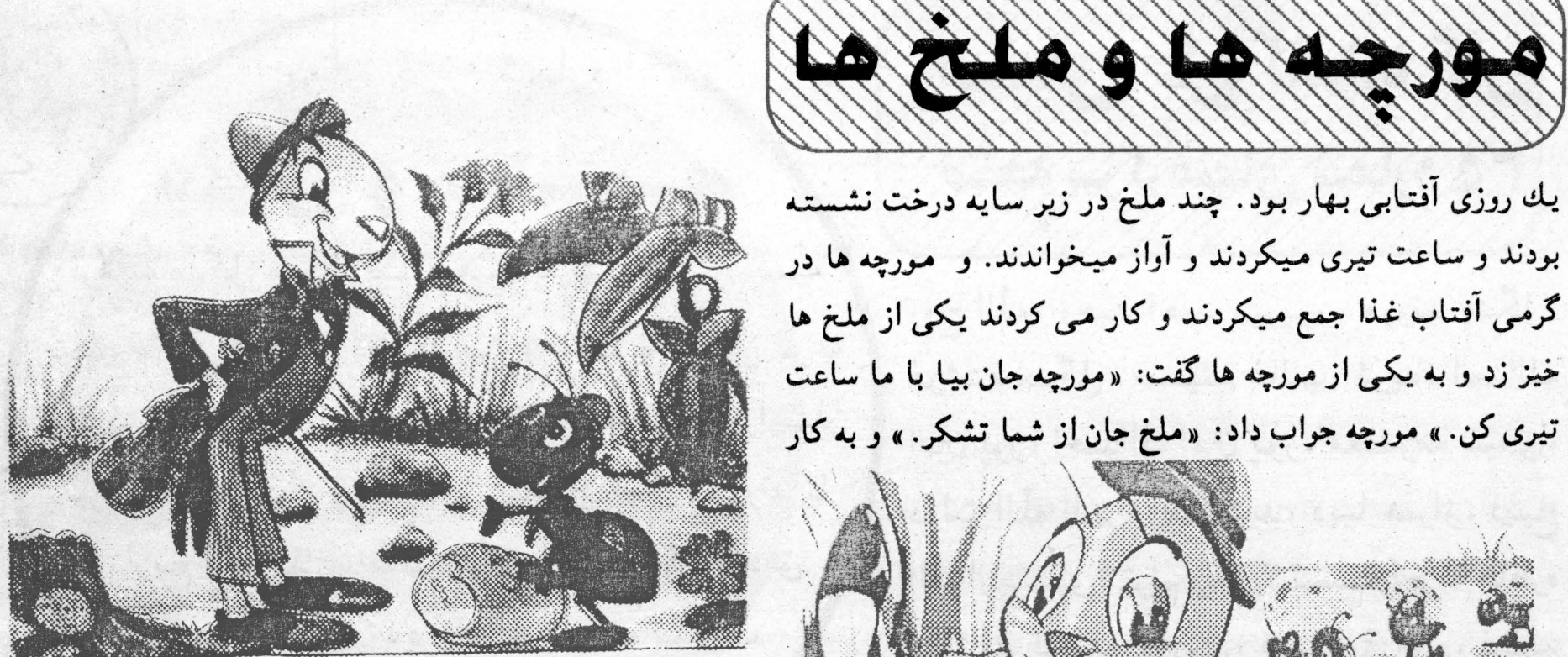

هم خورده بود خانه همان مورجه را كه در تابستان بالايش خنده

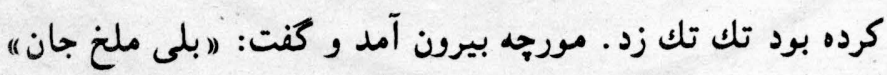

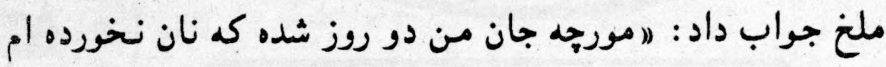

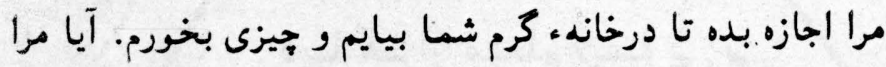

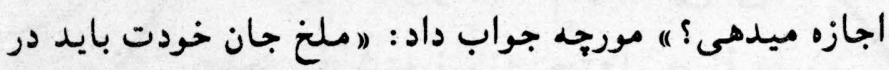

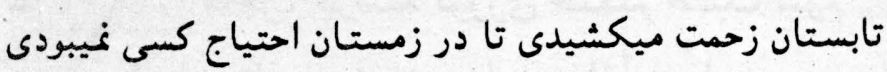

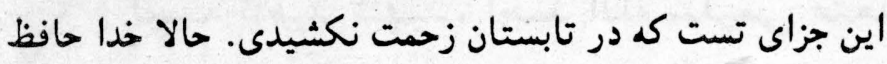

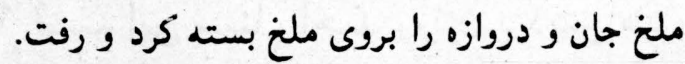

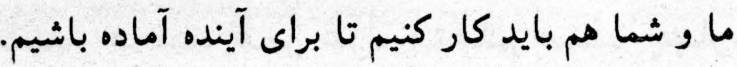

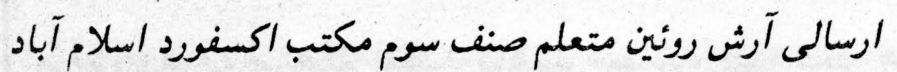

يك روزى آفتابى بهار بود. جند ملخ در زير سايه درخت نشسته

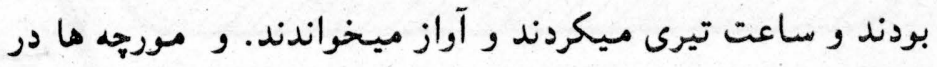

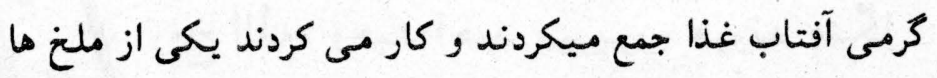

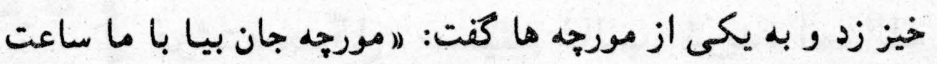

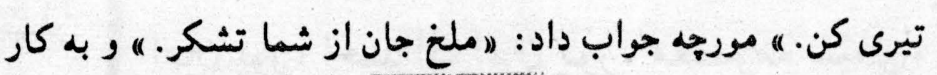

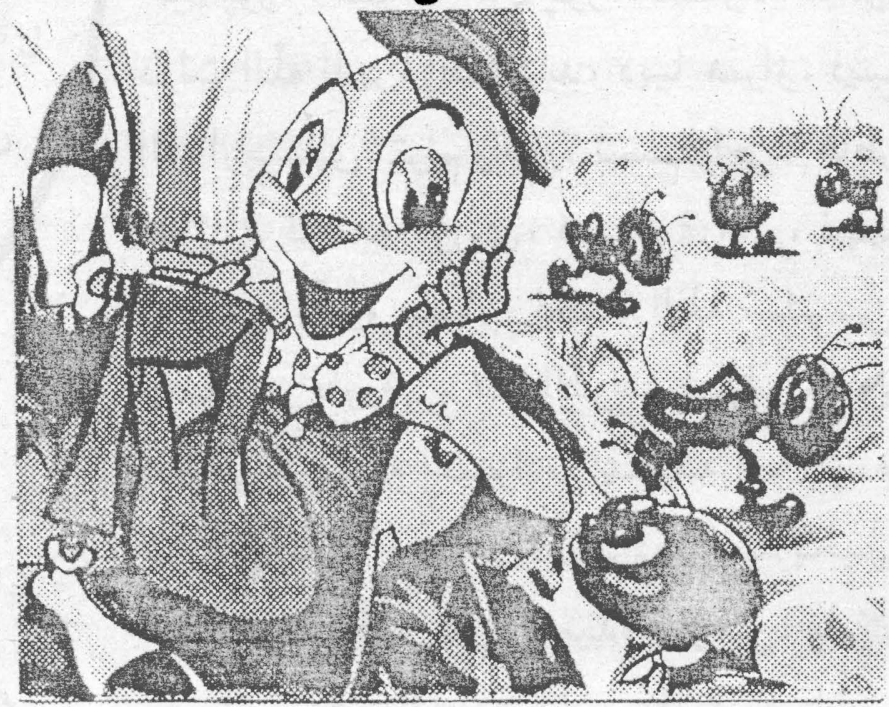

خود ادامه داد. ملخ كفت: "بيجاره! )، و رفت مورجه ها بسيار

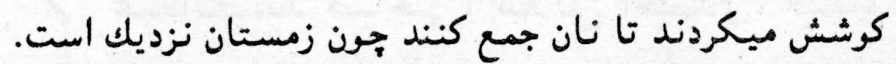

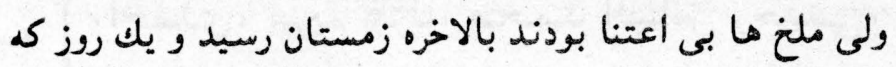

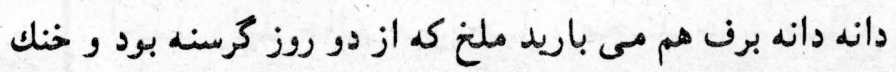

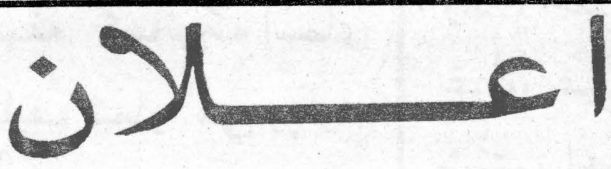

مزده به علاقمندان آموزش هنر:

انستيتيوت هنر هاى زيباى غلام محسد ميمنكى براي كورسهاى رسامى ينسلى، نقاشى رنگ آبى، نقاشي رنگ روغنى، خطاطى و ميناتور شاكردان اناث و ذكور رامى بذيرد. تحت نظر استادان و هنرمندان ورزيده.

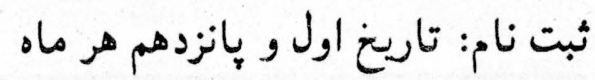
در ختم دوره آموزشى شهادتنامه اعطا ميكردد.

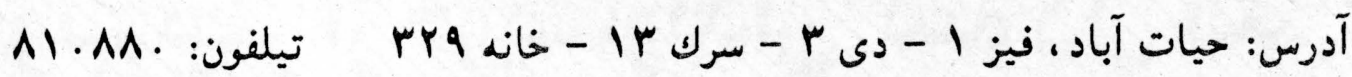


(26) Irvv سال سوم شماره سى وهنتم سنبله

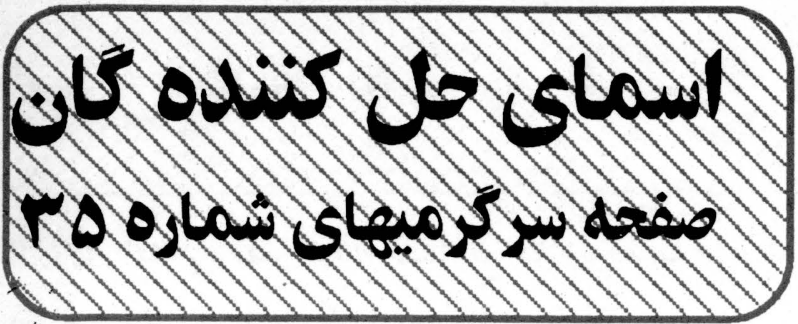

روح الله، وحيد احمد ميريور، ميوند منكل، فرشته منحل، حسينه غالب، نويد، اسدالله

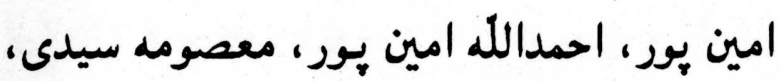

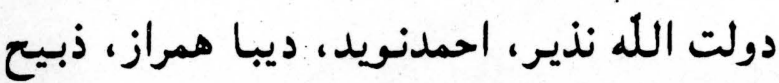

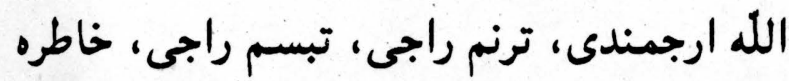

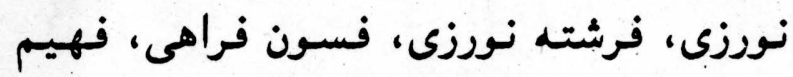

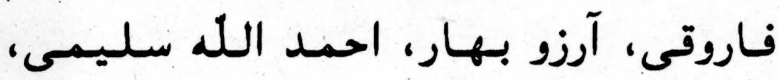

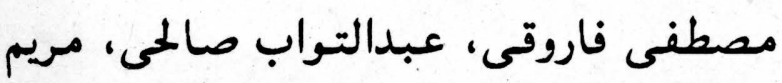

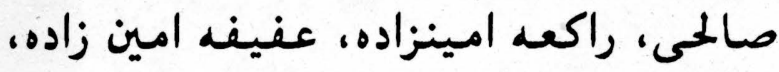
سارا صالحى، احمد روئين برديس ميريخيل،

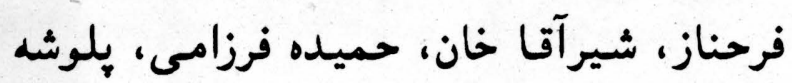

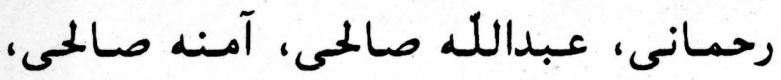

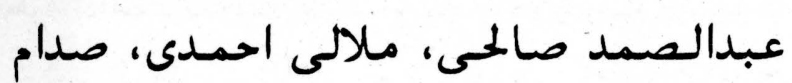

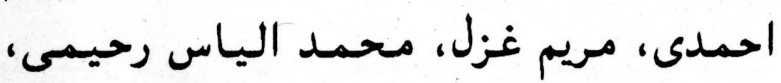

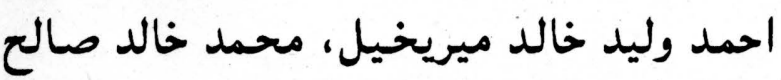

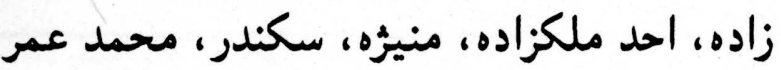

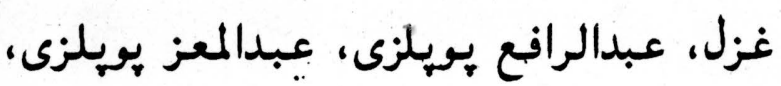

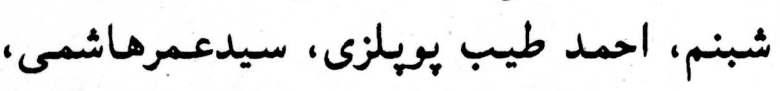

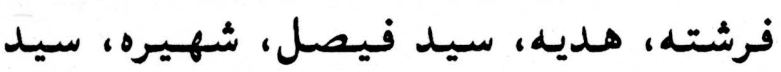

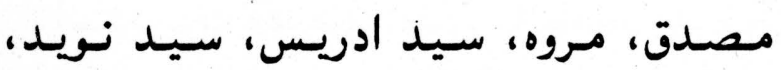

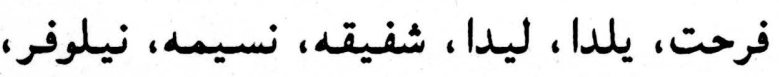

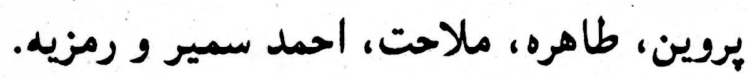

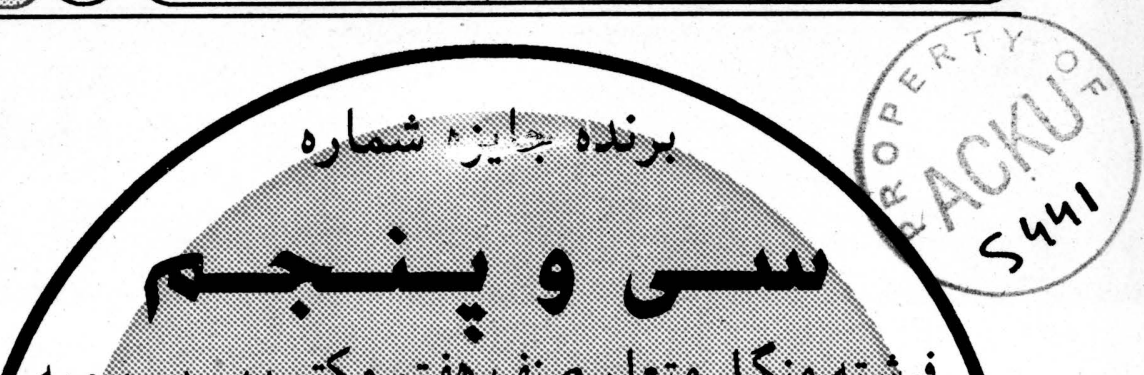

ف ب. شأl G

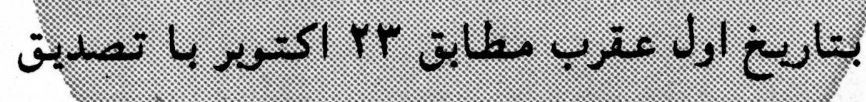
S.

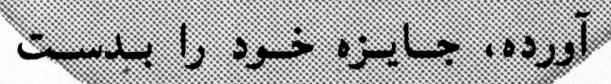

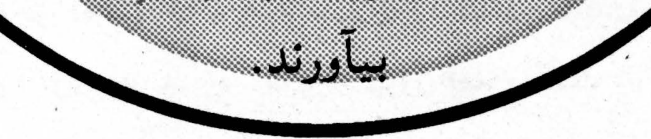

10 IAIC هاجر، فرشته نورزى متعلم صنف سوم ليسه ناهيد شهيد، احمد الله سليمى متعلم لورئم

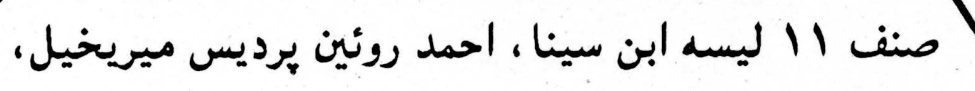

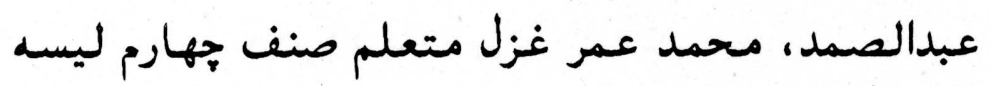

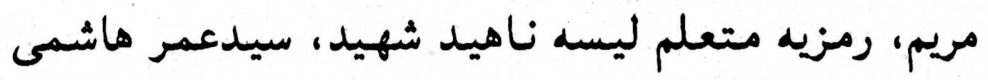
متعلم صنف جهارم ليسه وطن و شفيقه. كسانيكه اسماى رئي

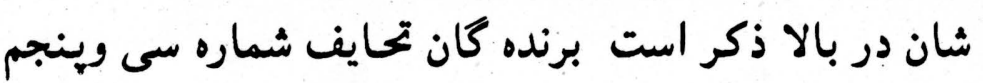

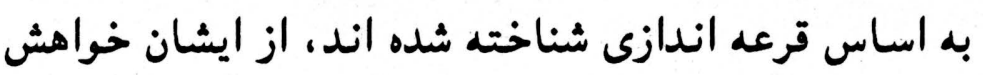

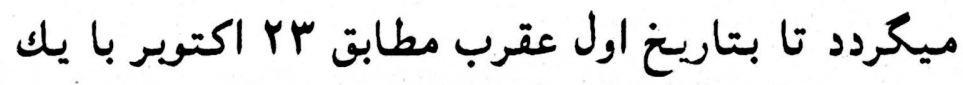
قطعه عكس و تصديق مكتب بـ اداره مجله رنكين كمان تشريف آورده تحايف خود را بلدست بيآورند. 


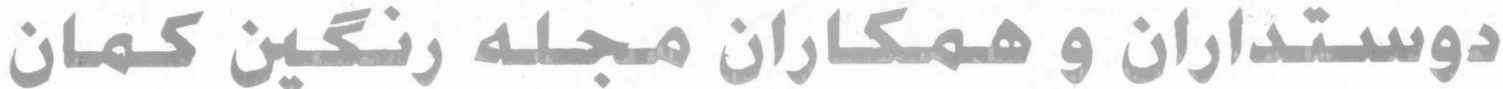

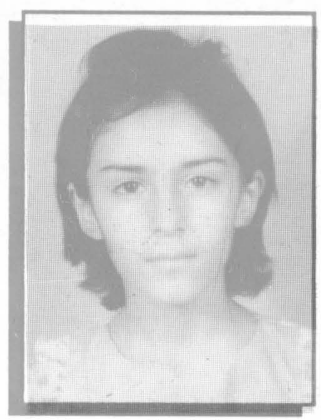

سلوا جان

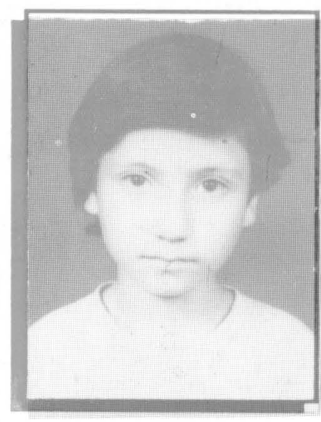

بلوشه جان

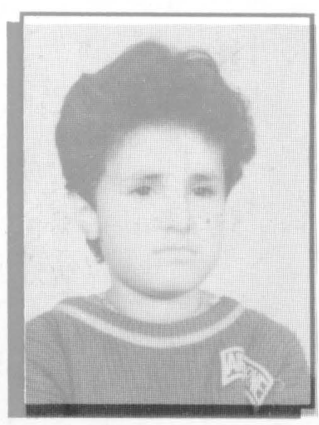

مريم جان

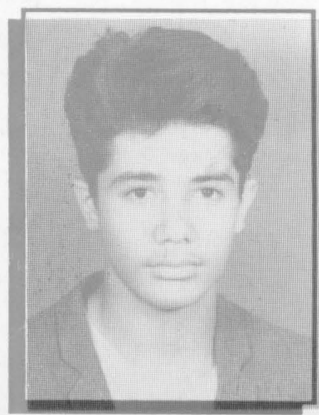

امان الله رينجا

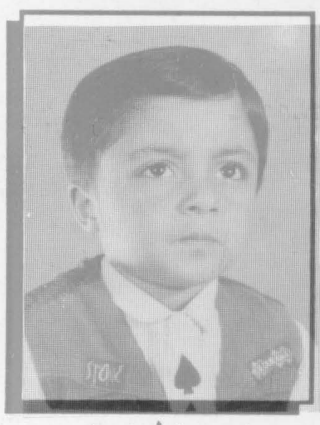

احمديلال فرملى

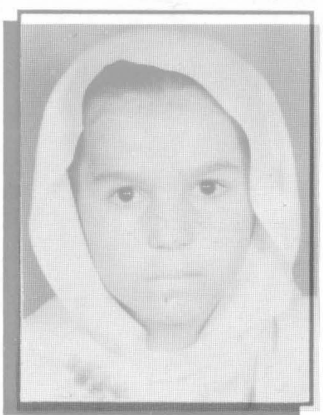

شيلا شاهى

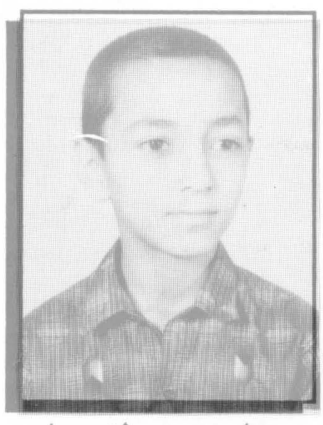

احمد مصطفى جان

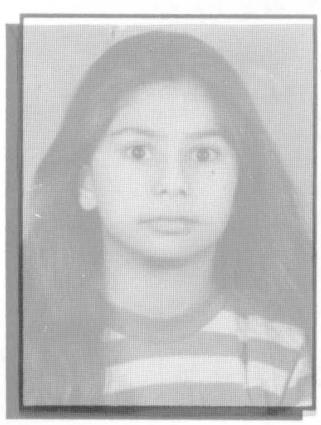

فرشته جان

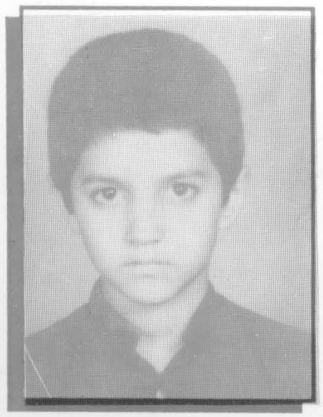

بلال عسكرزاده

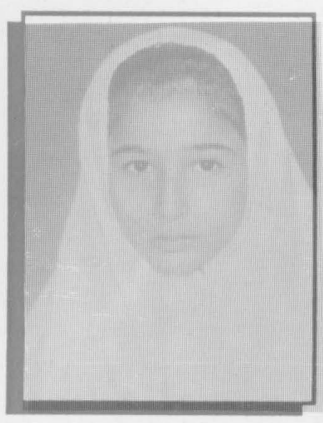

حسنى تارى زاده.
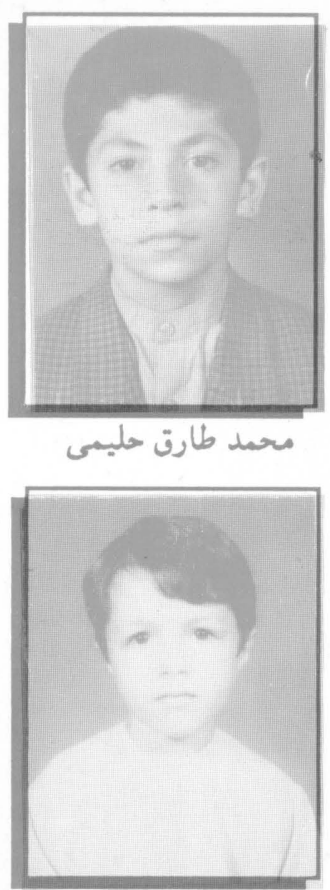

محمد ضميرجان

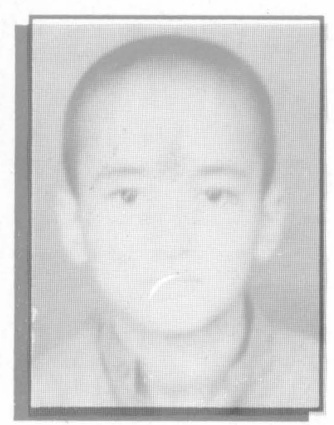

سيدمشتات احمد جان

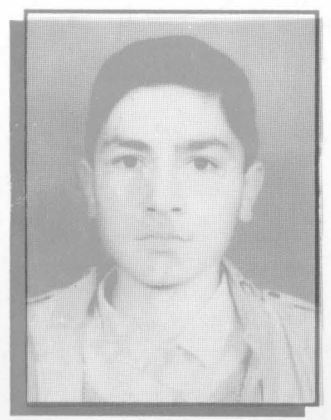

ضباء الله جان

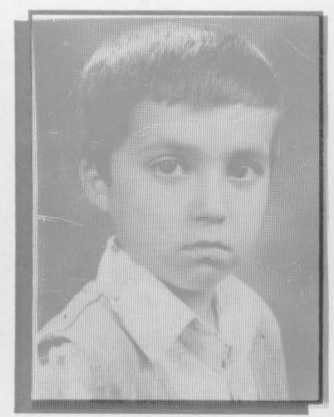

داريوش جان

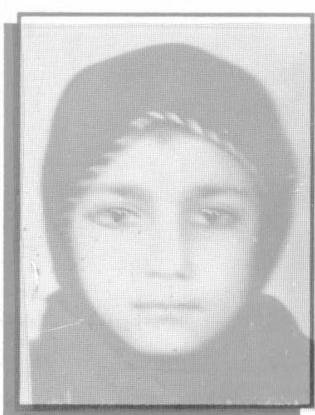

فريحه جان

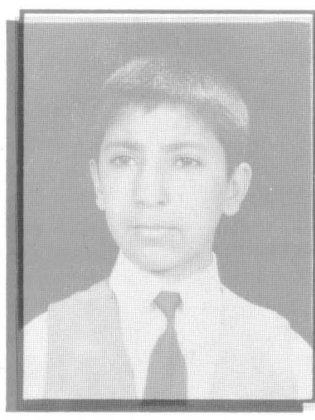

احد سهيل جان

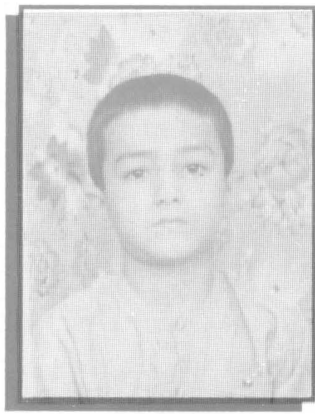

سيدثنار احمد جان

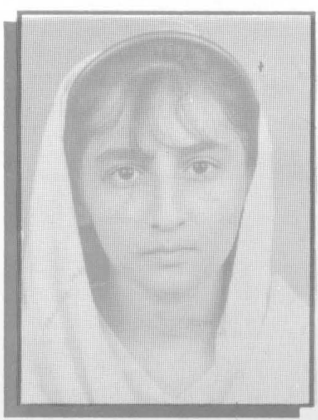

سيلى جان

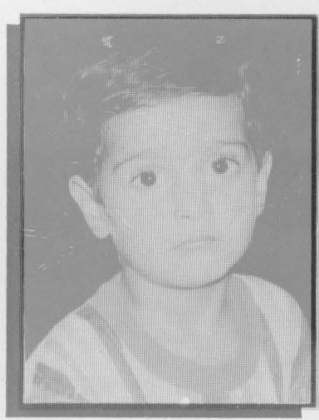

حميد جان

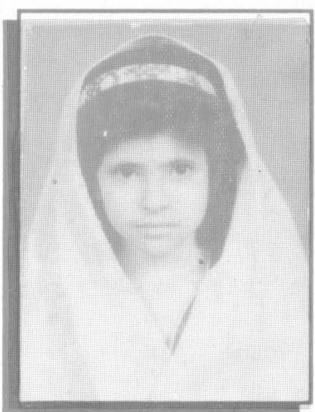

شفيقه جان

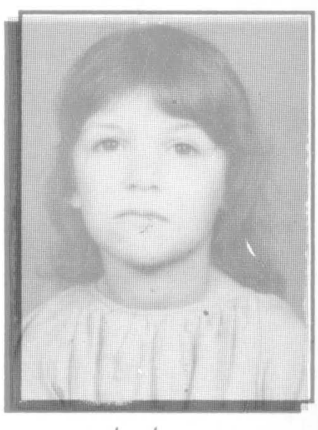

سوريا جان

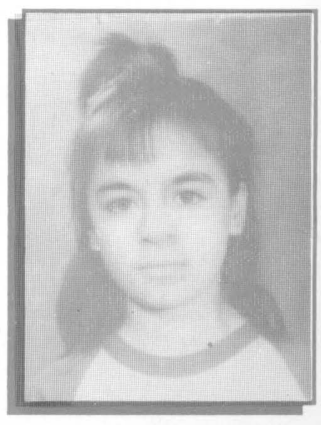

اسماء جان

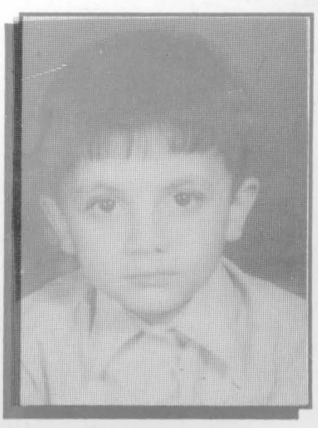

وفى الرحمن وليد

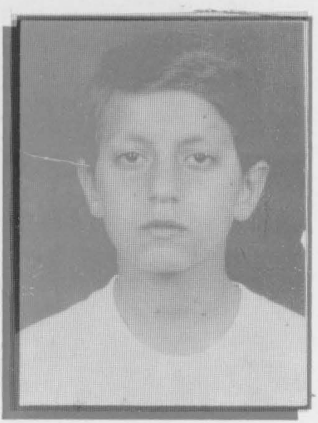

محمد هارون جان 
